GUILHERME GOMES SILVEIRA

\title{
MODULAÇÃO DA APRESENTAÇÃO ANTIGÊNICA POR CÉLULAS DENDRÍTICAS DERIVADAS DE MONÓCITOS UTILIZANDO DIFERENTES PRODUTOS VIRAIS DO HIV: potencial de utilização em vacina terapêutica
}

Dissertação apresentada ao Instituto de Ciências Biomédicas da Universidade de São Paulo para obtenção do Título de Mestre em Ciências (Imunologia)

São Paulo 2010 
GUILHERME GOMES SILVEIRA

\section{MODULAÇÃO DA APRESENTAÇÃO ANTIGÊNICA POR CÉLULAS DENDRÍTICAS DERIVADAS DE MONÓCITOS UTILIZANDO DIFERENTES PRODUTOS VIRAIS DO HIV:}

potencial de utilização em vacina terapêutica

Dissertação apresentada ao Instituto de Ciências Biomédicas da Universidade de São Paulo para obtenção do Título de Mestre em Ciências (Imunologia)

Área de Concentração: Imunologia

Orientador: Prof. Dr. Gil Benard

São Paulo

2010 
DADOS DE CATALOGAÇÃO NA PUBLICAÇÃO (CIP)

Serviço de Biblioteca e Informação Biomédica do

Instituto de Ciências Biomédicas da Universidade de São Paulo

(C) reprodução total

Silveira, Guilherme Gomes.

Modulação da apresentacão antigênica por células dendríticas derivadas de monócitos utilizando diferentes produtos virais do HIV: potencial de utilização em vacina terapêutica / Guilherme Gomes Silveira. -- São Paulo, 2010.

Orientador: Gil Benard.

Dissertação (Mestrado) - Universidade de São Paulo. Instituto de Ciências Biomédicas. Departamento de Imunologia. Área de concentração: Imunologia. Linha de pesquisa: Vacina anti-HIV.

Versão do título para o inglês: Modulation of monocyte-derived dendritic cell antigen presentation using different HIV antigenic: potential use in therapeutic vaccine.

Descritores: 1. Vacinas 2. HIV 3. Células dendríticas 4. Antígenos de vírus 5. Vetores virais I. Benard, Gil II. Universidade de São Paulo. Instituto de Ciências Biomédicas. Programa de Pós Graduação em Imunologia III. Título. 
UNIVERSIDADE DE SÃO PAULO

INSTITUTO DE CIÊNCIAS BIOMÉDICAS

\begin{abstract}
Candidato(a):
Guilherme Gomes Silveira.

Título da Dissertação: $\quad$ Modulação da apresentação antigênica por células dendríticas derivadas de monócitos utilizando diferentes produtos virais do HIV: potencial de utilização em vacina terapêutica.
\end{abstract}
Orientador(a):
Gil Benard.
A Comissão Julgadora dos trabalhos de Defesa da Dissertação de Mestrado, em sessão pública realizada a ...............

\title{
( ) Aprovado(a) \\ ( ) Reprovado(a)
}

$\begin{array}{ll}\text { Examinador(a): } & \begin{array}{l}\text { Assinatura: } \\ \text { Nome: } \ldots \ldots \ldots \ldots \ldots \ldots\end{array} \\ & \text { Instituição: } \\ \text { Examinador(a): } & \text { Assinatura: } \\ & \text { Nome: } \\ & \text { Instituição: } \\ & \text { Assinatura: } \\ & \text { Nome: } \\ & \text { Instituição: }\end{array}$ 
São Paulo, 04 de maio de 2009

\section{PARECER 890/CEP}

Prezado Senhor,

Atendendo sua solicitação, a Comissão de Ética em Pesquisas com Seres Humanos do ICB, em sua $94^{\text {a }}$ reunião realizada em 30.004.09, analisou o projeto de sua responsabilidade intitulado: "Modulação da apresentação antigênica por células dendríticas derivadas de monócitos humanos utilizando diferentes produtos virais do HIV: potencial de utilização em vacina terapêutica".

Informo a V.Sa. que, após análise e discussão, o referido projeto foi aprovado por esta Comissão.

Lembramos que cabe ao pesquisador elaborar e apresentar a este Comitê, relatórios anuais (parciais ou final), de acordo com a resolução 196/06 do Conselho Nacional da Saúde, item IX.2 letra c.

O primeiro relatório deverá ser encaminhado à Secretaria deste CEP em $\mathbf{3 0}$ de abril de 2010 .

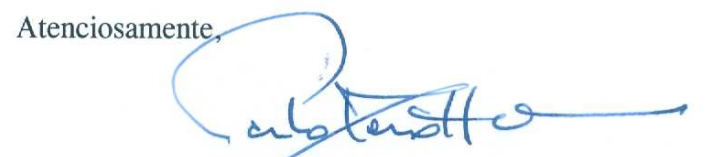

Prof. Dr. Paolo M.A ZanotTo

Vice-Coordenador da Comissão de Ética em Pesquisas com Seres Humanos - ICB/USP

Ilmo Sr.

GUILHERME GOMES SILVEIRA

Departamento de Imunologia

Instituto de Ciências Biomédicas -USP

Comissão de Ética em Pesquisa com Seres Humanos do Instituto de Ciências Biomédicas / USP Aprovada pela Comissão Nacional de Ética em Pesquisa - CONEP, em 10 de fevereiro de 1998. 
Dedico este trabalho em memória ao meu irmão Lucas Gomes Silveira e à minha mãe Sonia Maria Gomes Silveira, pois, infelizmente, não puderam vê-lo concretizado pessoalmente. 


\section{AGRADECIMENTOS}

À Deus, pelo dom da Vida, pela liberdade e por todos os momentos felizes e tristes da minha vida.

Ao meu pai Claudemiro Silveira, por todo amor, apoio, ensinamentos, amizade e paciência. Ao meu irmão Lucas Gomes Silveira e minha mãe Sonia Maria Gomes, por zelarem por mim a todo instante.

À minha noiva Paula Marcato, por todo amor, apoio e ajuda nos momentos difíceis. Você é minha inspiração, fortaleza e alegria, um presente de Deus na minha vida. Obrigado por todos os momentos de convivência, alegria, felicidades, tristezas, desentendimentos, nervosismo e conquista. Que nossa união seja para sempre.

Ao Prof. Dr. Alberto José da Silva Duarte, pela oportunidade e estrutura concedidas para o desenvolvimento deste projeto no LIM-56.

Ao Prof. Dr. Gil Benard, pela oportunidade e confiança, pela inspiração e inestimável orientação, pela amizade e, principalmente, por sua paciência comigo.

À Dr. Telma Miyuki Oshiro, pela oportunidade, confiança em mim e inestimável ajuda sempre que precisei, sem a qual, com certeza, esse trabalho não teria sido realizado.

À Dra. Érika Fujihira, por toda ajuda neste projeto, principalmente na parte de biologia molecular, sem esquecer, é claro, das muitas risadas.

Aos amigos dos dois grupos de pesquisa que faço parte: Dra. Camila Cácere, Léia Cristina Rodrigues da Silva, Vanessa Gomes Batista e Maria de Lourdes Palermo Neves, e Rafael Martins Oliveira, Cláudia Finazzo, Alexandre de Almeida e Laís Teodoro da Silva, pela ótima convivência e muitas risadas, por toda colaboração e ajuda nos experimentos e por todo aprendizado em muitas discussões científicas.

A todos os amigos e colegas do LIM-56 que me ajudaram direta ou indiretamente na realização deste estudo, em especial aos amigos Cyro Alves de Brito, Liã Bárbara Arruda, Soraya Ogusuku Ferraz, Juliana Cristina dos Santos e Paula Rigato, pela amizade e companheirismo. 
Ao amigo Rodrigo Gomes de Oliveira, pelo desenvolvimento e diagramação de praticamente todas as imagens presentes nessa dissertação.

Ao amigo Demétrius Vignati Alves da Silva, por toda ajuda de computação, nos hardwares e softwares utilizados direta ou indiretamente na realização deste projeto.

A todos os funcionários do LIM56, pelo suporte e amparo fundamentais em todos os momentos que necessitei: Edna dos Reis, Juliana Pisok, Ângelo Barbosa, Luiz Carlos Abrahão, Adriana Costa, Lúcio Martins, Anderson Prado, Adriana Santana, Sílvia Castro e Eduardo Martins.

À Olivete Ribeiro Venâncio, ex-secretária do LIM56, meus sinceros agradecimentos por ter me levado a FAPESP, faltando apenas 5 minutos para 0 encerramento do prazo para solicitação de bolsas de Mestrado.

Aos pacientes, pares discordantes e controles que, voluntariamente e sem nenhum tipo de bonificação, participaram deste projeto, os meus sinceros e especiais agradecimentos.

À Fundação de Amparo a Pesquisa do Estado de São Paulo (FAPESP) e ao Programa Nacional DST/AIDS do Ministério da Saúde pelo apoio financeiro no desenvolvimento deste projeto. 


\section{CULTURA E SABEDORIA}

Cultura

é ensinar ao menino a ler e a escrever palavras

Sabedoria

é ensinar-lhe a vivenciar sentidos

Cultura

é ensinar-lhe sobre as coisas da natureza

Sabedoria

é ensinar-lhe sobre a natureza das coisas

Cultura

é ensinar ao menino a ver as horas

Sabedoria

é ensinar-lhe a aproveitar seu tempo

Cultura

é ensinar-lhe os atalhos do poder

Sabedoria

é ensinar-lhe os longos caminhos da liberdade

Cultura

é ensinar ao menino a somar riquezas

e a diminuir custos

Sabedoria

é ensinar-lhe a multiplicação das virtudes

e a divisão por amor

Cultura

é ensinar-lhe a trabalhar o corpo

Sabedoria

é ensinar-lhe a salvar a alma 


\section{RESUMO}

SILVEIRA, G. G. Modulação da apresentação antigênica por células dendríticas derivadas de monócitos utilizando diferentes produtos virais do HIV: potencial de utilização em vacina terapêutica. [Dissertação]. São Paulo: Instituto de Ciências Biomédicas da Universidade de São Paulo; 2010.

Apesar de mais de 20 anos de esforço, o design de uma vacina anti-HIV eficaz ainda constitui um enorme desafio. Neste cenário, novas abordagens imunológicas devem ser consideradas. Com base em estudo pioneiro que utilizou células dendríticas derivadas de monócitos pulsadas com HIV autólogo inativado para o tratamento de indivíduos cronicamente infectados, no qual foram obtidos resultados parcialmente satisfatórios (supressão sustentada da carga viral após um ano de tratamento em apenas metade dos indivíduos vacinados), o presente projeto propôs investigar a utilização in vitro de diferentes produtos antigênicos do HIV para optimizar a apresentação antigênica por células dendríticas e a resposta protetora num maior número de indivíduos. Monócitos de pares discordantes e de indivíduos sadios não expostos ao HIV foram diferenciados in vitro em células dendríticas (DCs) e infectadas por um pool de subtipos do HIV inativados (DC-HIV), pulsadas com a proteína p55Gag do $\mathrm{HIV}_{\text {IIIB }}$ ou transduzidas pelos vetores lentivirais carregando os plasmideos pNL4-3 ${ }^{\text {HSA }}$ pol-env- (DCvNL) e pITR DC-LAMP/gag (DCvL/g). Em seguida, as DCs foram co-cultivadas com linfócitos autólogos por 7 dias. No sétimo dia, a co-cultura recebeu um reforço de DCs frescas "carregadas" com os mesmos antígenos. A resposta imunológica desenvolvida pelos linfócitos $T$ foi avaliada segundo a proliferação e ativação celular e produção de IFN $\gamma$. O perfil fenotípico e funcional das DCs também foi avaliado. Todas as DCs utilizadas no co-cultivo apresentavam-se maduras e ativadas (CD11C+HLA-DRhiCD86hiCD80hi CD83+, secretando altos níveis de MIP-1 $\alpha$ e baixos níveis de IL-10). Linfócitos estimulados por DC-HIV e DCp55 proliferaram significativamente mais e expressaram porcentagens maiores da molécula CD38 em comparação a linfócitos estimulados por DCs não pulsadas $(\mathrm{DCm})$. Entretanto, as células $\mathrm{T}$ do grupo controle apresentaram o mesmo padrão de resposta imunológica. Por outro lado, apenas os linfócitos T de pares discordantes produziram e secretaram altos níveis de IFN $\gamma$ sob estimulação por DC-HIV e DCp55. Nenhum tipo de resposta foi detectada em células estimuladas por DCvNL e DCvL/g. Este modelo vacinal mais fácil e mais barato foi capaz de estimular resposta imune celular em pessoas não infectadas pelo HIV, o que sugere um perfil de resposta mais amplo, e pode representar uma alternativa viável e promissora de vacinação terapêutica.

Palavras-chave: HIV. Célula dendrítica. Vacina terapêutica. HIV-1 inativado com AT-2. p55Gag. pNL4-3 ${ }^{\text {HSA }}$ pol-env-. DC-LAMP/Gag. 


\section{ABSTRACT}

SILVEIRA, G. G. Modulation of monocyte-derived dendritic cell antigen presentation using different HIV antigenic: potential use in therapeutic vaccine. 2010. 97 p. Master thesis (Immunology) - Instituto de Ciências Biocimédicas, Universidade de São Paulo, São Paulo, 2010.

Despite more than 20 years of effort, the design of an effective HIV-1 vaccine remains an enormous challenge. In this scenario, new immunological approaches must be considered. Dendritic cells-based vaccines have been widely used in cancer therapy showing interesting successful results. More recently, some authors described large reductions on virus load in untreated HIV-infected patients immunized with autologous DC pulsed with inactivated viruses. Although encouraging, these results showed sustained virus reduction in only half of vaccinees. Besides, isolating virus from each patient is a rather laborious and expensive process. Based on that monocyte-derived dendritic cell (Mo-DC) vaccine model we evaluated the use of alternative HIV antigen products in order to simplify the process of vaccine production, reduce costs and achieve protective immune responses on a greater number of individuals. Monocytes from HIV-serodiscordant couples and non-HIV-exposed controls were differentiated in vitro into dendritic cells, pulsed with a pool of aldrithiol-2-inactivated HIV-1 subtypes (DC-HIV), the HIV-1 ${ }_{\text {IIIB }}$ p55Gag protein (DCp55) or lentiviral vectors delivering the plasmids pNL4-3 ${ }^{\text {HSA }}$ polenv- (DCvNL) or pITR DC-LAMP/gag (DCvL/g) and then cultured with autologous lymphocytes for 7 days. At day 7 , the culture received a boost of fresh Mo-DCs pulsed with the same antigens. The $\mathrm{T}$ lymphocyte immunological response was determined by proliferation assay, IFN $\gamma$ production and cellular activation. The Mo-DC phenotype and function were also evaluated. Mo-DCs were shown to be fully matured and activated (CD11C+HLA-DRhiCD86hiCD80hiCD83+, secreting high levels of MIP- $1 \alpha$ and low amounts of $\mathrm{IL}-10$ ) in all antigen-pulsing protocols. Lymphocytes stimulated by DC-HIV and DCp55 proliferated significant more and showed higher expression of CD38 molecule than those stimulated by non-pulsed mature DCs. Nonetheless, T cells from non-exposed controls elicited the same response. On the other hand, only T lymphocytes from HIV-serodiscordant couples produced and secreted high quantities of IFN $\gamma$ upon stimulation of DC-HIV and DCp55. No immune response whatsoever was detected with DCvNL or DCvL/g stimulation. This easier and cheaper Mo-DC vaccine model elicited in vitro detectable cellular immune responses in HIV-uninfected subjects, which suggests a broader range of action and may represent a viable and promising alternative of therapeutic vaccination.

Key words: HIV. Dendritic cell. Therapeutic vaccination. AT-2-inactivated HIV-1. p55Gag. pNL4-3 ${ }^{\text {HSA }}$ pol-env-. DC-LAMP/Gag. 


\section{LISTA DE ABREVIATURAS, SÍMBOLOS e FÓRMULAS}

A - adenina, base nucleotídica

ADEE - ambulatório de dermatologia especializada

APCs - células apresentadoras de antígenos

ARVs - antirretrovirais

AT-2 - aldrithiol-2

bp - base pair, pares de base

BSA - bovine serum albumine; albumina sérica bovina

C - citosina, base nucleotídica

$\mathrm{CaCl}_{2}-$ cloreto de cálcio

$\mathrm{CD}$ - cluster of differentiation

$\mathrm{CMN}$ - células mononucleares

bDNA - branched DNA

CDNA - DNA complementar

$\mathrm{cpm}$ - contagem por minuto

CRF - circulating recombinant form

CTLs - linfócitos T citotóxicos

DC - dendritic cell; célula dendrítica

DC-LAMP - dendritic cell-lysossome-associated membrane protein; proteína associada à membrana lisossomal de células dendríticas

DMEM - Dulbecco's Modified Eagle Medium, meio de cultura

DNA - deoxyribonucleic acid; ácido desoxirribonucléico

EcoRI - Escherichia coli RI, enzima de restrição

EDTA - ethylenediaminetetraacetic acid; ácido etilenodiamino tetra-acético

EF1 $\alpha$ - elongation factor $1 \alpha$, promotor

eGFP - enhanced green fluorescence protein 
ELISA - Enzyme-Linked Immunosorbent Assay, ensaio imunoenzimático

ELISpot - Enzyme-Linked Immunosorbent spot

env - gene que codifica as proteínas de envelope do HIV

EUA - Estados Unidos da América

FACS - fluorescence-activated cell sorter

FITC - fluorescein isothiocyanate; isoticianato de fluoresceína

G - guanina, base nucleotídica

gag - gene que codifica as proteínas da matriz, capsídeo e core do HIV

GM-CSF - granulocyte macrophage colony-stimulating factor

gp $(41,120)$ - glicoproteína $(41,120)$

HAART - highly active antiretroviral therapy; terapia antirretroviral altamente ativa

hab. - habitantes

HBS - HEPES buffered saline

HC/FMUSP - Complexo Hospital das Clínicas / Faculdade de Medicina da Universidade de São Paulo

$\mathrm{HCl}$ - ácido clorídrico

HEPES - ácido etanossulfônico de 4-2-hidroxietil-1-piperazina

HIV - human immunodeficiency virus; vírus da imunodeficiência humana

HLA - human leukocyte antigen; antígeno leucocitário humano

IFN - interferon

$\mathrm{IL}$ - interleucina

IMF - intensidade média de fluorescência

IMT-USP - Instituto de Medicina Tropical da Universidade de São Paulo

INE - indivíduos não expostos (ao HIV)

$\mathrm{Kb}$ - quilobases (1000 pares de bases)

Kpnl - Klebsiella pneumoniae I, enzima de restrição 
$\mathrm{kDa}$ - quilodalton

LAMP-1 - lysossome-associated membrane protein-1; proteína associada à membrana lisossomal-1 (murina)

LB - Luria-Bertani, meio de cultura

$\log$ - logarítimo

LPS - lipopolissacarídeo

LTR - long terminal repeat

mDCs - células dendríticas maduras

MHC - major histocompatibility complex; complexo de histocompatibilidade principal

MIP-1 $\alpha$ - macrophage inflammatory protein- $1 \alpha$

MIIC - MHC class II compartment; compartimento de MHC de classe II

$\mathrm{NaCl}$ - cloreto de sódio

$\mathrm{Na}_{2} \mathrm{PO}_{4}$ - fosfato de sódio

NEB - New England Biolabs

nef-gene acessório do HIV

NIAID -National Institute of Allergy and Infection Disease

$\mathrm{NIH}$ - National Institute of Health

OMS - Organização Mundial da Saúde

PBS - phosphate buffered saline

PCR - polymerase chain reaction; reação em cadeia da polimerase

PD - par discordante

PE - phycoerythrin; ficoeritrina

PECy5 - phycoerythrin-cyanine 5; ficoeritrina-cianina 5

pGSEF - plasmídeo resultante da clonagem do inserto dc-lamp/gag no plasmídeovetor PWPXLd

PHA - phytohaemagglutinin; fitohemaglutinina

Pmel - Pseudomonas mendocina I, enzima de restrição 
pol-gene que codifica as proteínas responsáveis pela replicao do HIV

$\mathrm{RE}$ - retículo endoplasmático

rev - gene acessório do HIV

RNA - ribonucleic acid; ácido ribonucléico

RPMI - Roswell Park Memorial Institute, meio de cultura

$S A B$ - soro $A B$

SFB - soro fetal bovino

SIDA - síndrome da imunodeficiência adquirida

SIV - simian immunodeficiency virus; vírus da imunodeficiência símia

T - timina, base nucleotídica

TA - temperatura ambiente

TAP - transportador associado ao processamento antigênico

tat-gene acessório do HIV

TCR - T cell receptor, receptor de célula T

Th1 - Thelper 1; T auxiliar 1

TMB - tetramethylbenzidine; tetrametilbenzidina

TMF - transmissão materno-fetal

TNE - Tris/NaCl/EDTA

TNF - tumor necrosis factor; fator de necrose tumoral

TRIS - tris(hydroxymethyl)aminomethane; tris(hidroximetil)aminometano /HCL

TU - transduction units; unidades de transdução

$U$ - unidades

$\mathrm{UI}$ - unidade internacional

UNAIDS - Joint United Nations Program on HIV/AIDS

vif - gene acessório do HIV

vpr - gene acessório do HIV 
vpu - gene acessório do HIV

VSV-G - vesicular stomatitis virus glicoprotein; glicoproteína do vírus da estomatite vesicular 


\section{LISTA DE FIGURAS E TABELAS}

Figura 1 - Representação esquemática das estruturas do HIV -1 ......................... 22

Figura 2 - Curso natural da infecção pelo HIV ............................................... 23

Figura 3 - Mapa do plasmídeo pNL4-3 ${ }^{\mathrm{HSA}}$ pol-env-.................................... 43

Figura 4 - Mapa do plasmídeo pITR DC-LAMP/gag.................................... 43

Figura 5 - Mapas dos plasmídeos utilizados na construção do vetor lentiviral....... 44

Figura 6 - Esquema dos experimentos de obtenção das células dendríticas e co-cultivo com linfócitos autólogos............................................................. 48

Figura 7 - Esquema de análise da citometria de fluxo de células

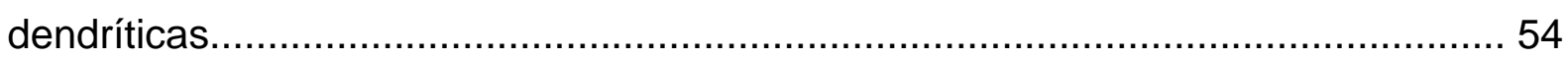

Figura 8 - Esquema de análise da citometria de fluxo de linfócitos...................... 55

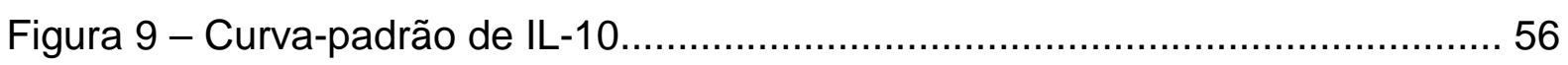

Figura 10 - Eletroforese dos plasmídeos expandidos................................... 61

Figura 11 - Confirmação do processo de clonagem do inserto dc-lamp/gag........... 62

Figura 12 - Esquema de produção dos vetores lentivirais..............................63

Figura 13 - Expressão da proteína p24 em células dendríticas imaturas............... 64

Figura 14 - Caracterização fenotípica das células dendríticas derivadas de

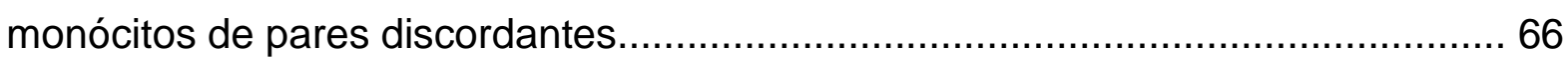

Figura 15 - Caracterização fenotípica das células dendríticas derivadas de

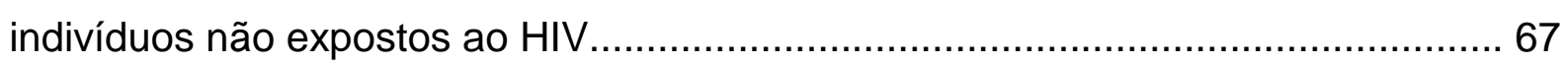

Figura 16 - Perfil fenotípico de células dendríticas de pares discordantes.............68

Figura 17 - Perfil fenotípico de células dendríticas de indivíduos não expostos ao

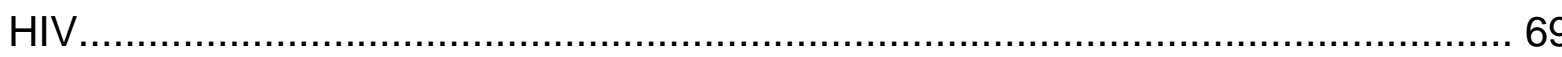

Figura 18 - Perfil de secreção de IL-10 de células dendríticas derivadas de monócitos

Figura 19 - Perfil de secreção de MIP-1 $\alpha$ de células dendríticas derivadas de monócitos 
Figura 20 - Resposta linfoproliferativa de linfócitos estimulados por células dendríticas pulsadas com antígenos do HIV.

Figura 21 - Perfil de ativação de linfócitos T estimulados por células dendríticas pulsadas com antígenos do HIV.

Figura 22 - Perfil de produção de IFN $\gamma$ de linfócitos T estimulados por células dendríticas pulsadas com antígenos do HIV 75

Figura 23 - Perfil de secreção de IFN $\gamma$ dos linfócitos estimulados por células dendríticas pulsadas com antígenos do HIV.

Figura 24 - Perfil de secreção de IL-10 dos linfócitos estimulados por células dendríticas pulsadas com antígenos do HIV

Tabela 1 - Resultados obtidos na triagem inicial dos pares discordantes pelos ensaios de proliferação celular e produção de IFN $\gamma$ em resposta a estimulação por antígenos do HIV.

Tabela 2 - Resultados obtidos na triagem inicial dos indivíduos sadios não expostos ao HIV pelos ensaios de proliferação celular e produção de IFN $\gamma$ em resposta a estimulação com antígenos do HIV 59

Tabela 3 - Composição do pool de subtipos do HIV-1 inativados por AT-2. 60 


\section{SUMÁRIO}

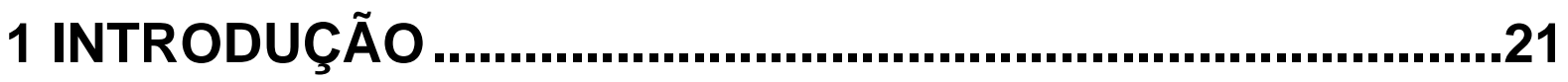

2 JUSTIFICATIVA E OBJETIVOS .......................................32

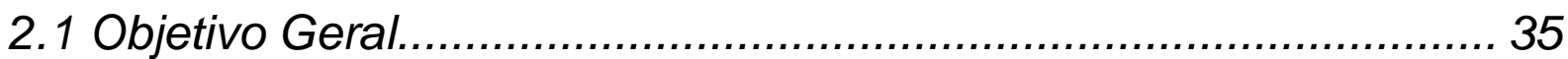

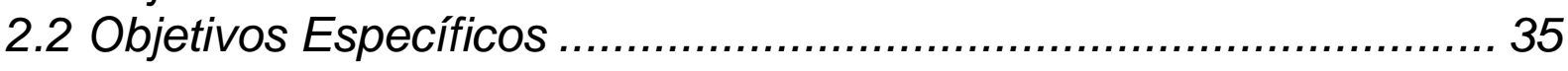

3 MATERIAIS E MÉTODOS ................................................38

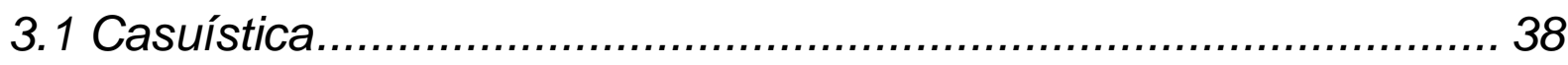

3.2 Triagem Inicial dos Indivíduos Pares Discordantes....................... 38

3.2.1 Proliferação Celular ………………………………………………....39

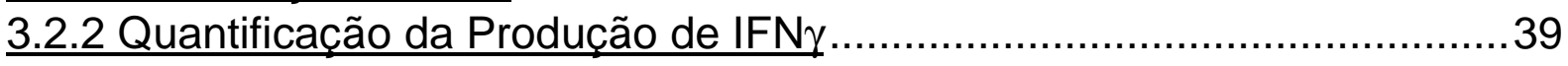

3.3 Produtos Antigênicos do HIV ...................................................... 40

3.3.1 Subtipos do HIV-1 e Confecção do Pool Viral........................................40

3.3.1.1 EXPANSÃO DOS SUBTIPOS DO HIV-1 ......................................................... 40

3.3.1.2 INATIVAÇÃ̃O E PURIFICAÇÃO DOS VÍRUS ........................................................ 41

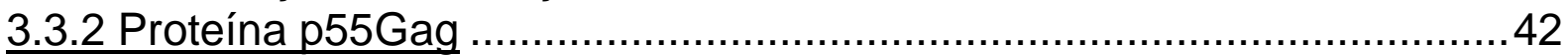

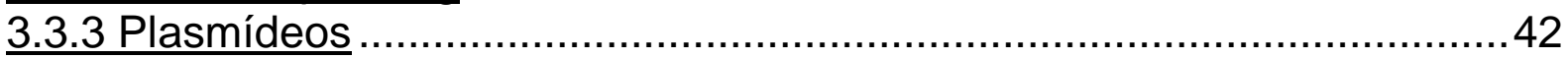

3.3.3.1 TRANSFORMAÇÃO DE BACTÉRIAS COMPETENTES E EXPANSÃO PLASMIDIAL............ 45

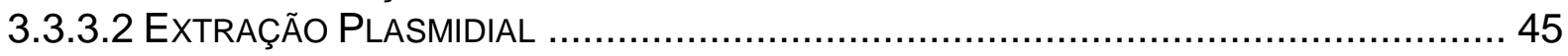

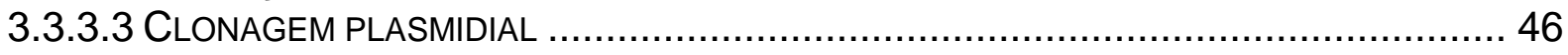

3.3.3.4 PRODUÇÃO DOS VETORES LENTIVIRAIS .................................................. 47

3.4 Esquema de Ativação in vitro de Linfócitos Estimulados por Células

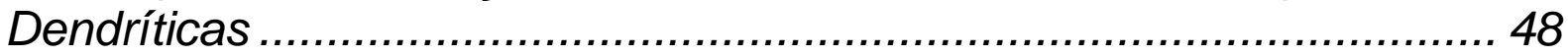

3.4.1 Geração de Células Dendríticas......................................................... 49

3.4.2 Pulso e Maturação de Células Dendríticas Imaturas ..............................49

3.4.3 Caracterização Fenotípica e Funcional de Células Dendríticas..............50

3.4.4 Co-cultivo dos Linfócitos e Células Dendríticas ……………….............50

3.4.5 Avaliação dos Linfócitos T Estimulados por Células Dendríticas............51

3.5 Ensaio de Citometria de Fluxo................................................ 51

3.5.1 Marcação de Moléculas de Superfície das Células Dendríticas .............51

3.5.2 Marcação dos Linfócitos T...............................................................52

3.5.3 Análise dos Dados de Citometria de Fluxo ………………………......53

3.6 Ensaio de ELISA para Detecção de Citocinas e Quimiocina ........... 55

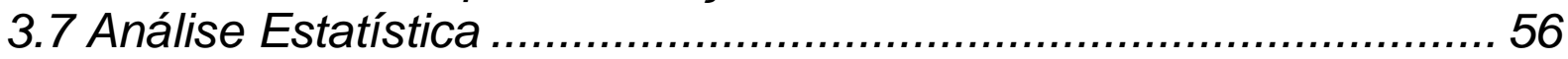

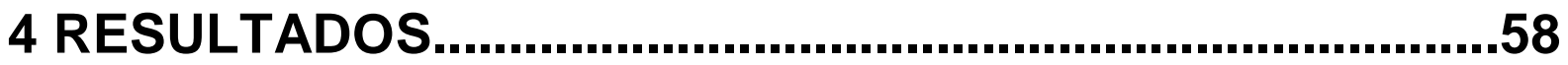

4.1 Triagem dos Indivíduos Expostos ao HIV Não Infectados .............. 58

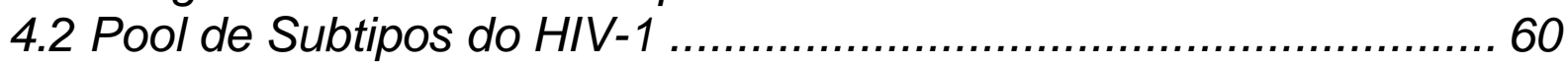

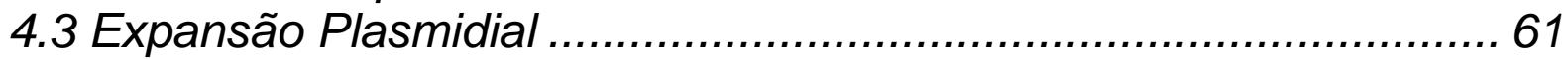

4.4 Produção dos Vetores Lentivirais ................................................ 61

4.5 Perfil Fenotípico das Células Dendríticas Diferenciadas de Monócitos 
4.6 Perfil de Secreção de Citocinas e Quimiocina das Células Dendríticas Diferenciadas de Monócitos.

4.7 Proliferação e Ativação Celular e Produção de Citocinas dos

Linfócitos T HIV-específicos Estimulados por Células Dendríticas

Autólogas

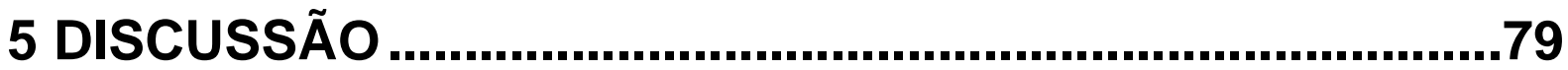

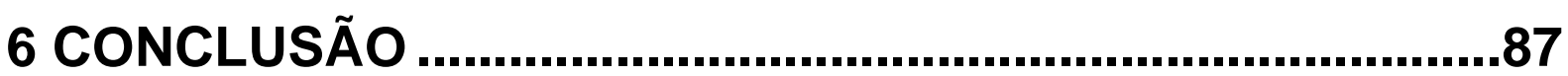

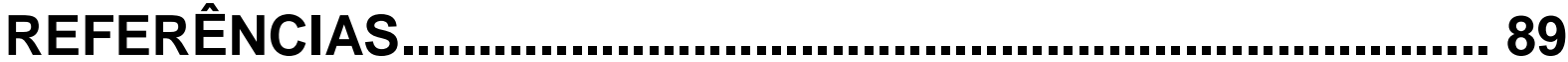




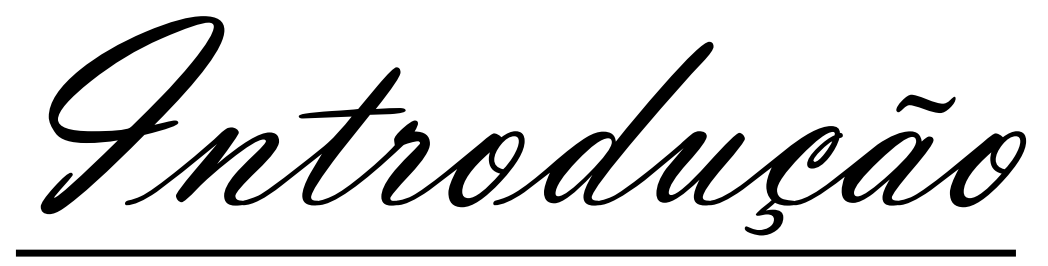




\section{INTRODUÇÃO}

O vírus da imunodeficiência humana (HIV, human immunodeficiency virus) pertence a família dos retrovírus e gênero lentivírus. Foi primeiramente descrito em 1983 por dois grupos de pesquisas independentes, um liderado por Robert Gallo nos Estados Unidos e o outro por Luc Montagnier na Franca (BARRE-SINOUSSI et al., 1983; GALLO et al., 1983). Como todos os retrovírus, o genoma do HIV é composto por RNA, especificamente duas cópias de uma fita simples positiva, o qual é convertido para DNA de dupla fita pela enzima viral transcriptase reversa após entrada na célula do hospedeiro.

Existem duas espécies de HIV: o HIV-1 e o HIV-2. O HIV-1 é a espécie mais virulenta, com maior probabilidade de transmissão e de prevalência mundial, enquanto o HIV-2 possui baixa virulência e transmissibilidade, sendo encontrado apenas nos países da África Ocidental. As duas espécies são estruturalmente muito semelhantes, porém diferem no peso molecular de suas proteínas e têm diferenças nos seus genes acessórios. O HIV-2 é mais relacionado geneticamente com o SIV encontrado nos macacos Sooty Mangabey, enquanto que o HIV-1 parece ter sido introduzido na população humana por chimpanzés. Atualmente, o HIV-1 é dividido em 3 grupos ( $\mathrm{M}, \mathrm{N}$ e $\mathrm{O})$ de acordo com diferenças encontradas no gene env. Desses, o grupo M é o mais prevalente e é subdividido em 9 subtipos (A, B, C, D, F, $\mathrm{G}, \mathrm{H}, \mathrm{J}$ e K). Ainda, mais de $40 \mathrm{CRFs}$ (circulating recombinat forms, híbridos entre subtipos, por exemplo, CRF02_AG) já foram identificadas em todo o mundo (LOS ALAMOS NATIONAL LABORATORY).

As características morfológicas gerais do HIV-1 maduro estão representadas na figura 1. Todos os lentivírus são envelopados por uma bicamada lipídica derivada da membrana da célula hospedeira. As partículas do HIV apresentam cerca de $100 \mathrm{~nm}$ de diâmetro e são recobertas por complexos glicoprotéicos formados por trímeros da glicoproteína externa gp120 e pela proteína transmembrânica gp41. A bicamada lipídica também contém diversas proteínas de membrana derivadas da célula hospedeira como moléculas de HLA (antígeno leucocitário humano), actina e ubiquitina (ARTHUR et al., 1992). Ancorada ao interior da membrana lipoprotéica viral encontra-se a matriz protéica composta por aproximadamente 2000 cópias da proteína p17. O core, localizado no centro do vírus, é composto por 2000 cópias da 
proteína p24, no qual estão inseridas duas cópias do genoma viral, estabilizadas como um complexo ribonucleoprotéico por 2000 cópias da proteína p7, juntamente com as proteínas protease p12, transcriptase reversa p66 e integrase p32, essenciais à replicação viral. Todas essas proteínas são codificadas pelos três genes estruturais do HIV: gag, pol e env. Entretanto, o RNA viral apresenta ainda seis outros genes (nef, rev, tat, vif, vpr e vpu) que codificam 7 proteínas denominadas acessórias ou regulatórias, cujas funções de controlar a habilidade de infecção do vírus e sua replicação têm sido bastante estudadas nos últimos anos (LANL, 2009).

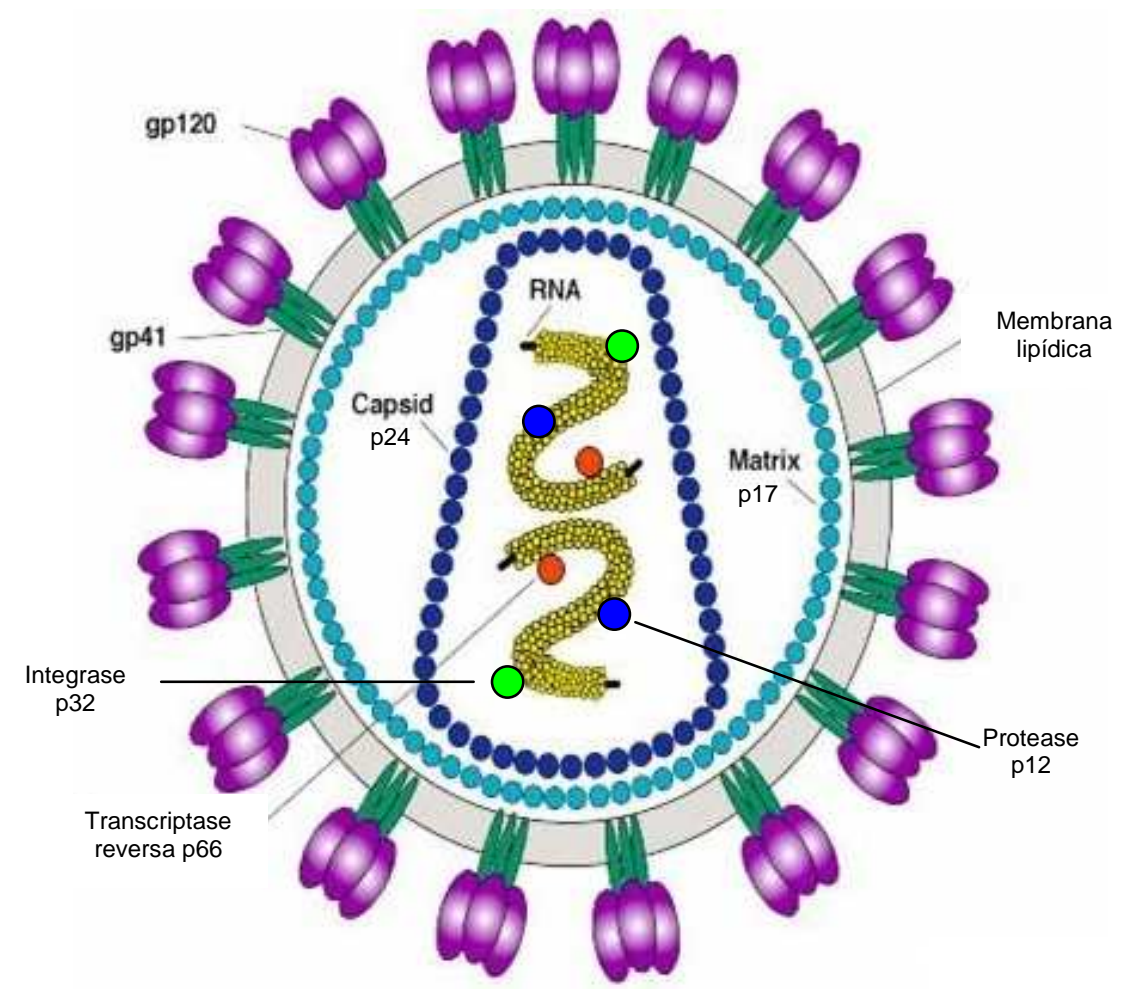

Figura 1 - Representação esquemática das estruturas do HIV-1. A figura representa graficamente a estrutura de uma partícula madura do HIV-1 com membrana de bicamada lipídica recoberta por glicoproteínas (gp120 e gp41) responsáveis pela infecção das células hospedeiras. Logo abaixo encontram-se a matriz protéica, composta por várias moléculas da proteína p17, e o capsídeo ou núcleo viral, composto por moléculas da proteína p24. Dentro do núcleo estão empacotadas as duas cópias de RNA viral, estabilizadas por milhares de moléculas da proteína $\mathrm{p} 7$, e as proteínas essências a replicação viral transcriptase reversa (p66), integrase (p32) e protease (p12).

Tipicamente, as infecções por lentivírus mostram um curso crônico de doença, um longo período de latência clínica e replicação viral persistente. A infecção pelo HIV está associada a perda progressiva de células T CD4+ e aumento da carga viral plasmática. Didaticamente, a infecção pode ser dividida em 4 estágios: período de incubação inicial (assintomático com duração de 2 a 4 
semanas); infecção aguda, período com duração média de 30 dias no qual ocorre rápida disseminação viral e perda acentuada de linfócitos T CD4+ e apresenta sintomas de infecções virais comuns como febre, linfoadenopatia, dores musculares e faringite; período de latência clínica, no qual há um equilíbrio entre a resposta imunológica do hospedeiro e a replicação viral e pode durar entre 2 semanas a mais de 20 anos; e, por fim, um estado de imunodeficiência severa, quando infecções oportunistas e/ou tumores se instalam, conhecido como síndrome da imunodeficiência adquirida (SIDA, ou, mantendo-se a sigla em inglês, aids). A figura 2 apresenta um curso médio de infecção pelo HIV em paciente não tratado.

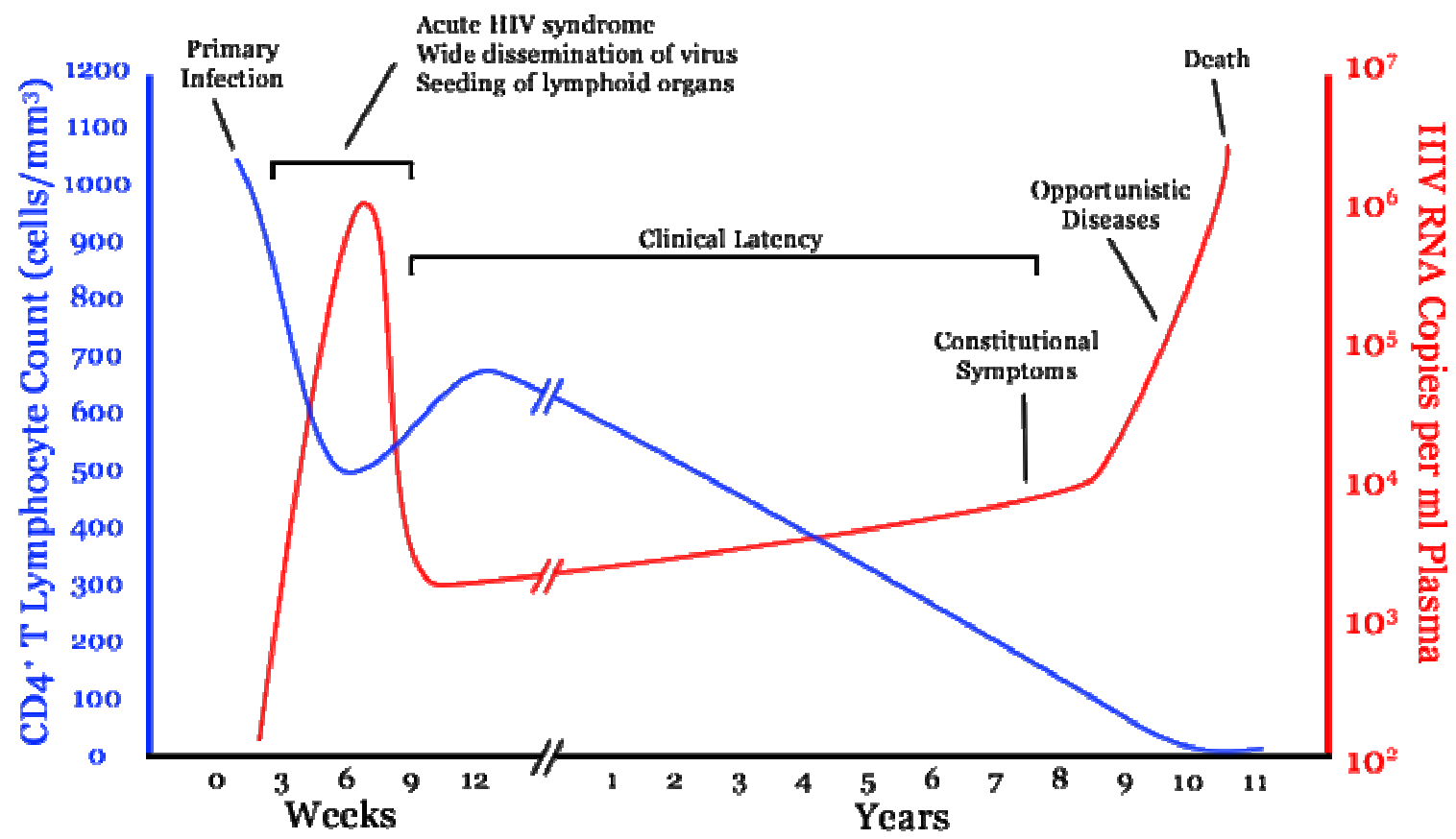

Figura 2 - Curso natural da infecção pelo HIV. O gráfico representa genericamente a relação entre cópias do HIV (carga viral) e contagem de linfócitos T CD4 durante o curso médio de uma infecção pelo HIV não tratada. Em cada paciente o curso da infecção pode variar consideravelmente.

Os primeiros relatos de aids foram descritos em 1981 como um surto de pneumonia por Pneumocystis carinii, acompanhado por casos de sarcoma de Kaposi entre os homossexuais masculinos nos Estados Unidos da America (EUA) (GOTTLIEB et al., 1981; MASUR et al., 1981). Inquéritos sorológicos e epidemiológicos posteriores mostraram que a doença se disseminou rapidamente para quase todos os países no mundo (PIOT, 1998; MASTRO e KITAYAPORN, 1998). A aids constitui um desafio sem precedentes na história moderna da saúde pública. Essa pandemia vem exigindo importantes medidas que mobilizam não só as 
autoridades sanitárias dos países envolvidos, mas também seus profissionais de saúde e instituições de pesquisa, na tentativa de minimizar seu impacto.

Desde o início da epidemia, na década de 80, até final de 2008, o Ministério da Saúde do Brasil registrou 506.499 casos de AIDS e 205.409 óbitos pela doença. Atualmente, estima-se que mais de 620.000 indivíduos estejam infectados, o que corresponde a aproximadamente $1 \%$ dos casos existentes no mundo, segundo a Organização Mundial de Saúde (OMS) (MINISTÉRIO DA SAÚDE, 2008). Entretanto, vale ressaltar, que esse problema é, sem dúvida, muito maior em outros países em desenvolvimento, como os países dos continentes africano e asiático, regiões de maior prevalência mundial. Na África Subsaariana, estima-se que 1,9 milhões de pessoas foram infectadas pelo HIV em 2007, elevando para 22 milhões o número de pessoas vivendo com HIV, isto é, 67\% do total global registrado (33 milhões). Ainda, cerca de $75 \%$ de todas as mortes relacionadas à aids em 2007 foram notificadas nessa região (UNAIDS, 2008).

A gravidade da epidemia torna-se mais aparente quando se percebe que uma boa parte das pessoas infectadas é jovem, e vem sendo acrescida, mais recentemente, pela inclusão de um grande número de crianças. De fato, segundo a OMS, estima-se que ocorreram aproximadamente 370.000 casos de infecções em crianças em 2007, resultando em mais de 2 milhões de menores infectados (UNAIDS, 2008). Dessa forma, a transmissão materno-fetal (TMF) do HIV representa um agravante na saúde pública dos países em desenvolvimento. Segundo a UNAIDS (2006), na África Subsaariana 90\% das infecções notificadas em indivíduos menores de 15 anos ocorrem por TMF. No Brasil, de 1980 até junho de 2008 , foram notificados 11.796 casos de transmissão vertical, sendo responsável por 2,9\% dos casos de infecção pelo HIV-1 (MIN. SAÚDE, 2008).

Os primeiros casos brasileiros de aids foram descritos no início dos anos 80, em grupos sociais com perfil semelhante ao dos EUA. De início com baixa incidência, a epidemia tornou-se explosiva em alguns grupos de alta vulnerabilidade, especialmente em homens que mantém relações homossexuais e em usuários de drogas injetáveis (MIN. SAÚDE, 1998). Progressivamente a infecção passou a acometer populações originalmente consideradas de baixa vulnerabilidade, e hoje a transmissão heterossexual representa um percentual significativo das novas infecções pelo HIV. Por outro lado, a transmissão por transfusão sangüínea ocorreu 
intensamente no início da epidemia, especialmente entre hemofílicos, mas atualmente encontra-se sob controle. Da mesma forma, a TMF também tem declinado progressivamente após a introdução de medidas de controle que incluem sorologia na gestação e tratamento das gestantes infectadas com drogas antirretrovirais (MIN. SAÚDE, 2005).

A incidência de aids mostrou tendência ascendente no início da epidemia brasileira, nos primeiros anos da década de 1980 até 1998, ano em que foram notificados 31.622 casos novos, traduzindo-se em uma taxa de incidência de 19,5/100.000 habitantes. Entre 1999 e 2001, a incidência decresceu ligeiramente para novamente subir a partir de 2002 (MIN. SAÚDE, 2005).

Em 1996, e principalmente 1997, o programa brasileiro de aids introduziu o tratamento com múltiplas drogas, garantido a pacientes elegíveis, atendendo à legislação federal promulgada. Essa terapia é recomendada para todos os pacientes infectados pelo HIV que sejam sintomáticos, independentemente da contagem de linfócitos T CD4+, e para aqueles assintomáticos com contagem de linfócitos $T$ CD4+ abaixo de 200 células/mm3. Quando o paciente assintomático apresenta contagem de linfócitos T CD4+ entre 200 e 350 células $/ \mathrm{mm} 3$, o início da terapia antirretroviral pode ser considerado de acordo com a evolução dos parâmetros clínicos, imunológicos, virológicos ou outras características do paciente (motivação, capacidade de adesão, co-morbidades). Dessa forma, atualmente pelo menos 165.000 indivíduos recebem terapêutica altamente ativa (HAART - highly active antiretroviral therapy) anti-HIV no Brasil. Com isso, entre 2000 e 20003, a mortalidade caiu e estabilizou-se na casa dos 10 a 11 mil óbitos anuais, com taxas em torno de 6,3 - 6,4/100.000 hab.(MIN. SAÚDE, 2005).

Entretanto, verifica-se que, mesmo com os sensíveis progressos obtidos pelo Programa de Aids do Ministério da Saúde, a doença ainda constitui um sério problema de saúde pública: a aids ainda responde sozinha por $43 \%$ de todos os óbitos por doenças infecto-parasitárias de notificação compulsória (MIN. SAÚDE, 2005). Além disso, o novo tratamento com drogas antirretrovirais (ARVs) induz alterações clínicas e laboratoriais importantes. De fato, o uso por longo prazo de ARVs tem sido associado a várias anormalidades nas concentrações séricas de lipídeos, com aumento do risco de doenças cardiovasculares, redistribuição inadequada da gordura corporal, resistência à insulina, alergias, disfunções 
gastrointestinais e reações cutâneas que, em geral, também contribuem para a não adesão ao tratamento (BORRAS-BLASCO et al., 2008; CARR, 2000; HENGEL et al., 1997; KAKUDA, 2000; MADGE et al., 1999). Essas complicações podem piorar consideravelmente a qualidade de vida do indivíduo infectado pelo HIV e sua autoestima. Cabe lembrar também que são inúmeras as interações medicamentosas, sendo algumas responsáveis pela perda da eficácia da terapia antirretroviral.

Além das alterações decorrentes da terapia ARV, o aumento de pacientes com falência terapêutica e o reconhecimento de vírus altamente patogênicos demandam medidas imediatas, exigindo reavaliação do tratamento com drogas altamente potentes. Estima-se que 10 a $20 \%$ dos pacientes que iniciam o tratamento não conseguem suprimir a viremia de forma satisfatória após alguns meses de terapia (falha virológica primária) e cerca de 20 a 50\% dos que desenvolvem boa resposta inicial apresentarão falha terapêutica após um ano de tratamento (falha virológica secundária) (MIN. SAÚDE, 2006). Portanto, o insucesso terapêutico por resistência às drogas é esperado $e$, a despeito do número crescente de medicamentos hoje fabricados, vários pacientes já encontram-se sem opções de tratamento.

A falha terapêutica de um esquema antirretroviral está associada à ocorrência de deterioração clínica e/ou piora dos parâmetros laboratoriais imunológicos e virológicos. O aparecimento de infecção oportunista é, na maior parte das vezes, um sinal de falha terapêutica. Do ponto de vista laboratorial, os principais parâmetros que sugerem falha virológica são a elevação da carga viral (maior que 0,5 log ou três vezes o valor inicial) e/ou redução significativa da contagem de linfócitos $T$ CD4+ (maior que $25 \%$ no valor absoluto ou no valor percentual). Nos casos de pacientes com extensa experiência com drogas ARVs, nos quais a supressão completa da carga viral é difícil de ser obtida, a contagem de linfócitos T CD4+ é o melhor indicador da resposta terapêutica, devendo, preferencialmente, ser monitorada após curtos intervalos de tempo para eventual modificação do esquema (MIN. SAÚDE, 2006). Desta forma, há necessidade de novos esforços para desenvolver terapias alternativas que inibam ao máximo a replicação viral.

A utilização de vacinas terapêuticas e/ou o uso de imunomoduladores têm sido apontados como possíveis intervenções para aumentar a capacidade do organismo infectado de responder contra o vírus, atendendo também a anseios 
como retardar o início da HAART, por manter os pacientes com baixa carga viral circulante (LISZIEWICS et al., 2005; MACGREGOR et al., 2005; MOSS et al., 2003). Isto implicaria numa melhor condição de vida, menor transmissão do vírus e diminuição efetiva do uso de drogas, além de reduzir o desenvolvimento precoce da resistência aos ARVs. Além disso, do ponto de vista econômico, a obtenção de uma vacina eficaz representaria redução dos gastos, não só com uso de medicamentos, mas também com assistência, uma vez que um número menor de pessoas infectadas deverá procurar hospitais e centros de saúde.

O primeiro estudo clínico de uma vacina anti-HIV foi conduzido em 1987 nos EUA e, desde então, mais de 40 vacinas candidatas foram testadas em 65 estudos de fase 1 e 2, envolvendo mais de 25.000 voluntários saudáveis distribuídos em cerca de 10 países. No entanto, apenas algumas dessas vacinas progrediram para estudos de fase 3 (GIRARD et al., 2006). Apesar dos esforços das agências de pesquisa, governos, universidades, empresas farmacêuticas e organizações internacionais, ainda não se encontram disponíveis vacinas seguras, efetivas, acessíveis e de fácil administração (IAVI, 2008). Em especial, a recente falha da vacina da Merck $^{\circledR}$ (Step Study - BUCHBINDER et al., 2008) abriu espaço à discussão de muitas questões fundamentais sobre qual seria o melhor antígeno candidato a vacina, a melhor forma de apresentá-lo ao sistema imune e que tipo de resposta imunológica deveria ser desenvolvida. Imunologistas e pesquisadores do mundo todo acreditam que são necessárias novas abordagens na produção de uma vacina anti-HIV realmente eficaz, concentrando esforços principalmente a estudos básicos da imunopatologia do HIV.

Diversos trabalhos demonstram que a ativação do sistema imunológico, particularmente da imunidade celular, desempenha um papel fundamental no controle da replicação viral durante a infecção pelo HIV (BORROW et al., 1994; FRIEDRICH et al., 2007; KOUP et al., 1994; OGG et al., 1998; van BAALEN et al., 1998, 2002; WALKER et al., 1986; YANG et al., 2003). Portanto, deve-se considerar que o estímulo da imunidade celular é um alvo importante a ser alcançado por novas modalidades vacinais. Nesse sentido, estratégias de imunização utilizando células dendríticas pulsadas com antígeno têm se mostrado uma forma racional e promissora para indução de resposta imune em pacientes com HIV (ANDRIEU e LU, 2007; LU et al., 2003, 2004). Como principal mecanismo efetor da resposta imune 
celular adaptativa, a reposta de linfócitos $T$ é dependente da apresentação antigênica por células dendríticas (DCs). Tais células constituem as principais células apresentadoras de antígeno (APCs), sendo consideradas sentinelas naturais responsáveis por iniciar a resposta imune mediada por linfócitos $T$ contra patógenos invasores, desempenhando desta forma um papel central na regulação imune (BANCHEREAU e STEINMAN, 1998; GUERMONPREZ et al., 2002; STEINMAN, 2001; STEINMAN e HEMMI, 2006). Além disso, muitos estudos já demonstraram a eficácia de protocolos de vacinação baseados em células dendríticas contra outras patologias como o câncer (SCHULER et al., 2003) e doenças infecciosas causadas por bactérias (DEMANGEL et al., 1999; MBOW et al., 1997), fungos d'OSTIANI et al., 2000), parasitas (BERBERICH et al., 2003; FLOHÉ et al., 1998) e outros vírus que não o HIV (LUDEWIG et al., 1998; SCHON et al., 2001).

As DCs induzem resposta imune através de quatro mecanismos de apresentação antigênica para os linfócitos $\mathrm{T}$ : (1) antígenos sintetizados intracelularmente, como proteínas virais, são degradados no citoplasma por proteases no proteassoma e os peptídeos gerados são transportados através do retículo endoplasmático $(\mathrm{RE})$ pelos transportadores associados ao processamento do antígeno (TAP) e associados às moléculas de classe I do complexo de histocompatibilidade principal (MHC - major histocompatibility complex) para serem transportados à superfície celular através do complexo de Golgi; (2) antígenos endocitados são degradados no endossoma por proteases quando, em paralelo, as moléculas de classe II do MHC são sintetizadas no RE, ligadas a cadeia invariável, que bloqueia a união com proteínas recém sintetizadas no lúmen, e direcionadas para os endossomas acidificados que contém os peptídeos antigênicos; nesse local a cadeia invariável é clivada e ocorre a ligação dos peptídeos às moléculas de classe II do MHC que migram para a superfície celular; (3) processamento de antígenos endógenos para apresentação via moléculas de classe II do MHC (apresentação cruzada) - antígenos são sintetizados e direcionados para os lisossomos ou endossomos onde são acoplados a moléculas de classe II do MHC; e (4) processamento de antígenos exógenos para apresentação por moléculas de classe I do MHC (apresentação cruzada) - (a) peptídeos degradados no endossoma são translocados para o citoplasma onde seguem a via comum de apresentação para antígenos citosólicos, (b) peptídeos endossômicos ligam-se a moléculas de 
classe I presentes no endossoma devido a fusão do mesmo ao RE, ou (c) os antígenos endossômicos translocados para o citoplasma são degradados por proteases e novamente direcionados para o endossoma onde se ligam a moléculas de classe I (HOWARTH e ELLIOT, 2004).

Existem pelo menos 2 principais subtipos de células dendríticas: as DCs mielóides CD11c+ (mDCs) e as DCs plasmocitóides CD123+ (pDCs). As primeiras são mais abundantes e secretam altos níveis de IL-12 durante a apresentação antigênica, enquanto as pDCs são especializadas na produção de IFN $\alpha$, desempenhando um importante papel na imunidade viral (McKENNA et al., 2005; ARDÁVIN et al., 2001; SHORTMAN e LIU, 2002; SIEGAL et al., 1999).

$\mathrm{Na}$ infecção pelo HIV, a célula dendrítica pode funcionar tanto como o alvo inicial do HIV, após exposição da mucosa ao vírus, como também pode atuar como um reservatório viral. O primeiro passo para que o HIV infecte uma DC é se ligar ao seu receptor CD4, através da proteína viral de superfície gp120, e aos correceptores CCR5 ou CXCR4. Por sua vez, a célula dendrítica também é capaz de capturar o HIV através de receptores de lectina, em especial o CD209, também denominado DC SIGN (TURVILLE et al., 2002). A infecção das DCs, com produção de proteínas virais no citosol, induz apresentação antigênica via $\mathrm{MHC}$ I e, conseqüentemente, à ativação de células T CD8+, enquanto que proteínas virais, debris de células apoptóticas infectadas e antígenos de HIV processados induzem à ativação de células T CD4+ por apresentação e reconhecimento antigênico via MHC II (RINALDO e PIAZZA, 2004). Além disso, as células dendríticas podem processar antígenos extracelulares do HIV para apresentação via MHC classe I, na ausência de replicação viral (BUSEYNE et al., 2001). Tal processo requer uma interação adequada do receptor de superfície para HIV e fusão do vírus com a membrana celular, sendo esta apresentação crucial na ativação linfocitária.

Por sua vez, células T CD4+, embora não participem da lise direta das células infectadas, desempenham importante função na modulação da resposta imune e na manutenção da resposta $\mathrm{T}$ CD8+ em muitas infecções virais persistentes (MATLOUBIAN et al., 1994), evidenciando a importância da presença dos linfócitos T CD4+ para o desenvolvimento de uma resposta imune antiviral apropriada. Segundo Hogan e Hammer (2001), existe a necessidade da presença de células T CD4+ auxiliares, juntamente com linfócitos $T$ citotóxicos (CTLs), para a redução da 
progressão da aids. Os autores também demonstram que o colapso da resposta de CTL HIV-específica, numa fase mais tardia da doença, está relacionado com a perda de atividade de células T CD4+.

Porém, durante a fase aguda, a fase de alta viremia, ocorre a redução no número de mDCs e pDCs circulantes no sangue (BARRON et al., 2003; DONAGHY et al., 2001; GRASSI et al., 1999). Ainda, a depleção de mDCs no sangue se correlaciona intimamente com o aumento da carga viral plasmática, sendo esta correlação não tão clara para as pDCs (PACANOWSKI et al., 2001). O decréscimo no número de mDCs e pDCs na circulação persiste em muitos indivíduos infectados mesmo depois do paciente iniciar o uso de HAART (CHEHIMl et al., 2002; FINKE et al., 2004; FONTAINE et al., 2009). Além disso, diversos estudos sugerem que, uma vez infectadas, as DCs exibem uma baixa expressão de CD4 e uma mudança no perfil de produção de citocinas, comparado às DCs não infectadas (BUISSON et al., 2009; CONTI et al., 2004). Assim, apesar de sua condição imunológica razoável, e mesmo adequada, no início da infecção, os indivíduos infectados não são capazes de eliminar o vírus. É possível que a impossibilidade de eliminá-lo e evitar a infecção crônica possa estar relacionada à dificuldade de reconhecer os antígenos relevantes em conseqüência da disfunção de células apresentadoras de antígenos (BARRATBOYES et al., 2002; DONAGHY et al., 2004).

O fato da ativação de uma resposta imune específica poder atuar no controle da replicação viral sugere que uma intervenção vacinal possa ser uma estratégia útil nesse processo. Ainda nesse sentido, alguns estudos mostram que células dendríticas derivadas de monócitos de indivíduos infectados podem não estar infectadas, exibem funções normais de apresentação antigênica e são capazes de desenvolver potente resposta imune HIV-específicas de células T (CHOUGNET et al., 1999; SAPP et al., 1999;). A idéia, portanto, é desenvolver uma vacina capaz de suplantar a imunodeficiência estabelecida nesses pacientes, tendo como grande desafio avaliar quais componentes do sistema imunológico devem ser preferencialmente estimulados e que estratégia utilizar para a estimulação eficiente desses componentes. 

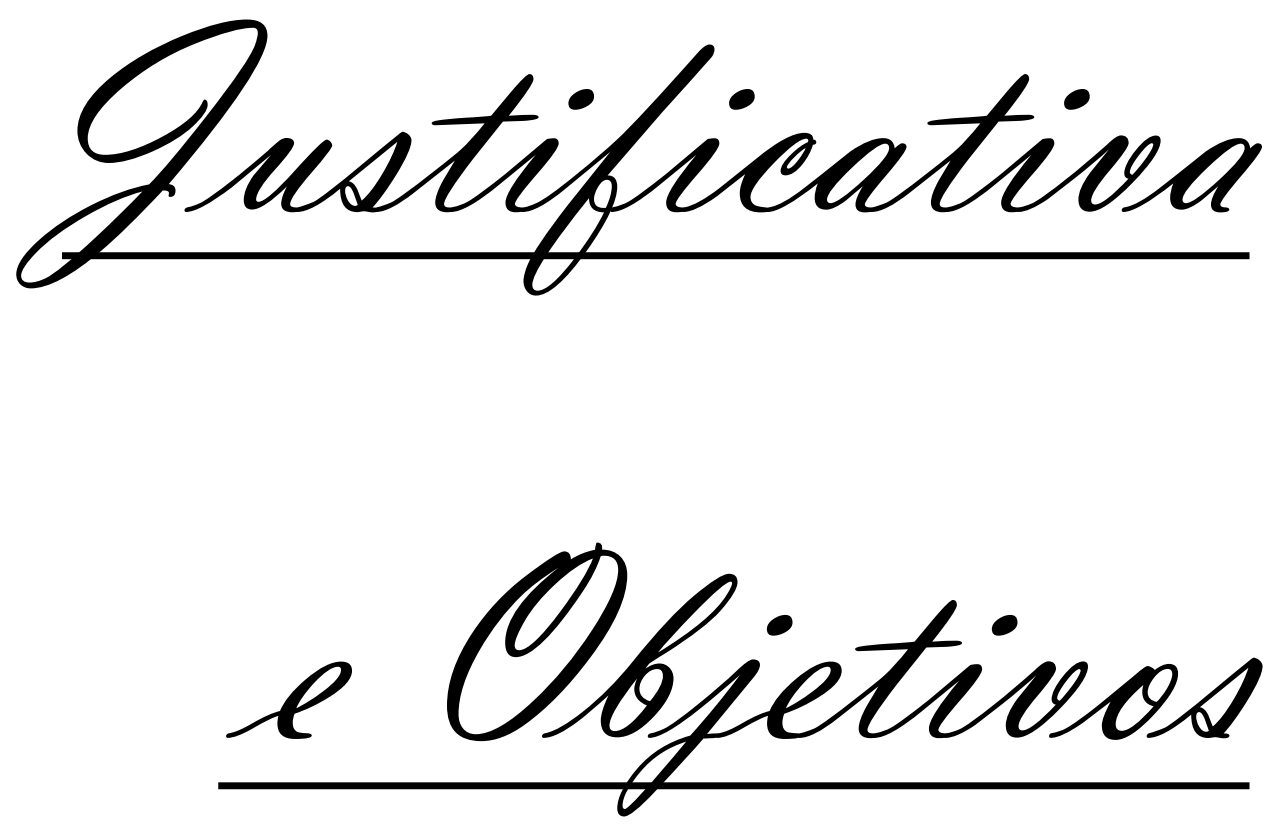


\section{JUSTIFICATIVA E OBJETIVOS}

Visando estratégias alternativas para o tratamento de pacientes infectados pelo HIV, Lu, et al. (2004) descreveram uma vacina terapêutica de células dendríticas pulsadas com vírus autólogo inativado. Nesse trabalho piloto, DCs autólogas derivadas de monócitos do sangue periférico foram utilizadas para tratar 18 pacientes cronicamente infectados, sem uso de terapêutica antirretroviral e que apresentavam carga viral estável durante os seis meses precedentes ao uso dessa vacina. Os autores relataram uma diminuição média, sustentada, da carga viral em $80 \%$ dos pacientes nos primeiros 112 dias após a vacinação e uma prolongada supressão da carga viral (por pelo menos um ano), acima de 90\% dos níveis iniciais, em oito dos 18 pacientes incluídos no estudo.

Com base nesses resultados, os pesquisadores sugeriram que a diminuição dos vírus circulantes pode adiar a introdução da medicação antirretroviral. Esses achados podem trazer impacto importante na Saúde Pública, visto que poderão fazer diminuir a necessidade de atenção médica e, sobretudo, os gastos públicos com medicamentos. Por outro lado, observa-se nesse mesmo trabalho que, embora uma parcela dos indivíduos tenha evoluído positivamente com o tratamento, mais da metade dos pacientes não foi capaz de responder adequadamente à vacina. Neste contexto, a proposta de metodologias alternativas buscando aumentar sua eficácia torna-se de grande interesse e poderia contribuir para induzir uma resposta protetora num maior número de indivíduos infectados e abrir caminho para o aperfeiçoamento deste método terapêutico.

Dessa forma, utilizando o modelo de vacina terapêutica desenvolvido por Lu, et al. (2004), este estudo teve como objetivo investigar, in vitro, a eficácia de novos protocolos de infecção/pulso/transfecção de DCs, utilizando diferentes produtos antigênicos virais, com intuito de otimizar a capacidade dessas células de apresentar antígenos do HIV a linfócitos $T$ específicos, resultando numa resposta imunológica mais eficaz. Além disso, deve-se considerar que o método original proposto para vacinação terapêutica utiliza vírus autólogo inativado para pulsar as células dendríticas, processo este que requer o isolamento do vírus do paciente, expansão in vitro, inativação e purificação. Essas etapas, bastante complexas e dispendiosas, podem se estender por cerca de 3 meses para cada paciente até 
serem concluídas, além de exigir a utilização de laboratório de nível 3 de biossegurança e recurso humano altamente qualificado. Outro ponto importante é que nem todos os pacientes são elegíveis a esse tipo de tratamento pois, conforme observado em protocolos desenvolvidos em nosso laboratório, o isolamento e expansão do HIV torna-se muito difícil nos indivíduos que apresentam carga viral abaixo de 30.000 cópias de RNA/mL.

Por essas razões, a utilização de um antígeno padrão e não individualizado para pulsar as células dendríticas pode simplificar o processo, diminuindo o intervalo entre o isolamento do vírus e a administração da vacina, reduzir o custo da vacina e permitir a inclusão também de pacientes que apresentem carga viral controlada. Para tanto, foi utilizado um pool de HIVs heterólogos inativados, representativo dos diferentes subtipos virais existentes. Esses vírus foram inativados seguindo 0 mesmo protocolo da proposta original, que não altera a estrutura viral e mantém sua conformação nativa e a capacidade da gp120 em se fundir a células, mas impede a atividade da transcriptase reversa do vírus, tornando-o não replicativo. A grande vantagem da utilização deste produto, além dos benefícios anteriormente apresentados, é que, teoricamente, ao serem utilizadas cepas diferentes do HIV para infectarem as DCs, o repertório antigênico mais diversificado deve desencadear a proliferação e ativação de um número maior de clones de linfócitos antígenos-específicos, melhorando a qualidade da resposta anti-HIV.

Visando também uma resposta anti-HIV mais específica, foi também proposto a utilização de um antígeno do HIV considerado altamente imunogênico, a proteína de 55 kilodaltons (kDa) codificada pelo gene gag (p55Gag). Diversos trabalhos demonstram que o gene viral gag do HIV-1 é uma região atrativa para construção de vacinas por ser altamente conservada entre os diversos subtipos virais e, portanto, capaz de estimular atividade celular citotóxica cruzada nos pacientes infectados (BERTOLETTI et al., 1998; LOPES et al., 2003; McKINNEY et al., 2004). Outros estudos abordando a resposta de células T CD4+ e CD8+ aos peptídeos da p55Gag consideram que a intensa resposta desenvolvida está associada à proteção (BETTS et al., 2005; PRICE et al., 2009) e ao controle da viremia durante a infecção (HUANG et al., 2008; ROLLAND et al., 2008; SERWANGA et al., 2009). Além disso, alguns pesquisadores defendem a idéia de que vacinas que induzem resposta contra proteínas expressas precocemente (antes do ciclo replicativo do HIV 
terminar), como a Gag, que é o primeiro antígeno a ser exposto na membrana celular, são ideais pois os linfócitos T CD8+ reconheceriam as células infectadas antes de novos vírus sem liberados (SACHA et al., 2007).

Dentre os métodos de "entrega de antígenos" testados nas vacinas baseadas em DCs, a transfecção com DNA plasmidial representa uma atrativa fonte de múltiplos epítopos capazes de estimular a resposta imunológica celular e humoral (ESTCOURT et al., 2004; RAJCÁNI et al., 2005). O aspecto racional deste tipo de estratégia encontra-se no fato de que o plasmídeo pode ser rapidamente desenhado em laboratório e indefinidamente multiplicado em sistemas bacterianos, gerando uma grande quantidade de cópias e possibilitando a redução no tempo e no custo de produção da vacina terapêutica anti-HIV (BAROUCH, 2006; KASLOW, 2004; SHEETS, et al., 2006). Assim, no presente estudo utilizou-se o plasmídeo pNL4$3^{\mathrm{HSA}}$ pol-env-, que corresponde ao material genético completo do HIV (inclusive gag), com mutações nos genes pol e env.

No entanto, sabe-se que para desenvolvimento de uma boa resposta imune humoral e T CD8+ citotóxica, linfócitos T CD4+ devem ser ativados via apresentação de epítopos por HLA de classe II e ainda que o aparecimento de memória imunológica está intimamente ligado à esse contexto de apresentação antigênica (DE ARRUDA et al., 2004). Todavia, como essa via de apresentação é convencionalmente mediada por endocitose ou fagocitose de antígenos exógenos, é possível que antígenos endógenos sintetizados por plasmídeos não participem eficientemente dessa via e sejam limitados na função de ativar os linfócitos T CD4+. Dessa forma, um segundo plasmídeo denominado pITR DC-LAMP/gag foi testado. Esse plasmídeo possui um gene quimérico que codifica a proteína p55Gag do HIV-1 HXB2 entre a porção citoplasmática e luminal da proteína associada à membrana lisossomal de células dendríticas (DC-LAMP - dendritic cell-lysossome-associated membrane protein). A DC-LAMP é uma proteína relacionada aos compartimentos lisossomais/endossomais MIIC da célula dendrítica, onde se co-localizam as moléculas de classe II do MHC. Por isso, seu papel é de direcionar a proteína viral para os compartimentos especializados fazendo com que ela seja apresentada pelo HLA de classe II (ARRUDA et al., 2006). Utilizando o similar murino da DC-LAMP, a LAMP-1, Marques, et al. (2003) demonstraram que a quimera constituída pela LAMP-1 e a p55Gag é fortemente expressa quando transfectada em células 
humanas e apresenta um direcionamento para o compartimento MIIC. A imunização de camundongos adultos com essa proteína demonstrou ser mais eficiente na indução da resposta humoral e celular específica quando comparada ao DNA que codifica apenas a p55Gag, sendo capaz de aumentar em 10 vezes a resposta das células T CD4+, cerca de 5 vezes das células T CD8+ e elevar até 100 vezes o título de anticorpos anti-Gag.

Assim, através da avaliação do uso dos diferentes produtos virais, buscou-se selecionar aqueles potencialmente capazes de aumentar a resposta imunológica linfocitária estimulada por células dendríticas, no sentido de indicar metodologias alternativas para o preparo da vacina terapêutica.

\subsection{Objetivo Geral}

Analisar metodologias capazes de infectar/transfectar células dendríticas derivadas de monócitos, no sentido de maximizar o potencial de apresentação de antígenos do HIV, e avaliar a resposta imunológica desenvolvida por linfócitos T estimulados por essas células dendríticas.

\subsection{Objetivos Específicos}

a) Testar metodologias de infecção/transfecção de células dendríticas derivadas de monócitos, utilizando diferentes produtos antigênicos do HIV:

- Protocolo 1: Infecção das células dendríticas imaturas com pool de subtipos do HIV-1 inativados por aldrithiol-2 (AT-2).

- Protocolo 2: Pulso de células dendríticas imaturas com a proteína inteira p55Gag do vírus HIV ${ }_{\text {IIIB. }}$.

- Protocolo 3: Transdução de células dendríticas imaturas com o vetor lentiviral PAX2, pseudotipado com VSV-G, carregando o plasmídeo pNL4-3 ${ }^{\text {HSA }}$ pol-env-.

- Protocolo 4: Transdução de células dendríticas imaturas com o vetor lentiviral PAX2, pseudotipado com VSV-G, carregando o plasmídeo pITR DC-LAMP/gag.

b) Investigar as características fenotípicas e funcionais das células dendríticas infectadas/pulsadas/transduzidas com diferentes produtos virais, no que 
diz respeito à expressão de moléculas marcadoras de linhagem específica (CD11C, CD14), de apresentação antigênica, co-estimulação e ativação (HLA-DR, CD86, CD80, CD83) e a produção de citocinas (IL-12p70 e IL-10) e quimiocina (MIP-1 $\alpha$ ).

c) Avaliar o potencial de apresentação de antígenos do HIV por células dendríticas através de co-cultivo com linfócitos autólogos e determinar a resposta imune desenvolvida pelos mesmos através da quantificação de proliferação e ativação celular e produção das citocinas IFN $\gamma$ e IL-10. 


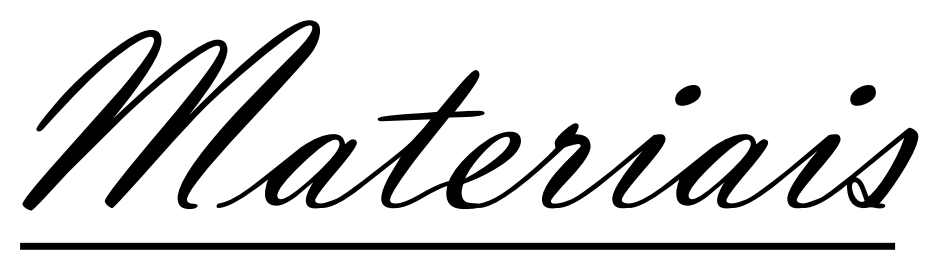

e Métodos 


\section{MATERIAIS E MÉTODOS}

\subsection{Casuística}

Foram incluídos 20 indivíduos sadios altamente expostos ao HIV, porém não infectados, selecionados no Ambulatório ADEE - 3002 do Departamento de Dermatologia do Hospital das Clínicas da Faculdade de Medicina da Universidade de São Paulo (HC/FMUSP) e no Instituto de Infectologia Emílio Ribas. Neste estudo, esse grupo foi formado unicamente por parceiros e/ou cônjuges de pacientes infectados pelo HIV, comumente denominados de "pares discordantes" ou "sorodivergentes". Após triagem inicial para confirmação da real exposição ao vírus e do desenvolvimento de memória imunológica anti-HIV, participaram efetivamente do estudo 7 desses indivíduos.

Quatro pessoas sadias não expostas ao HIV foram selecionadas no Laboratório de Investigação em Dermatologia e Imunodeficiências - LIM56 do Departamento de Dermatologia, FMUSP e incluídas no estudo como grupo controle.

Todos declararam participação voluntária após aplicação e assinatura do Termo de Consentimento Livre e Esclarecido, de acordo com a resolução n 196/96 do Conselho Nacional de Saúde sobre pesquisas envolvendo seres humanos.

\subsection{Triagem Inicial dos Indivíduos Pares Discordantes}

Para confirmação da prévia exposição ao vírus e do desenvolvimento de memória imunológica anti-HIV, os indivíduos pares discordantes e o grupo controle foram submetidos aos ensaios de proliferação celular e produção da citocina IFN $\gamma$ em resposta a estimulação com antígenos virais.

Foram considerados verdadeiramente expostos aqueles indivíduos que atenderam a pelo menos uma destas duas condições em resposta à pelo menos um dos antígenos utilizados:

a) Para o ensaio de proliferação celular, contagem por minuto $(\mathrm{cpm})>$ 1000 e índice de estimulação (I.E, proliferação de células estimuladas $\div$ proliferação basal) $>2$; 
b) Para ensaio de produção de IFN $\gamma$, quantidade produzida por células estimuladas - produção basal $>100 \mathrm{pg} / \mathrm{mL}$.

\subsubsection{Proliferação Celular}

Células mononucleares (CMN) foram isoladas por centrifugação com gradiente de Ficoll-Paque (GE HealthCare, densidade $1077 \mathrm{~g} / \mathrm{mL}$ ) de cerca de $10 \mathrm{~mL}$ de sangue periférico heparinizado e colocadas em placas de 96 poços de fundo chato (Costar, Cambridge, MA, EUA) na concentração de $2,5 \times 10^{5}$ células/poço diluídas em meio RPMI-1640 (GIBCO-BRL, Gaithersburg, MD, EUA) suplementado com $20 \mathrm{mM}$ HEPES (GIBCO-BRL), $2 \mathrm{mM}$ de glutamina (GIBCO-BRL), $0.1 \mathrm{mM}$ de piruvato de sódio (GIBCO-BRL) [meio completo] e 10\% de soro AB humano inativado (SAB; Sigma-Aldrich, St. Louis, MO, EUA). As CMN foram cultivadas em estufa (Thermo Fisher Scientific, Waltham, MA, EUA) a $37^{\circ} \mathrm{C} \mathrm{e}$ atmosfera de $5 \% \mathrm{CO}_{2}$ por 6 dias com dois diferentes antígenos do HIV: proteína p55Gag $(5 \mu \mathrm{g} / \mathrm{mL}, \quad \mathrm{NIH}$ AIDS Reagents Program, disponível em http://aidsreagent.org) ou pool de subtipos de HIV inativados com AT-2 ( $10^{9}$ partículas virais $/ \mathrm{mL}$ ). Células incubadas somente com o meio completo foram utilizadas para calcular a proliferação basal enquanto que o cultivo das mesmas por 3 dias com o mitógeno fitohemaglutinina (PHA, 2,5 $\mu \mathrm{g} / \mathrm{mL}$; Sigma-Aldrich) foi adotado como controle positivo interno do ensaio. Dezoito horas antes do término do cultivo, as culturas foram pulsadas com timidina tritiada $\left({ }^{3} \mathrm{H}, 1 \mathrm{mC} / \mathrm{mL}\right.$, GE Healthcare Bioscience, Pittsburgh, PA, EUA). As células foram então aspiradas e transferidas para uma membrana de nitrocelulose com auxílio de um coletor de células (Flow Laboratories, Rockville, MD, EUA) e a radioatividade incorporada foi medida por um contador de radiação $\beta$ (Betaplate 1205, Wallac, PerkinElmer, Waltham MA, USA).

\subsubsection{Quantificação da Produção de IFN}

Imediatamente antes da adição de timidina tritiada (aproximadamente 120 horas), $35 \mu \mathrm{L}$ de sobrenadante/poço foram coletados das células em cultura com antígenos virais, mitógeno e condição basal. Essas alíquotas foram centrifugadas rapidamente para eliminação de debris celulares e conservadas a $-80^{\circ} \mathrm{C}$ até a dosagem do IFN $\gamma$ secretado, realizada pela técnica de ELISA conforme metodologia do fabricante (DuoSet, R\&D Systems, Minneapolis, MN, EUA). 


\subsection{Produtos Antigênicos do HIV}

No intuito de avaliar alterações dos padrões de apresentação antígenos por células dendríticas e/ou de ativação dos linfócitos T foram utilizados quatro produtos antigênicos distintos do HIV-1:

- Pool de diversos subtipos do HIV-1, inativados por AT-2.

- Proteína p55Gag do HIV

- Plasmídeo pNL4-3 ${ }^{\mathrm{HSA}}$ pol-env-, que apresenta a maioria dos genes do HIV com exceção do gene pol, env e nef

- Plasmídeo pITR DC-LAMP/gag, que codifica a proteína quimérica [DC-LAMP / p55Gag / DC-LAMP ${ }^{\mathrm{CT}}$ ].

\subsubsection{Subtipos do HIV-1 e Confecção do Pool Viral}

Para obtenção do pool de HIV-1, amostras de vários subtipos virais foram adquiridas pelo NIH AIDS Reagents Program. Os subtipos recebidos foram: HIV-1 96USSN20, grupo M, subtipo A (GenBank AF096341); HIV-1 1165 MB, grupo M, subtipo C; HIV-1 $1_{\mathrm{BCB} 93}$, grupo M, subtipo D (GenBank Z95437); e HIV-1 ${ }_{\mathrm{G} 3}$, grupo M, subtipo G (GenBank U88825). Foram também incluídas amostras do grupo $M$, subtipos B e F, provenientes de pacientes brasileiros, gentilmente cedidas pela Dr. Telma Miyuki Oshiro (Laboratório de Investigação em Dermatologia e Imunodeficiências - LIM56, FMUSP).

Após expansão e inativação, os subtipos virais foram misturados numa mesma solução na mesma proporção, aliquotados a $10^{9}$ partículas virais/tubo e armazenados a $-80^{\circ} \mathrm{C}$ para posterior utilização na infecção das células dendríticas imaturas.

\subsubsection{EXPANSÃO DOS SUBTIPOS DO HIV-1}

A expansão dos vírus obtidos do $\mathrm{NIH}$ foi realizada segundo protocolo obtido da ACTG Laboratory Technologist Committee (disponível em https://www.actgnetwork.org), com algumas modificações, na sala de nível 3 de biossegurança do Laboratório de Virologia do Instituto de Medicina Tropical (IMT-USP), cujo acesso foi gentilmente cedido pelo Prof. Dr. Cláudio Panutti. 
As ampolas contendo os subtipos virais foram descongeladas e adicionadas a CMN de doadores sadios previamente ativadas com PHA por 48 horas e cultivadas em meio de cultura RPMI-1640 completo suplementado com 10\% de soro fetal bovino (SFB, GIBCO-BRL) e $20 \mathrm{UI} / \mathrm{mL}$ de interleucina (IL)-2 (PeproTech, Rock Hill, $\mathrm{NJ}$, EUA) em estufa a $37^{\circ} \mathrm{C}$ e atmosfera de $5 \%$ de $\mathrm{CO}_{2}$. O meio de cultura foi trocado a cada 3 dias e semanalmente as culturas foram realimentadas com $10^{7} \mathrm{CMN}$ de doadores sadios previamente ativadas com PHA.

A cada troca de meio de cultura, o sobrenadante contendo as partículas virais foi armazenado a $-20^{\circ} \mathrm{C}$ para posterior inativação, sendo uma alíquota separada para monitoramento da proteína p24 pelo método de ELISA (Vironostika ${ }^{\circledR} \mathrm{HIV}-1$ Antigen, bioMérieux AS, Marcy l'Etoile, França). Após acúmulo de cerca de $250 \mathrm{~mL}$ de sobrenadante comprovadamente positivo para a proteína p24, as culturas foram finalizadas. Por medida de segurança, as CMN do último dia de cultura foram armazenadas em nitrogênio líquido e o sobrenadante congelado a $-80^{\circ} \mathrm{C}$, caso houvesse necessidade de nova expansão de determinado subtipo viral.

\subsubsection{INATIVAÇÃO E PURIFICAÇÃO DOS VÍRUS}

Para a inativação dos vírus obtidos por expansão em CMN de doador sadio foi utilizado o protocolo descrito por Rossio, et al.(1998), com algumas modificações.

O volume total dos sobrenadantes obtidos nas culturas de expansão viral foi incubado com $250 \mu \mathrm{M}$ de AT-2 (Sigma-Aldrich) por 1 hora a $37^{\circ} \mathrm{C}$ e por mais 18 horas a $4^{\circ} \mathrm{C}$, sempre sob agitação constante. Então, a solução foi centrifugada a $3000 \mathrm{~g}$ por 20 minutos para remoção de debris celulares e concentrada em dispositivo de ultra filtração Amicon (Millipore, Billerica, MA, EUA) com membrana de 100 kDa por centrifugação a $2880 \mathrm{~g}$ durante 20 minutos. O volume total concentrado foi lavado 2 vezes em PBS estéril para remoção do AT-2.

A purificação dos vírus foi realizada por centrifugação em ultracentrífuga L80 Beckman (Beckman Coulter, Brea, CA, EUA), utilizando o rotor de ângulo móvel SW41 Ti. Para tanto, o material foi acondicionado sobre solução de sacarose $20 \%$ em TNE (20 mM de Tris/HCl, 20 mM de $\mathrm{NaCl}$ e 2,5 mM de EDTA), na proporção de $1 / 3$ de sacarose e 2/3 de sobrenadante concentrado e, em seguida, centrifugado a $4^{\circ} \mathrm{C}$ por 1 hora a $100.000 \mathrm{~g}$. Após este período, todo o sobrenadante acima da sacarose foi removido e o pellet ressuspendido em TNE. Procedeu-se nova 
centrifugação por mais 1 hora a 100.000 g. O pellet resultante, composto apenas pelos vírus, foi ressuspendido em meio de cultura AIM-V (GIBCO-BRL), aliquotado e armazenado a $-80^{\circ} \mathrm{C}$.

Para quantificação do número de partículas virais, nossas amostras foram incluídas na rotina de carga viral realizada em nosso laboratório pelo biólogo José Eduardo Rodrigues Martins, utilizando a metodologia de branched DNA em aparelho System 340 bDNA Analyzer (Bayer, Leverkusen, Alemanha).

O processo de inativação viral foi confirmado monitorando-se os níveis da proteína p24 em sobrenadante de cultura celular de CMN de doador sadio cultivadas com uma alíquota das partículas virais inativadas durante 4 semanas.

\subsubsection{Proteína p55Gag}

A proteína p55Gag corresponde a proteína inteira de aproximadamente $55 \mathrm{kDa}$ do HIV-1 $1_{\text {IIIB }}$ obtida pelo NIH AIDS Reagents Program, disponível em http://aidsreagent.org.

\subsubsection{Plasmídeos}

Para transdução de células dendríticas foram utilizados os plasmídeos pNL4-3 ${ }^{\mathrm{HSA}}$ pol-env- e pITR DC-LAMP/gag. Para construção dos vetores lentivirais pseudotipados foram utilizados os plasmídeos pMD2.G, psPAX2 e pWPXLd.

O plasmídeo pNL4-3 ${ }^{\mathrm{HSA}}$ pol-env-, gentilmente cedido pelos Dr. Michael J. Lenardo e Dra. Keiko Sakai (Laboratory of Immunology, NAID, NIH), expressa o genoma completo do HIV-1, porém apresenta mutações nas seqüências pol e env, que eliminam a expressão de suas respectivas proteínas, mas não afeta a expressão da Gag ou das proteínas acessórias: na pol, foi introduzido um stop códon na posição 2 da seqüência de aminoácidos (F2 stop - TTA para TAA); e na env foi introduzido um frameshift na posição 62 de aminoácidos (D62 frameshift GCA TAT GAT para CGA TAT ATG ATA). Além disso, a seqüência nef foi substituída pela seqüência de um gene repórter que codifica a proteína murina HSA. 


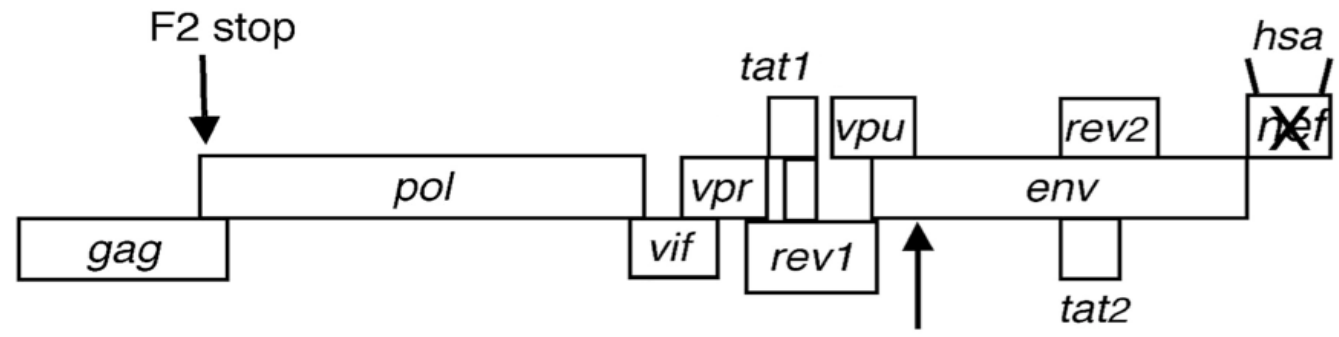

D62 frameshift

Figura 3 - Mapa do plasmídeo pNL4-3 ${ }^{\mathrm{HSA}}$ pol-env-. Representação esquemática do plasmídeo pNL4-3 ${ }^{\text {HSA }}$ pol-env- apresentando os genes codificados e as mutações inseridas.

O plasmídeo pITR DC-LAMP/gag, gentilmente cedido pelo Dr. Ernesto Marques (Department of Pharmacology and Molecular Sciences, The Johns Hopkins School of Medicine) foi construído de cDNA obtido a partir da biblioteca de tecido pulmonar humano (GenBank acesso AB013924) e expressa uma seqüência que codifica a proteína quimérica da proteína p55Gag do HIV-1 HXB2 e a proteína DC-LAMP, a DC-LAMP/Gag. Essa seqüência foi produzida pela inserção da seqüência da p55Gag entre as seqüências que codificam o domínio luminal $\left(D C-L A M P^{L}\right)$ e a porção citoplasmática e transmembrânica (DC-LAMP ${ }^{C T}$ ) da DC-LAMP (ARRUDA et al., 2006).
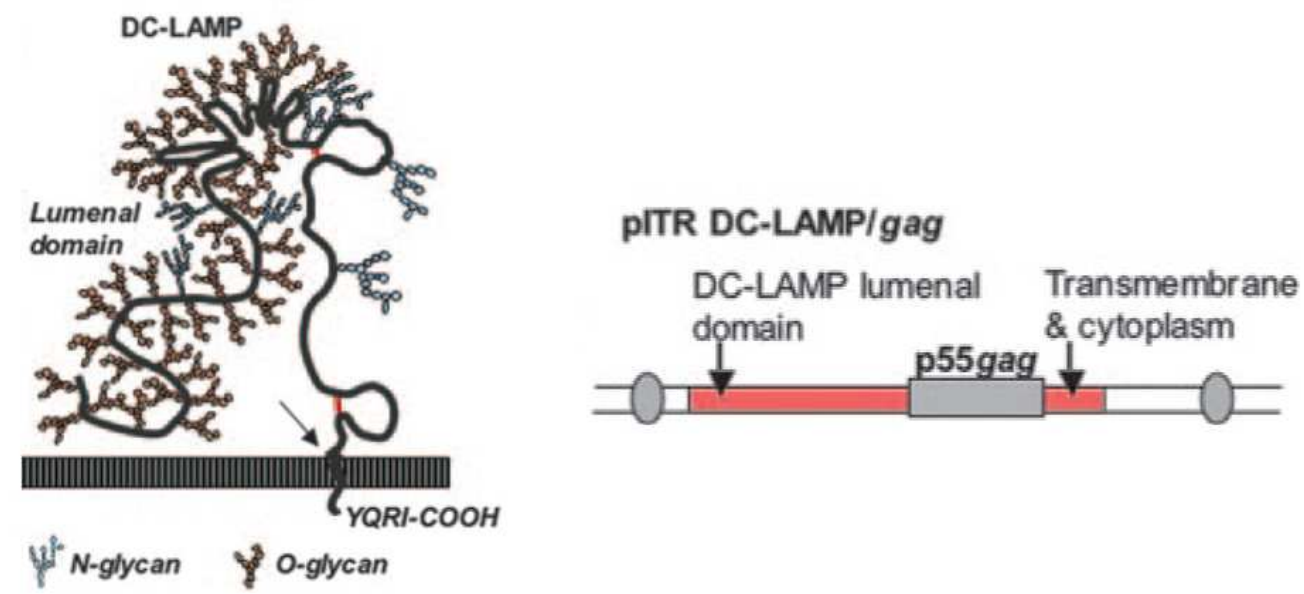

Figura 4 - Mapa do plasmídeo pITR DC-LAMP/gag. Respresentação esquemática da proteína DCLAMP ancorada a membrana plasmática (esquerda) e do plasmídeo pITR DCLAMP/gag demonstrando a seqüência do gene gag inserido entre as porções do gene dc-lamp. A seta da figura da esquerda representa o local onde a proteína p55Gag será expressa na proteína quimérica resultante.

O pMD2.G é o plasmídeo que codifica o envelope do vetor lentiviral expressando a glicoproteína G do vírus da estomatite vesicular (VSV-G). Esse vírus 
pertence a família Rhabdoviridae e é comumente utilizado para pseudotipagem de vetores virais devido ao seu amplo tropismo celular. O psPAX2 é um vetor empacotador de $2^{a}$ geração que codifica uma variante do capsídeo e da transcriptase reversa do HIV além de outras proteínas, necessárias para o empacotamento do material genético. Finalmente, o pWPXLd é um plasmídeo-vetor de clonagem que expressa as terminações LTR e a seqüência $\psi$ do HIV, essenciais para direcionamento do material genético a ser empacotado, além de outros como o promotor EF-1 $\alpha$ e o gene-repórter EGFP (enhanced green fluorescent protein). Os três plasmídeos foram adquiridos pelo repositório de plasmídeos Addgene (disponível em http://addgene.org).
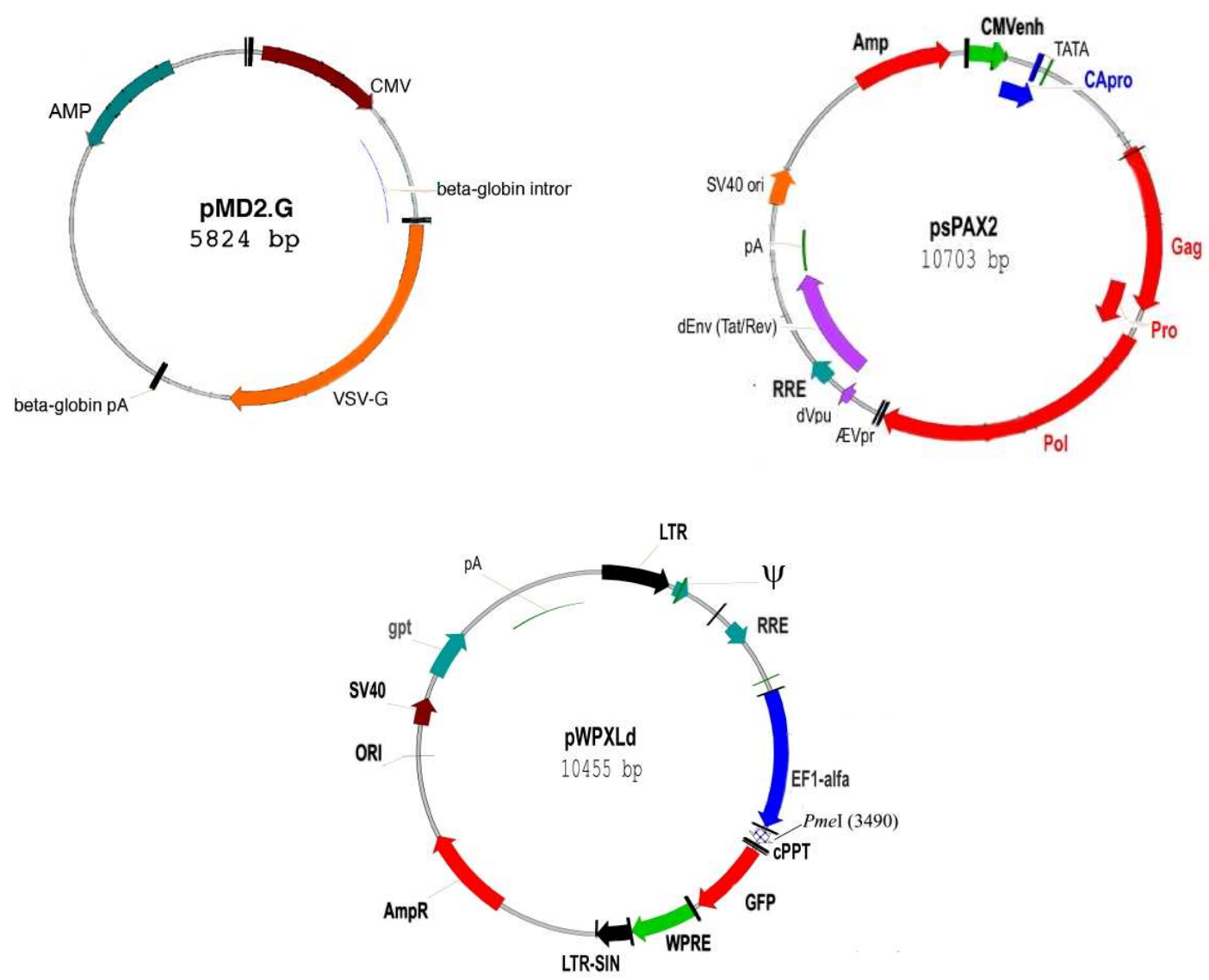

Figura 5 - Mapas dos plasmídeos utilizados na construção do vetor lentiviral. Representação esquemática dos plasmídeos pMD2.G, psPAX2 e pWPXLd. O pMD2.G (superior à esquerda) codifica a proteína VSV-G do envelope do vetor lentiviral (pseudotipagem). O psPAX2 (superior à direita) codifica o capsídeo do vetor viral, bem como proteínas responsáveis pelo empacotamento do gene específico de interesse. O pWPXLd (inferior) é um plasmídeo-vetor que contém as seqüências LTR e y necessárias ao direcionamento do gene a ser empacotado; foi utilizado para clonagem do gene dc-lamp/gag. 


\subsubsection{TRANSFORMAÇÃO DE BACTÉRIAS COMPETENTES E EXPANSÃO PLASMIDIAL}

Após recebimento dos plasmídeos que foram utilizados neste estudo, foi necessário que os mesmos fossem expandidos até atingir concentrações adequadas para realização dos diversos experimentos. Tal etapa foi realizada em sistema bacteriano de Escherichia coli, conforme o seguinte protocolo: $100 \mu \mathrm{L}$ de bactérias $\mathrm{DH} 5 \alpha$ quimiocompetentes, gentilmente cedidas pela Dra. Maria Notomi Sato (Laboratório de Investigação em Dermatologia e Imunodeficiências - LIM-56, FMUSP) foram adicionadas em tubo contendo $1 \mu \mathrm{L}$ de DNA plasmidial a ser transformado. As bactérias foram então incubadas no gelo por 5 minutos e transferidas para termobloco aquecido a $42^{\circ} \mathrm{C}$ durante 90 segundos. Após adição de $1 \mathrm{~mL}$ de meio LB (20 g/L, USB Corporation, Cleveland, $\mathrm{OH}$, EUA) seguiu-se uma hora de incubação a $37^{\circ} \mathrm{C}$ sob constante agitação. Em seguida, essa solução foi centrifugada a $2300 \mathrm{~g}$ durante 1 minuto e o sobrenadante descartado. O pellet de bactérias resultante foi homogeneizado e todo o volume plaqueado em ágar LB (32 g/L, USB Corporation) suplementado com $100 \mathrm{mg} / \mathrm{mL}$ de ampicilina (Invitrogen $^{\mathrm{TM}}$, Camarillo, CA, EUA). Após 24 horas de incubação a 37ํㅡ, uma colônia foi extraída com auxílio de microponteira estéril e repicada em tubo plástico cônico contendo $5 \mathrm{~mL}$ de meio LB suplementado com ampicilina (LB-Amp, $100 \mathrm{mg} / \mathrm{mL}$ ). Após nova incubação a 37º C e agitação constante durante 18 horas, $500 \mu \mathrm{l}$ do meio foi transferido para tubo contendo $25 \mathrm{~mL}$ de meio LB-Amp e novamente incubado às mesmas condições. No dia seguinte, as bactérias foram centrifugadas a $5000 \mathrm{~g}$, seguindo-se à etapa de extração do DNA.

\subsubsection{EXTRAÇÃO PLASMIDIAL}

Para confirmação da expansão plasmidial e checagem do plasmídeo expandido, primeiramente foi realizada uma extração menor utilizando-se o kit comercial QIAprep ${ }^{\circledR}$ Spin Miniprep Kit (QIAGEN, Valencia, CA, EUA). Confirmada a expansão do plasmídeo correto, a extração maior e purificação do DNA plasmidial foi realizada utilizando-se o kit Endofree ${ }^{\circledR}$ Plasmid Maxi Kit (QIAGEN), conforme protocolo recomendado pelo fabricante. Resumidamente, esse kit é composto por uma série de soluções enzimáticas (RNAse, proteases e DNAse de DNA cromossômico), colunas de sílica para separação do DNA plasmidial e filtros que garantem que o material purificado seja livre de endotoxinas. 
A concentração plasmidial obtida foi quantificada pelo espectrofotômetro ND-1000 (NanoDrop ${ }^{\circledR}$, Thermo Scientific) e os plasmídeos armazenados a $-80^{\circ} \mathrm{C}$ para posterior utilização nos ensaios de construção de vetores lentivirais.

\subsubsection{CLONAGEM PLASMIDIAL}

Como o plasmídeo pNL4-3 ${ }^{\mathrm{HSA}}$ pol-env- expressa o genoma quase completo do HIV, inclusive as seqüências LTR e $\psi$, ele pôde ser utilizado diretamente com os plasmídeos pMD2.G e psPAX2 na construção do vetor lentiviral. Entretanto, o plasmídeo pITR DC-LAMP/gag não possui nenhuma das duas seqüências necessárias. Assim, primeiramente foi preciso clonar o gene dc-lamp/gag no plasmídeo-vetor pWPXLd, para então dar procedimento a produção do lentivírus.

Essa etapa de clonagem foi realizada conforme protocolo sugerido pelo fabricante dos reagentes. Primeiramente, $20 \mathrm{U}$ das enzimas de restrição Nhel (New England Biolabs - NEB, Ipswich, MA, EUA) e Kpnl (NEB) foram adicionadas a $20 \mu \mathrm{L}$ do plasmídeo pITR DC-LAMP/gag, enquanto que $20 \mathrm{U}$ da enzima de restrição Pmel (NEB) foi adicionada a $10 \mu \mathrm{L}$ do plasmídeo pWPXLd. Água bidestilada autoclavada foi adicionada às reações até o volume final de $30 \mu \mathrm{L}$, seguindo-se de incubação overnight a $37^{\circ} \mathrm{C}$. No dia seguinte, o volume total das reações foi colocado em gel de agarose a 0,8\% e submetido à corrida eletroforética (110 V, $400 \mathrm{~mA}, 40$ minutos). As bandas correspondentes ao inserto dc-lamp/gag e ao plasmídeo-vetor pWPXLd aberto foram retirados do gel e purificadas utilizando-se o kit GFX'TM PCR DNA and Gel Band Purification Kit (GE Healthcare Biosciences). Em seguida, por se tratar de um corte blunt end, o pWPXLd aberto foi submetido a um processo de desfosforilação, para evitar a re-ligação do plasmídeo, com $2 \mathrm{U}$ da enzima Antartic Phosphatase (NEB) e incubação de 15 minutos a $37^{\circ} \mathrm{C}$, sendo, em seguida, a enzima inativada a $65^{\circ} \mathrm{C}$ por 5 minutos. Enquanto isso, o inserto $d c$-lamp/gag foi preparado para também apresentar uma terminação blunt end por uma reação de polimerização com $100 \mu \mathrm{M}$ de dNTPs, $2 U$ da enzima T4 DNA Polymerase (NEB) por 15 minutos a $12^{\circ} \mathrm{C}$, sendo a reação interrompida a $75^{\circ} \mathrm{C}$ por 20 minutos. Finalmente, foi realizada a reação de ligação utilizando-se $5 \mu \mathrm{L}$ do plasmídeo-vetor, $15 \mu \mathrm{L}$ do inserto (proporção 1:3) e $2 \mathrm{U}$ da enzima T4 DNA Ligase (NEB), num volume final de $25 \mu \mathrm{L}$, incubando-se overnight a $16^{\circ} \mathrm{C}$. 
O novo plasmídeo formado, pGSEF (plasmídeo-vetor pWPXLd + inserto dc-lamp/gag) foi utilizado para transformação de bactérias competentes E.coli $\mathrm{DH} 5 \alpha$, expandido e purificado como descrito anteriormente.

\subsubsection{PRODUÇÃO DOS VETORES LENTIVIRAIS}

Para produção dos vetores lentivirais foi utilizado protocolo sugerido pelo próprio fornecedor dos plasmídeos no repositório Addgene (Prof. Dr. Didier Trono, Laboratory of Virology and Genetics, EPFL, France). Resumidamente, cerca de $8 \times 10^{5}$ células da linhagem HEK 293T foram distribuídas em placas de petri de $5 \mathrm{~cm}$ e deixadas em cultura a $37^{\circ} \mathrm{C}$ e $5 \% \mathrm{CO}_{2}$ por 2 dias em meio DMEM (LGC Biotecnologia, São Paulo, Brasil) suplementado com 10\% SFB e $1 \%$ de piruvato de sódio (GIBCO-BRL), até atingirem confluência de $70 \%$. Uma solução de transfecção foi preparada com $37,5 \mu \mathrm{g}$ do plasmídeo pNL4-3 ${ }^{\mathrm{HSA}}$ pol-env- ou pGSEF, 13,2 $\mu \mathrm{g}$ do plasmídeo pMD2.G e 24,3 $\mu \mathrm{g}$ do plasmídeo psPAX2 (proporção 0,50: 0,176: 0,324; respectivamente), $1,1 \mathrm{~mL}$ de TE (Tris $1 \mathrm{mM}$, EDTA 0,1 mM, pH 8,8), $600 \mu \mathrm{L}$ de água destilada e $188 \mu \mathrm{L}$ de $\mathrm{CaCl}_{2} 2,5 \mathrm{M}$, na qual foram acrescentados 1,9 mL de tampão HBS 2x ( $\mathrm{NaCl} 280$ mM, Hepes 100 mM, Na2HPO 4 1,5 mM; pH 7,12) lentamente e sob agitação. A solução foi incubada por 10 minutos a temperatura ambiente antes de ser adicionada às células ( $750 \mu \mathrm{L} /$ placa) lentamente. Logo pela manhã seguinte, o meio de cultura foi trocado por meio novo pré-aquecido a $37^{\circ} \mathrm{C}$ e ao final da tarde, o sobrenadante, contendo partículas virais, foi coletado e armazenado a $4^{\circ} \mathrm{C}$. Ao longo dos dois dias seguintes o sobrenadante foi coletado em intervalos de 12 horas. Após 3 ou 4 coletas, o material total armazenado foi centrifugado a $450 \mathrm{~g}$ por 10 minutos, filtrado em membrana de $0,22 \mu \mathrm{m}$ (Millipore), aliquotado e estocado a $-80^{\circ} \mathrm{C}$, estando pronto para utilização na transdução das células dendríticas imaturas.

A titulação das partículas lentivirais foi realizada conforme protocolo sugerido pelo Dr. Didier Trono (disponível em http://tronolab.epfl.ch/page58122.html), sendo a quantidade expressa em unidades de transdução (TU). 


\subsection{Esquema de Ativação in vitro de Linfócitos Estimulados por Células}

\section{Dendríticas}

Para os ensaios subseqüentes foram realizadas duas coletas em tubos heparinizados, de 70 e $30 \mathrm{~mL}$ respectivamente, com intervalo de uma semana entre as duas, do sangue periférico dos indivíduos não infectados classificados como realmente expostos ao HIV e com resposta imunológica anti-HIV, segundo o resultado obtido da triagem inicial em resposta a estimulação por antígenos virais. Os indivíduos sadios do grupo controle foram submetidos às mesmas condições de coleta.

As células CD14+ separadas da primeira coleta foram utilizadas para diferenciação em células dendríticas. Na segunda coleta, as células CD14separadas foram colocadas em co-cultivo juntamente com as DCs obtidas da primeira coleta, enquanto que as células CD14+ foram diferenciadas em DCs para serem utilizadas como reforço antigênico no $7^{\circ}$ dia após início do co-cultivo. Finalmente, 72 horas após o reforço de células dendríticas, a resposta imunológica dos linfócitos foi avaliada por ensaios de proliferação e ativação celular e quantificação da produção de citocinas. O esquema abaixo ilustra essa seqüência de experimentos.

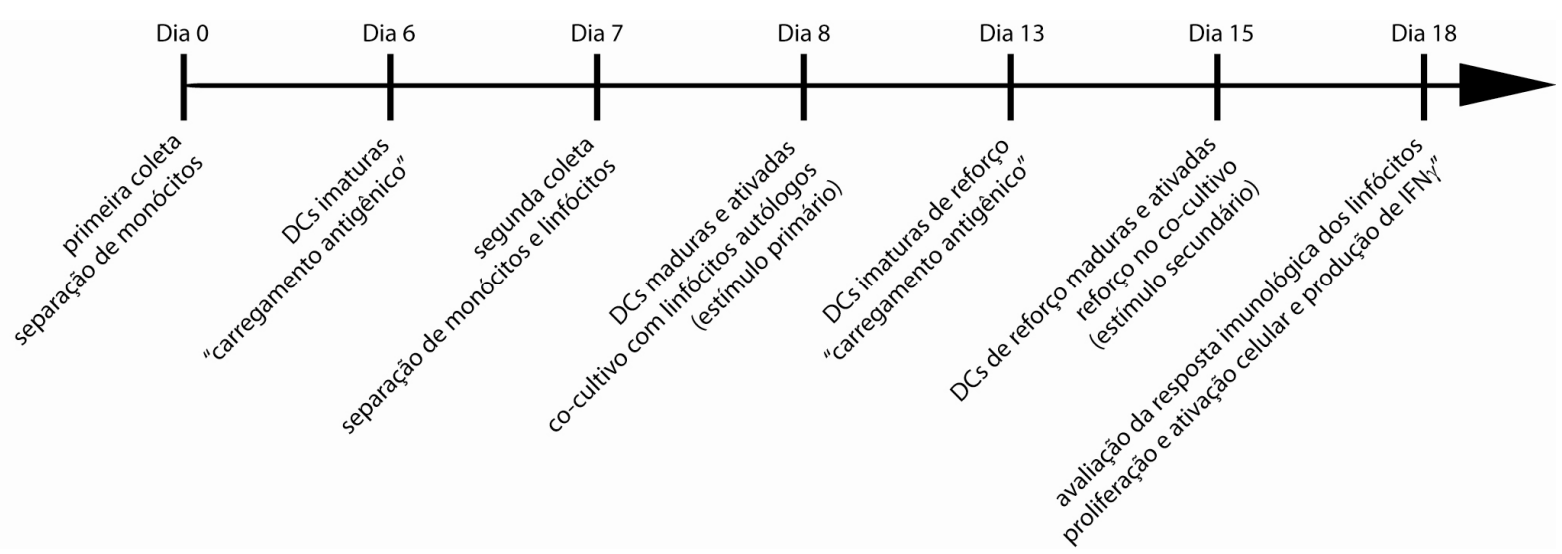

Figura 6 - Esquema dos experimentos de obtenção das células dendríticas e co-cultivo com linfócitos autólogos. Representação esquemática da seqüência de experimentos para obtenção de células dendríticas a partir de monócitos e co-cultivo com linfócitos autólogos, desde 0 dia 0 correspondente a $1^{\underline{a}}$ coleta sanguínea até 0 dia 18 correspondente aos ensaios de citometria de fluxo e proliferação celular. 


\subsubsection{Geração de Células Dendríticas}

As células dendríticas foram diferenciadas a partir de monócitos do sangue periférico segundo protocolo descrito por Romani, et al. (1996) e Sallusto e Lanzavecchia (1994), com algumas modificações.

Células mononucleares foram isoladas de sangue periférico por centrifugação com gradiente de Ficoll-Paque (GE Healthcare Bioscience). Em seguida, os monócitos foram purificados por seleção magnética positiva de células expressando a molécula CD14 (VarioMACS, Miltenyi Biotec, Bergisch Gladbach, Alemanha), segundo instruções do fabricante. Em resumo, as $\mathrm{CMN}$ foram incubadas com microesferas de ferro e açúcar conjugadas a anticorpo monoclonal anti-CD14 humano e, após lavagem, acondicionadas em colunas LS ou MS (Miltenyi Biotec). Enquanto expostas a um campo magnético, a coluna foi lavada repetidas vezes com tampão apropriado para retirada da fração de células CD14- (constituída principalmente por linfócitos e, como tal, para efeito de simplicidade será denominada a partir de agora simplesmente como linfócitos), as quais foram congeladas ao fim do processo de separação. Então, a coluna foi removida do campo magnético e as células CD14+ (monócitos) foram eluídas, lavadas e cultivadas em meio de cultura AIM-V sem soro $\left(\right.$ Invitrogen $^{\mathrm{TM}}$ ), suplementado com $50 \mathrm{ng} / \mathrm{mL}$ de IL-4 (PeproTech) e $50 \mathrm{ng} / \mathrm{mL}$ de GM-CSF (PeproTech), em placas de cultura de 24 poços na concentração de $2 \times 10^{6}$ células/poço. No $3^{\circ}$ dia de cultura, foi adicionado à cultura um reforço de IL-4 e GM-CSF nas mesmas concentrações. No 6 o dia, os monócitos encontravam-se totalmente diferenciados em DCs no estado imaturo.

\subsubsection{Pulso e Maturação de Células Dendríticas Imaturas}

No $6^{\circ}$ dia do processo de diferenciação dos monócitos, quando as células já se apresentavam como células dendríticas no estado imaturo, as DCs foram "carregadas" com os diversos produtos antigênicos do HIV a serem testados.

Para isso, primeiramente foram retirados cerca de $70 \%$ do meio de cultura (os quais foram armazenados a $-80^{\circ} \mathrm{C}$ para posterior dosagem de citocinas, deixando $\mathrm{o}$ máximo de $300 \mu \mathrm{L}$ (poço). Em seguida, as células foram infectadas com o pool de subtipos do HIV-1 (109 partículas virais), pulsadas com a proteína de $55 \mathrm{kDa}$ (p55Gag) do HIV-1 $1_{\text {IIIB }}(5 \mu \mathrm{g})$ ou transduzidas com os vetores lentivirais de 
pNL4-3 ${ }^{\text {HSA }}$ pol-env- ou pGSEF (100 TU) e incubadas por no mínimo 2 horas em estufa a $37^{\circ} \mathrm{C}$ e $5 \% \mathrm{CO}_{2}$. Como controle negativo para os ensaios posteriores, em um dos poços da cultura nada foi adicionado, deixando-o apenas com o meio AIM-V. Após esse período de incubação, as células foram suavemente lavadas na própria placa para remoção do excesso de antígeno e colocadas novamente em cultura por mais 48 horas com $1 \mathrm{~mL}$ de meio AIM-V suplementado com $50 \mathrm{ng} / \mathrm{mL}$ de TNFa, IL-4 e GM-CSF, $10 \mathrm{ng} / \mathrm{mL}$ de IL-1ß e $100 \mathrm{ng} / \mathrm{mL}$ de IL-6 (PeproTech) para realização do processo de maturação.

\subsubsection{Caracterização Fenotípica e Funcional de Células Dendríticas}

As células dendríticas diferenciadas a partir de monócitos de sangue periférico foram analisadas fenotipicamente com relação à expressão das moléculas de superfície CD11c (marcador de células dendríticas da linhagem mielóide), CD14 (marcador de células da linhagem monocítica, ausente em DCs mielóides), HLA-DR (molécula apresentadora de antígenos, presente em maiores quantidades em DCs maduras), CD86 (molécula co-estimulatória constitutiva porém mais expressa em DCs maduras), CD80 (molécula co-estimulatória expressa sob ativação celular), CD83 (marcador de ativação de DCs) e CD1a (molécula relacionada a apresentação de antígenos lipídicos, presentes ou não em DCs derivadas de monócitos [CHANG et al., 2000; DUPERRIER et al., 2000; XIA e KAO, 2002]) e funcionalmente quanto a secreção das citocinas IL-10 e IL-12p70 e da quimiocina MIP-1 $\alpha$, em dois momentos distintos: no $6^{\circ}$ dia de cultura, em seu estado imaturo e no $8^{\circ}$ dia, no estado maduro.

\subsubsection{Co-cultivo dos Linfócitos e Células Dendríticas}

As CMN foram isoladas por gradiente de Ficoll-Paque e as células dendríticas foram obtidas conforme descrito nos itens anteriores. Após 8 dias, período necessário para a diferenciação, "carregamento" antigênico e maturação das DCs, os linfócitos frescos (provenientes da segunda coleta sanguínea) foram cocultivados em placas de 48 poços na presença das células dendríticas (obtidas da primeira coleta sanguínea) infectadas, pulsadas, transduzidas ou apenas maduras (controle negativo) na proporção de 5 linfócitos para 1 DC durante 7 dias em meio AIM-V (Invitrogen ${ }^{\mathrm{TM}}$ ) suplementado com $10 \%$ de SAB a $37^{\circ} \mathrm{C}$ e $5 \% \mathrm{CO}_{2}$, no intuito de promover a seleção de clones de linfócitos T específicos para antígenos do HIV. No $7^{\circ}$ dia, as culturas foram re-estimuladas pela adição de novas DCs (diferenciadas 
da segunda coleta sanguínea) "carregadas" (ou não) com os mesmos antígenos na proporção de 20:1 (linfócitos : DC). Ainda nesse dia, aproximadamente 2,5 × $10^{5}$ células da co-cultura foram retiradas da placa de 48 poços e cultivadas, em triplicatas para cada estímulo de DC, numa placa de 96 poços de fundo chato para realização do ensaio de proliferação celular.

\subsubsection{Avaliação dos Linfócitos T Estimulados por Células Dendríticas}

Setenta e duas horas após a adição do reforço de DCs, a resposta imunológica desenvolvida pelos linfócitos $T$ estimulados pelas células dendríticas apresentando os diferentes produtos antígenos do HIV foi avaliada pelo ensaio de proliferação celular e pela expressão da molécula de superfície CD38 (marcadora de ativação celular) e detecção intracelular de IFN $\gamma$ por citometria de fluxo. Como controle positivo interno desse ensaio foi utilizado uma alíquota dos linfócitos, estimulados por ionomicina $(1 \mu \mathrm{g} / \mathrm{mL}$, Sigma-Aldrich) e phorbol myristate acetate (PMA, $50 \mathrm{ng} / \mathrm{mL}$, Sigma-Aldrich) durante 18 horas. Vinte horas antes do término do co-cultivo, $10 \mu \mathrm{g} / \mathrm{mL}$ de brefeldina A (Sigma-Aldrich) foi acrescentado para inibir a secreção do IFN $\gamma$ sintetizado.

Ainda, alíquotas de $50 \mu \mathrm{L}$ de sobrenadante do co-cultivo foram coletadas no mesmo período para quantificação da secreção das citocinas IFN $\gamma$ e IL-10 por ELISA (DuoSet).

\subsection{Ensaio de Citometria de Fluxo}

Todos os ensaios de citometria de fluxo foram adquiridos em citômetro BD FACSCalibur $^{T M}$ (BD Biosciences, San Jose, CA, EUA), composto por um laser de argônio de $488 \mathrm{~nm}$, e analisados pelo software FlowJo v.7.5.5 para PC (Tree Star, Inc., Ashland, OR, EUA).

\subsubsection{Marcação de Moléculas de Superfície das Células Dendríticas}

A análise de expressão das moléculas de superfície características de cada etapa dos processos de diferenciação dos monócitos em células dendríticas e de ativação e maturação das mesmas foi realizada utilizando-se os seguintes anticorpos conjugados com fluorocromos (BD Pharmingen ${ }^{\mathrm{TM}}$ ): anti-CD1a PE, antiCD11c PECy5, anti-CD14 PE, anti-CD80 PE, anti-CD83 FITC, anti-CD86 FITC e anti-HLA-DR FITC (juntamente com seus respectivos controles isotípicos). 
Para realização deste ensaio, alíquotas de DCs (aproximadamente $1 \times 10^{5}$ células) foram coletadas no $6^{\circ}$ (estado imaturo) e $8^{\circ}$ dias de cultura (maduras e ativadas). As células foram ressuspendidas em $100 \mu \mathrm{L}$ de tampão PBS $0,1 \%$ BSA em tubos plásticos de citometria e $5 \mu \mathrm{L}$ de cada anticorpo foram adicionados aos respectivos tubos. Após incubação por 30 minutos a $4^{\circ} \mathrm{C}$ no escuro, o material foi lavado com solução PBS-Azida por 5 minutos a $350 \mathrm{~g}$ e ressuspendido em volume apropriado de tampão isotônico, estando prontos para aquisição imediata no citômetro de fluxo. Quando da impossibilidade de realização da aquisição das amostras no mesmo dia, as células foram obrigatoriamente fixadas por 15 minutos a temperatura ambiente e ao abrigo da luz com $100 \mu \mathrm{L}$ do Reagente $\mathrm{A}$ (solução de paraformaldeído) do kit Fix\&Perm (Invitrogen ${ }^{\mathrm{TM}}{ }_{\text {, }}$ ), seguido de lavagem com tampão PBS-Azida para remoção do excesso de reagente fixador.

A combinação dos anticorpos e controles foi realizada da seguinte maneira:

- Tubo 1: controle isotípico

- Tubo 2: compensação de FITC

- Tubo 3: compensação de PE

- Tubo 4: compensação de PECy5

- Tubo 5: anti-HLA-DR / anti-CD14 / anti-CD11c

- Tubo 6: anti-CD86 / anti-CD80 / anti-CD11c

- Tubo 7: anti-CD83 / anti-CD1a / anti-CD11c

\subsubsection{Marcação dos Linfócitos T}

Para avaliar a ativação dos linfócitos $T$ estimulados por células dendríticas apresentando antígenos do HIV foram utilizados os anticorpos anti-CD3 PECy5, anti-CD8 PE, anti-CD38 PE (BD Pharmingen ${ }^{\mathrm{TM}}$ ) e anti-IFN $\gamma$ PE (Invitrogen ${ }^{\mathrm{TM}}$ ).

Setenta e duas horas após o reforço de DCs no co-cultivo, os linfócitos foram retirados da placa, lavados com tampão PBS 0,1\% BSA e distribuídos em tubos plásticos de citometria (100 $\mu \mathrm{L} /$ tubo). Após marcação das moléculas de superfície CD3, CD8 e CD38 seguindo o mesmo procedimento descrito no item anterior para DCs, os linfócitos foram fixados e permeabilizados utilizando os reagentes Fix\&Perm (Invitrogen $^{\mathrm{TM}}$ ) seguindo as instruções do fabricante. 
A combinação dos anticorpos e controles foi realizada da seguinte maneira:

- Tubo 1: controle isotípico

- Tubo 2: compensação FITC

- Tubo 3: compensação PE

- Tubo 4: compensação PECy5

- Tubo 5: anti-CD8 / anti-CD38 / anti-CD3

- Tubo 6: anti-CD8 / anti-IFN / anti-CD3

- Tubo 7: controle positivo anti-CD8 / anti-IFN / anti-CD3

\subsubsection{Análise dos Dados de Citometria de Fluxo}

A análise da expressão das moléculas CD14, HLA-DR, CD86, CD80, CD83 e CD1a nas células dendríticas foi realizada levando-se em conta apenas células CD11c+, selecionadas a partir de um gate específico segundo características de tamanho e complexidade citoplasmática, excluindo-se células mortas e debris celulares, com no mínimo 20.000 eventos adquiridos. O esquema da figura 7 representa esse tipo de análise. 


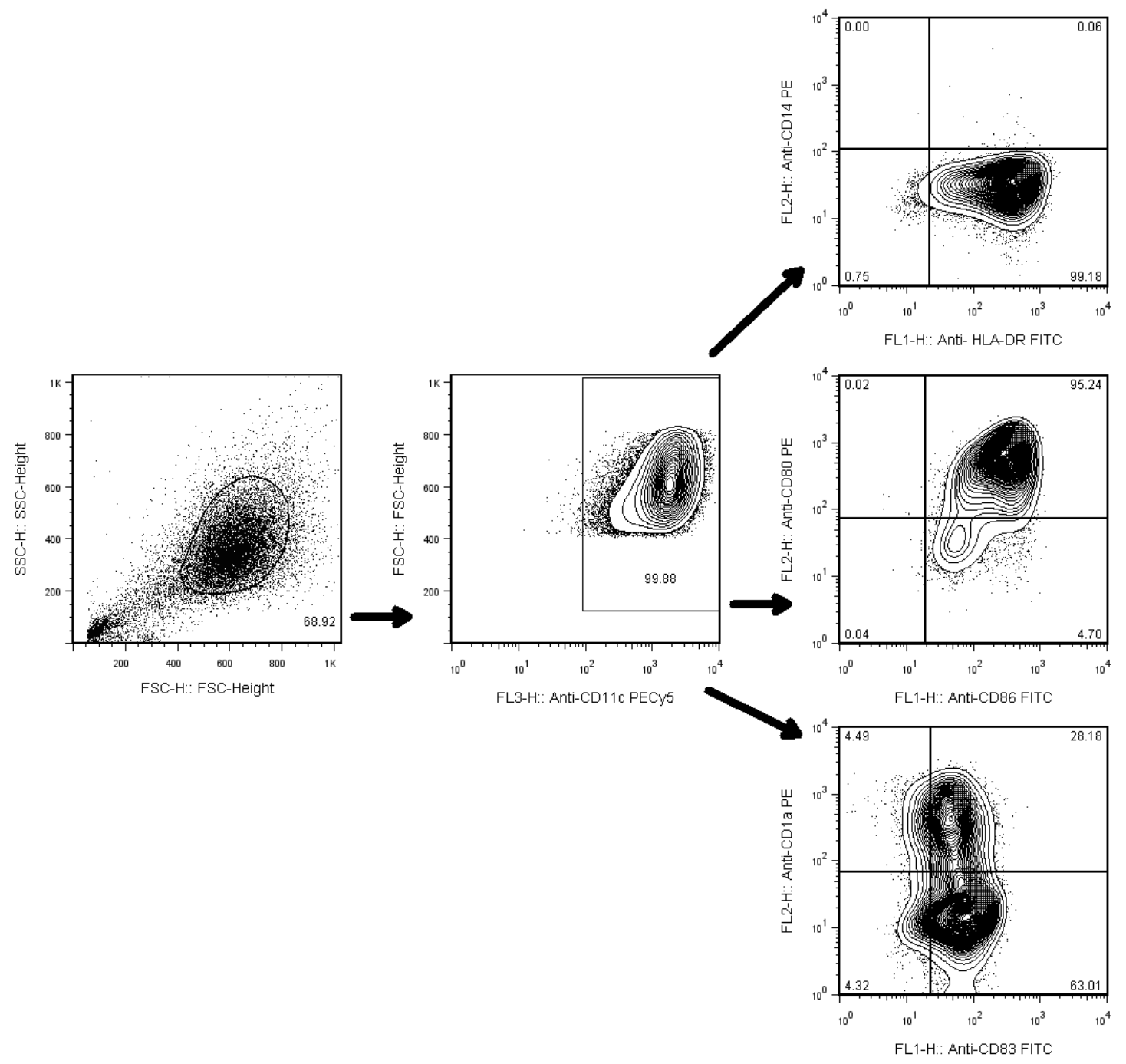

Figura 7 - Esquema de análise da citometria de fluxo de células dendríticas. Representação esquemática da análise dos dados de citometria de fluxo das células dendríticas maduras e imaturas. Primeiramente, foi realizado um gate segundo características de tamanho e complexidade celular (gráfico da esquerda). A seguir, um novo gate selecionando apenas células CD11C+ (gráfico central). Essas células foram então analisadas quanto a expressão das moléculas CD14, HLA-DR, CD86, CD80, CD83 e CD1a (gráficos da direita).

A expressão do marcador de ativação (molécula CD38) e a produção de IFN $\gamma$ foram analisadas apenas em linfócitos T (células CD3+), selecionados a partir de um gate específico segundo características de tamanho e complexidade citoplasmática, excluindo-se células mortas e debris celulares, com no mínimo 200.000 eventos adquiridos. $O$ esquema da figura 8 ilustra a análise empregada. 


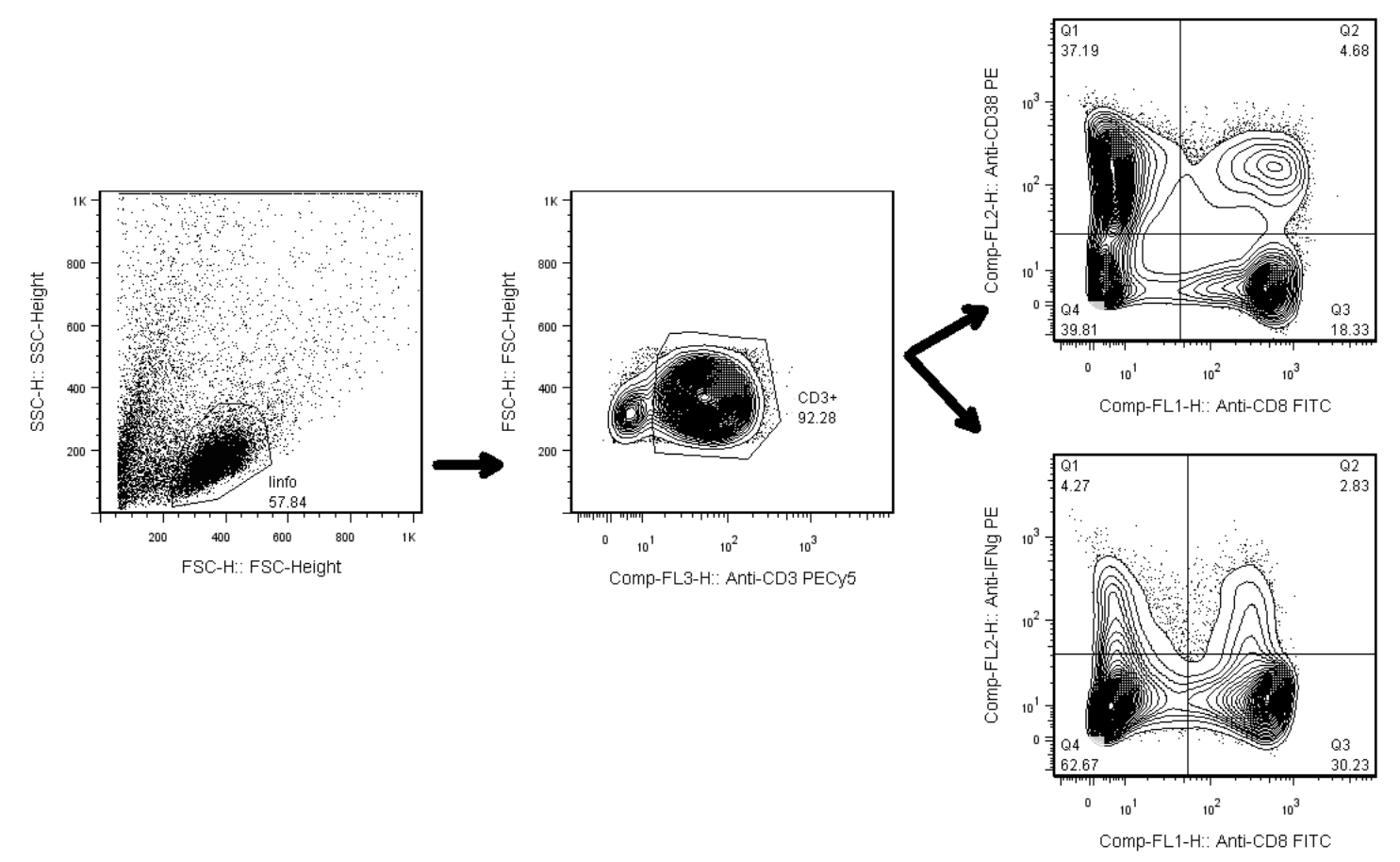

Figura 8 - Esquema de análise da citometria de fluxo de linfócitos. Representação esquemática da análise dos dados de citometria de fluxo dos linfócitos $T$ em co-cultivo com células dendríticas autólogas. Primeiramente, foi realizado um gate segundo características de tamanho e complexidade celular (gráfico da esquerda). A seguir, um novo gate selecionando apenas células CD3+ (gráfico central). Essas células foram então analisadas quanto a expressão das moléculas CD8 e CD38 e a produção de IFN $\gamma$ (gráficos da direita).

\subsection{Ensaio de ELISA para Detecção de Citocinas e Quimiocina}

As citocinas IFN $\gamma$ e IL-10 foram dosadas em alíquotas de sobrenadante do co-cultivo linfócitos/DCs, enquanto que as citocinas IL-10 e IL-12p70 e a quimiocina MIP-1 $\alpha$ foram quantificadas no sobrenadante das culturas de células dendríticas imaturas e maduras. Para tanto, foram utilizados os kits de ELISA DuoSet (R\&D Systems), seguindo as instruções do fabricante.

Resumidamente, placas de 96 poços de meia-área (Costar) foram sensibilizadas com anticorpo anti-citocina (anticorpo de captura) e incubadas a temperatura ambiente (TA) overnight. No dia seguinte, primeiramente as placas foram lavadas com tampão de lavagem próprio de cada kit e incubadas a TA por pelo menos uma hora com tampão de bloqueio (PBS 1\% BSA). Em seguida, seguiram-se as seguintes etapas de incubação sempre a TA e ao abrigo da luz, intercaladas com etapas de lavagem: 2 horas com as amostras e curva-padrão, 2 horas com anticorpo anti-citocina conjugado com biotina (anticorpo de detecção), 20 minutos com solução de estreptoavidina conjugada a peroxidase e 20 minutos com 
solução de substrato TMB. A reação colorimétrica foi interrompida com solução de ácido sulfúrico $2 \mathrm{~N}$ e as densidades ópticas determinadas a $450 \mathrm{~nm}$.

A concentração das citocinas foi determinada pelo software GraphPad Prism 5.1 (GraphPad Software, Inc., La Jolla, CA, EUA) utilizando o modelo de regressão não linear logístico de 4 parâmetros (4-PL) a partir da curva-padrão conhecida, semelhante ao exemplo representado abaixo da citocina IL-10.

\section{IL-10}

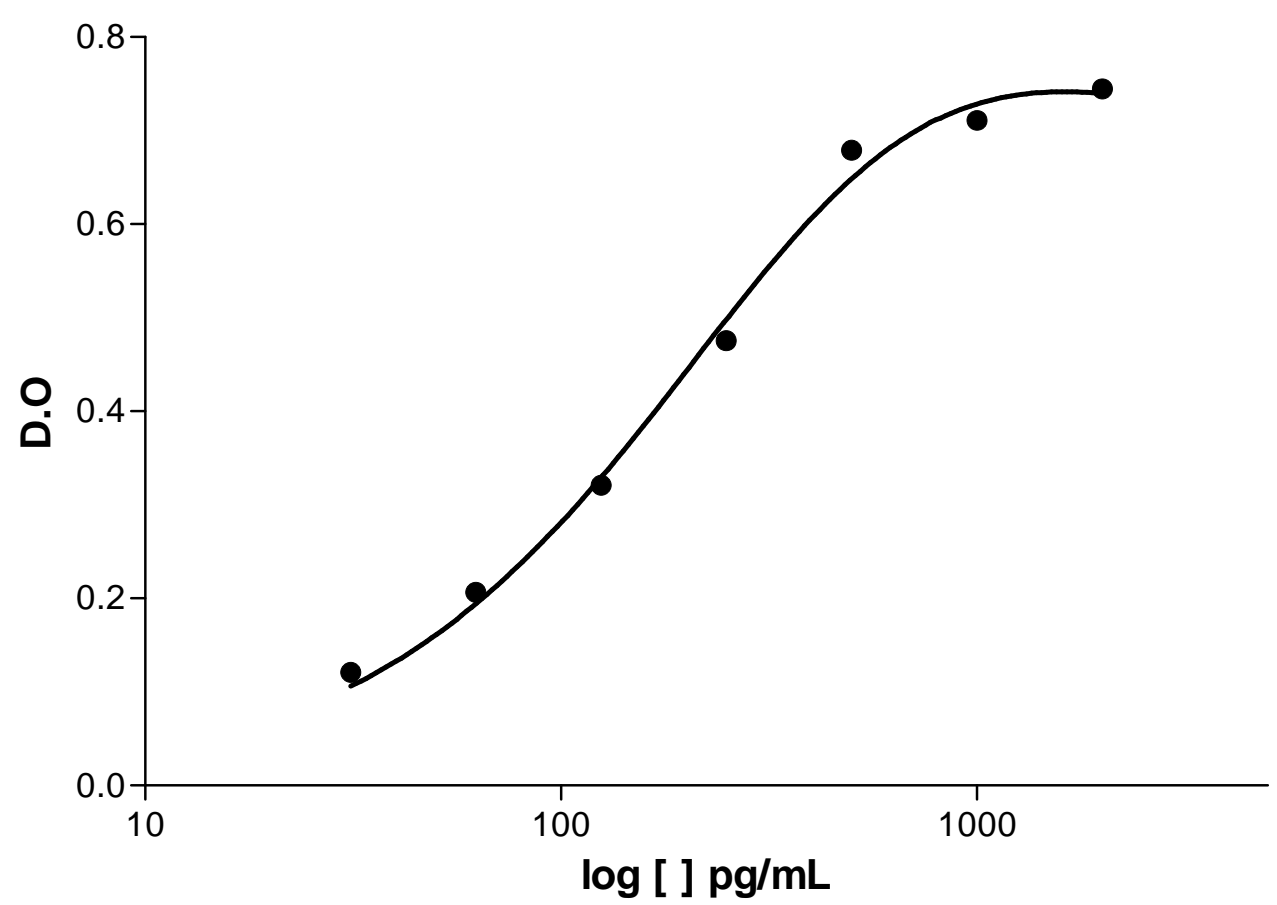

Figura 9 - Curva-padrão de IL-10. Exemplo de uma curva-padrão obtida em um experimento de ELISA para detecção da citocina IL-10, analisada pelo modelo de regressão não linear logístico de 4 parâmetros (4-PL) no software GraphPad Prism 5.1. [ ], concentração.

\subsection{Análise Estatística}

A análise estatística dos dados aqui apresentados foi realizada pelo software GraphPad Prism 5.1 (GraphPad Software, Inc.) utilizando-se o testes não paramétricos de Kruskal-Wallis com pós-teste de múltiplas comparações de Dunn para comparação entre amostras do mesmo grupo (expressão de CD38 de DCs maduras e pulsadas com p55Gag de par discordante) e de Mann Whitney quando comparadas amostras dos dois grupos (produção de IFN $\gamma$ das DCs pulsadas com p55Gag de par discordante e indivíduo controle). 


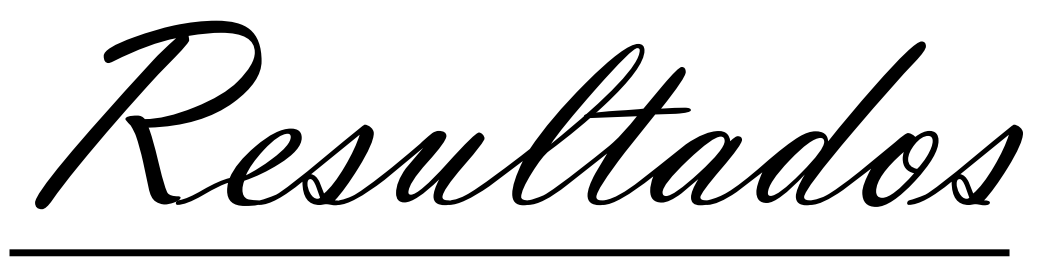




\section{RESULTADOS}

\subsection{Triagem dos Indivíduos Expostos ao HIV Não Infectados}

Pares discordantes são indivíduos expostos ao HIV, porém não infectados, que desenvolvem resposta imune específica ao vírus quando estimulados com antígenos virais in vitro (SUY et al., 2007). Nossa coorte, composta de pessoas com esse perfil, foi primeiramente avaliada mediante ensaios imunológicos de proliferação celular e produção de IFN $\gamma$ frente à estimulação por antígenos do HIV, de modo a selecionar apenas aqueles que efetivamente apresentaram resposta imune contra 0 vírus. A tabela 1 apresenta os resultados obtidos nesses dois ensaios imunológicos.

Dos 20 pares discordantes avaliados, apenas 10 satisfizeram as condições necessárias para classificação como "respondedores" a antígenos do HIV, isto é, proliferação celular maior que $1000 \mathrm{cpm}$ e I.E maior que 2, ou produção de IFN $\gamma$ maior que $100 \mathrm{pg} / \mathrm{mL}$ sobre a produção basal. Todavia, desses indivíduos selecionados, 2 optaram por abandonar voluntariamente o estudo (PD2 e PD4) e 1 não foi possível o contato de retorno até o momento da finalização dessa dissertação (PD18). Os outros 7 (PDs 1, 3, 14, 15, 16, 17 e 20) foram re-convocados e efetivamente incluídos no projeto.

Tabela 1 - Resultados obtidos na triagem inicial dos pares discordantes pelos ensaios de proliferação celular e produção de IFN $\gamma$ em resposta a estimulação por antígenos do HIV.

\begin{tabular}{c|c|c|c|c|c}
\hline Nome & $\begin{array}{c}\text { Proliferação } \\
\text { p55G } \\
\text { (cpm / I.E) }\end{array}$ & $\begin{array}{c}\text { Proliferação } \\
\text { pool viral } \\
\text { (cpm / I.E) }\end{array}$ & $\begin{array}{c}\text { Produção de } \\
\text { IFN } \mathbf{p 5 5 G a g - ~} \\
\text { produção basal } \\
\text { (pg/mL) }\end{array}$ & $\begin{array}{c}\text { Produção de } \\
\text { IFN } \mathbf{p o o l ~ v i r a l ~ - ~} \\
\text { produção basal } \\
\text { (pg/mL) }\end{array}$ & Status \\
\hline PD1 & $1637,2 / 2,9$ & $1005,8 / 1,8$ & 1,2 & 2,0 & $\begin{array}{c}\text { Respondedor, } \\
\text { inclúdo no } \\
\text { projeto }\end{array}$ \\
\hline PD2 & $2804,9 / 0,67$ & $6532,4 / 1,9$ & NR & NR & $\begin{array}{c}\text { Respondedor, } \\
\text { abandonou o } \\
\text { estudo }\end{array}$ \\
\hline PD3 & $2667,5 / 3,3$ & $2144,5 / 2,7$ & 0,0 & 0,0 & $\begin{array}{c}\text { Respondedor, } \\
\text { incluído no } \\
\text { projeto }\end{array}$ \\
\hline PD4 & $1115,7 / 3,3$ & $1123,5 / 3,3$ & NR & NR & $\begin{array}{c}\text { Respondedor, } \\
\text { abandonou o } \\
\text { estudo }\end{array}$ \\
\hline
\end{tabular}




\begin{tabular}{|c|c|c|c|c|c|}
\hline PD5 & $835,0 / 0,8$ & $1334,1 / 1,3$ & 84,8 & 0,0 & Não respondedo \\
\hline PD6 & $464,0 / 1,7$ & $267,4 / 1,02$ & 0,0 & 0,0 & Não respondedo \\
\hline PD7 & 116,5 / 0,5 & $157,7 / 0,7$ & 42,4 & 0,0 & Não respondedo \\
\hline PD8 & $314,7 / 0,5$ & $81,8 / 0,2$ & 0,0 & 0,0 & Não respondedo \\
\hline PD9 & 350,2 / 1,2 & $441,4 / 1,6$ & 0,0 & 0,0 & Não respondedo \\
\hline PD10 & 279,6 / 0,8 & $248,4 / 0,8$ & 0,0 & 0,0 & Não respondedo \\
\hline PD11 & 375,2 / 0,9 & $381,8 / 0,9$ & 0,0 & 58,3 & Não respondedo \\
\hline PD12 & 186,3 / 1,2 & $573,6 / 3,7$ & 0,6 & 0,6 & Não respondedo \\
\hline PD13 & $1009,8 / 1,7$ & $541,6 / 0,9$ & 1,0 & 0,0 & Não respondedor \\
\hline PD14 & $5574,3 / 2,2$ & $2278,4 / 0,9$ & 224,4 & 0,0 & $\begin{array}{l}\text { Respondedor, } \\
\text { incluído no } \\
\text { projeto }\end{array}$ \\
\hline PD15 & 4342,6 / 3,0 & $1108,1 / 0,8$ & 226,0 & 16,2 & $\begin{array}{l}\text { Respondedor, } \\
\text { incluído no } \\
\text { projeto }\end{array}$ \\
\hline PD16 & $3917,7 / 9,5$ & $1376,1 / 3,3$ & 404,9 & 0,0 & $\begin{array}{l}\text { Respondedor, } \\
\text { incluído no } \\
\text { projeto }\end{array}$ \\
\hline PD17 & 1648,4 / 4,0 & $2121,2 / 5,1$ & 11,8 & 38,4 & $\begin{array}{l}\text { Respondedor, } \\
\text { incluído no } \\
\text { projeto }\end{array}$ \\
\hline PD18 & 1204,2 / 2,3 & 1218,2 / 2,3 & 100,7 & 11,5 & $\begin{array}{l}\text { Respondedor, } \\
\text { não incluído no } \\
\text { projeto }\end{array}$ \\
\hline PD19 & 495,0 / 1,4 & $425,6 / 1,2$ & 1,3 & 11,4 & Não respondedo \\
\hline PD20 & 1727,2 / 4,4 & 2466,5 / 6,2 & 1316,7 & 197,7 & $\begin{array}{l}\text { Respondedor, } \\
\text { incluído no } \\
\text { projeto }\end{array}$ \\
\hline
\end{tabular}

Da mesma forma, os indivíduos não expostos do grupo controle foram avaliados pelos mesmos ensaios, sendo os dados apresentados na tabela 2 .

Tabela 2 - Resultados obtidos na triagem inicial dos indivíduos sadios não expostos ao HIV pelos ensaios de proliferação celular e produção de IFN $\gamma$ em resposta a estimulação com antígenos do HIV.

\begin{tabular}{|c|c|c|c|c|c|}
\hline Nome & $\begin{array}{c}\text { Proliferação } \\
\text { p55Gag } \\
\text { (cpm / I.E) }\end{array}$ & $\begin{array}{c}\text { Proliferação } \\
\text { pool viral } \\
\text { (cpm / I.E) }\end{array}$ & $\begin{array}{l}\text { Produção de } \\
\text { IFN } \gamma \text { p55Gag - } \\
\text { produção basal } \\
\quad(\mathrm{pg} / \mathrm{mL})\end{array}$ & $\begin{array}{c}\text { Produção de } \\
\text { IFN } \gamma \text { pool viral - } \\
\text { produção basal } \\
(\mathrm{pg} / \mathrm{mL})\end{array}$ & Status \\
\hline INE1 & $229,3 / 1,7$ & 823,5 / 0,9 & 0,0 & 47,0 & Não respondedor \\
\hline
\end{tabular}


continuação

\begin{tabular}{c|c|c|c|c|l}
\hline INE2 & $369,4 / 2,1$ & $810,7 / 1,3$ & 11,4 & 13,6 & Não respondedor \\
\hline INE3 & $282,6 / 0,5$ & $495,7 / 0,8$ & 6,1 & 0,0 & Não respondedor \\
\hline IE4 & $382,1 / 0,9$ & $573,1 / 1,4$ & 0,0 & 38,9 & Não respondedor \\
\hline
\end{tabular}

\subsection{Pool de Subtipos do HIV-1}

Para formação do pool viral, subtipos do HIV-1 foram adquiridos junto ao programa de pesquisa e reagentes do HIV do $\mathrm{NIH}$, expandidos em CMN ativadas de doadores sadios, inativados quimicamente por AT-2 e misturados numa única solução na mesma proporção. Foram também utilizadas amostras já inativadas dos subtipos B e F, cedidas pela Dr. Telma Oshiro.

A Tabela 3 apresenta os dados relativos à composição do pool. Como o HIV-1 apresenta duas cópias de RNA, a quantidade total de partículas virais foi determinada pela seguinte fórmula: $n^{0}$ partículas virais = cópias de $R N A / m L \div 2$. Assim, o pool foi composto pela mesma quantidade de partículas virais de cada subtipo, de acordo com a menor concentração encontrada, isto é, $4,64 \times 10^{9}$ partículas/mL (amostra dos subtipos B e F), resultando em 23 alíquotas de pool viral de aproximadamente $1 \times 10^{9}$ partículas $/ \mathrm{mL}\left(4,64 \times 10^{9} \times 5\right.$ amostras inativadas).

Tabela 3 - Composição do pool de subtipos do HIV-1 inativados por AT-2.

\begin{tabular}{c|c|c}
\hline Subtipo Viral & $\begin{array}{c}\text { Cópias de RNA/mL } \\
\left(\mathbf{x 1 0 ^ { 6 } )}\right.\end{array}$ & $\begin{array}{c}\mathbf{n}^{\mathbf{0}} \text { partículas virais/mL } \\
\left(\mathbf{\times 1 0 ^ { 9 }}\right)\end{array}$ \\
\hline A & 17074 & 8,54 \\
\hline B e F & 9279 & 4,64 \\
\hline C & 36610 & 18,30 \\
\hline D & 18286 & 9,14 \\
\hline G & 17295 & 8,65 \\
\hline
\end{tabular}




\subsection{Expansão Plasmidial}

A expansão dos plasmídeos pNL4-3 ${ }^{\text {HSA }}$ pol-env-, pITR DC-LAMP/gag, pMD2.G, psPAX2 e pWPXLd foi realizada em sistema bacteriano (E.coli DH5 $\alpha$ ) seguida de extração e purificação pelo kit Endofree ${ }^{\circledR}$ Plasmid Maxi Kit (QIAGEN). Após esses processos, a concentração dos plasmídeos foi quantificada no aparelho NanoDrop® ND-1000.

Até três expansões de cada plasmídeo foram realizadas sendo obtidas as seguintes concentrações finais:

$$
\begin{array}{ll}
\text { - } & \text { pNL4-3 }{ }^{\text {HSA }} \text { pol-env- }-53,5 \mathrm{ng} / \mu \mathrm{L}(1800 \mu \mathrm{L}) \\
\text { - } & \text { pITR DC-LAMP/gag }-167,1 \mathrm{ng} / \mu \mathrm{L}(1200 \mu \mathrm{L}) \\
\text { - } & \text { pMD2.G }-555,4 \mathrm{ng} / \mu \mathrm{L}(600 \mu \mathrm{L}) \\
\text { - } & \operatorname{psPAX2}-666,2 \mathrm{ng} / \mu \mathrm{L}(600 \mu \mathrm{L}) \\
\text { - } & \text { pWPXLd }-219,6 \mathrm{ng} / \mu \mathrm{L}(600 \mu \mathrm{L})
\end{array}
$$

Todos os plasmídeos foram avaliados quanto a sua integridade e pureza (ausência de DNA cromossômico bacteriano) em corrida eletroforética com gel de agarose $0,8 \%$.
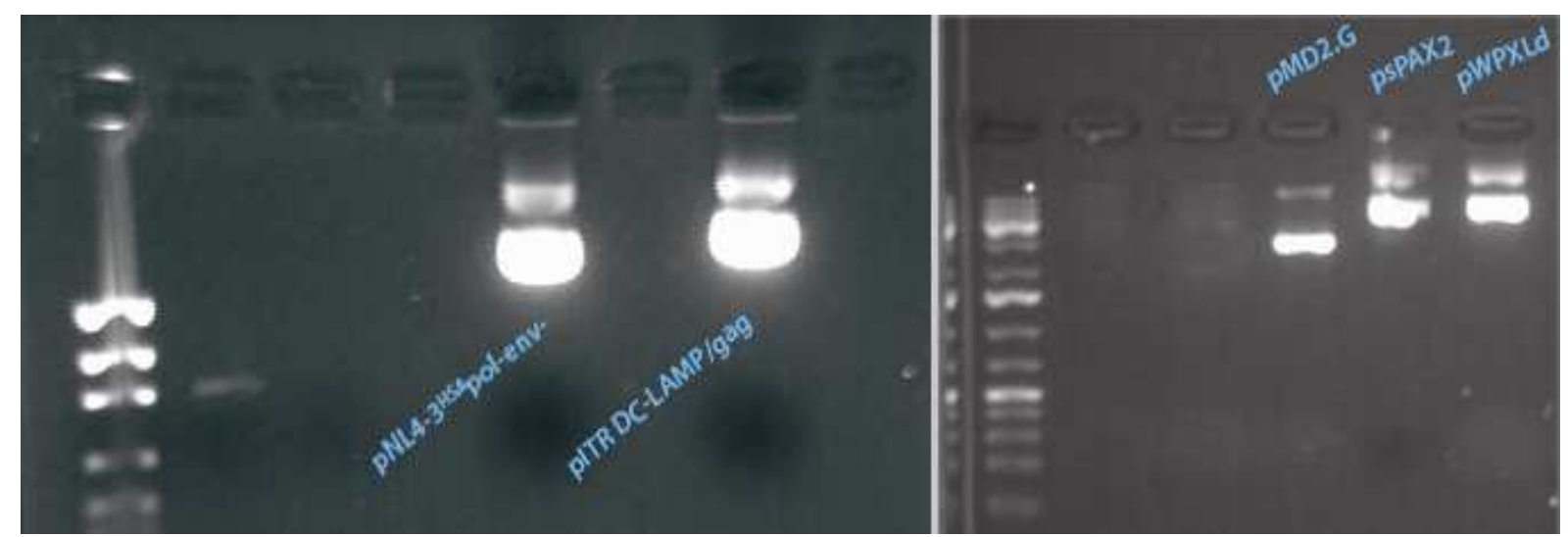

Figura 10 - Eletroforese dos plasmídeos expandidos. Gel de agarose representando corrida eletroforética dos plasmídeos pNL4-3 ${ }^{\text {HSA }}$ pol-env-, pITR DC-LAMP/gag, pMD2.G, psPAX2 e pWPXLd. Bandas superiores representam a forma coiled dos plasmídeos. Notar ausência de "arraste" e outras bandas.

\subsection{Produção dos Vetores Lentivirais}

Com objetivo de transpor o problema de inserção dos plasmídeos pNL4-3 ${ }^{\text {HSA }}$ pol-env- e pITR DC-LAMP/gag nas células dendríticas imaturas, foi 
utilizado um sistema de vetor lentiviral baseado em HIV e pseudotipado com VSV-G. Esse sistema cria partículas virais, cujo material genético é composto por uma cópia de RNA do gene de interesse, capazes de transduzir células primárias que não se replicam (como as células dendríticas humanas). Uma vez dentro das células, a seqüência de RNA é retrotranscrita em DNA e integrada ao genoma celular. Assim, o gene é transcrito e traduzido em proteínas como se fosse da própria célula.

No entanto, o plasmídeo pITR DC-LAMP/gag não possui os sinais necessários (sequências LTR e $\psi$ ) para a correta construção do vetor viral. Assim, primeiramente foi necessário clonar o gene dc-lamp/gag no plasmídeo-vetor pWPXLd, para então dar procedimento a produção do lentivírus. Como demonstra a figura 11, essa etapa de clonagem foi realizada com sucesso e o plasmídeo resultante pGSEF (plasmídeo-vetor pWPXLd + inserto dc-lamp/gag) foi corretamente expandido e purificado conforme protocolos já descritos.
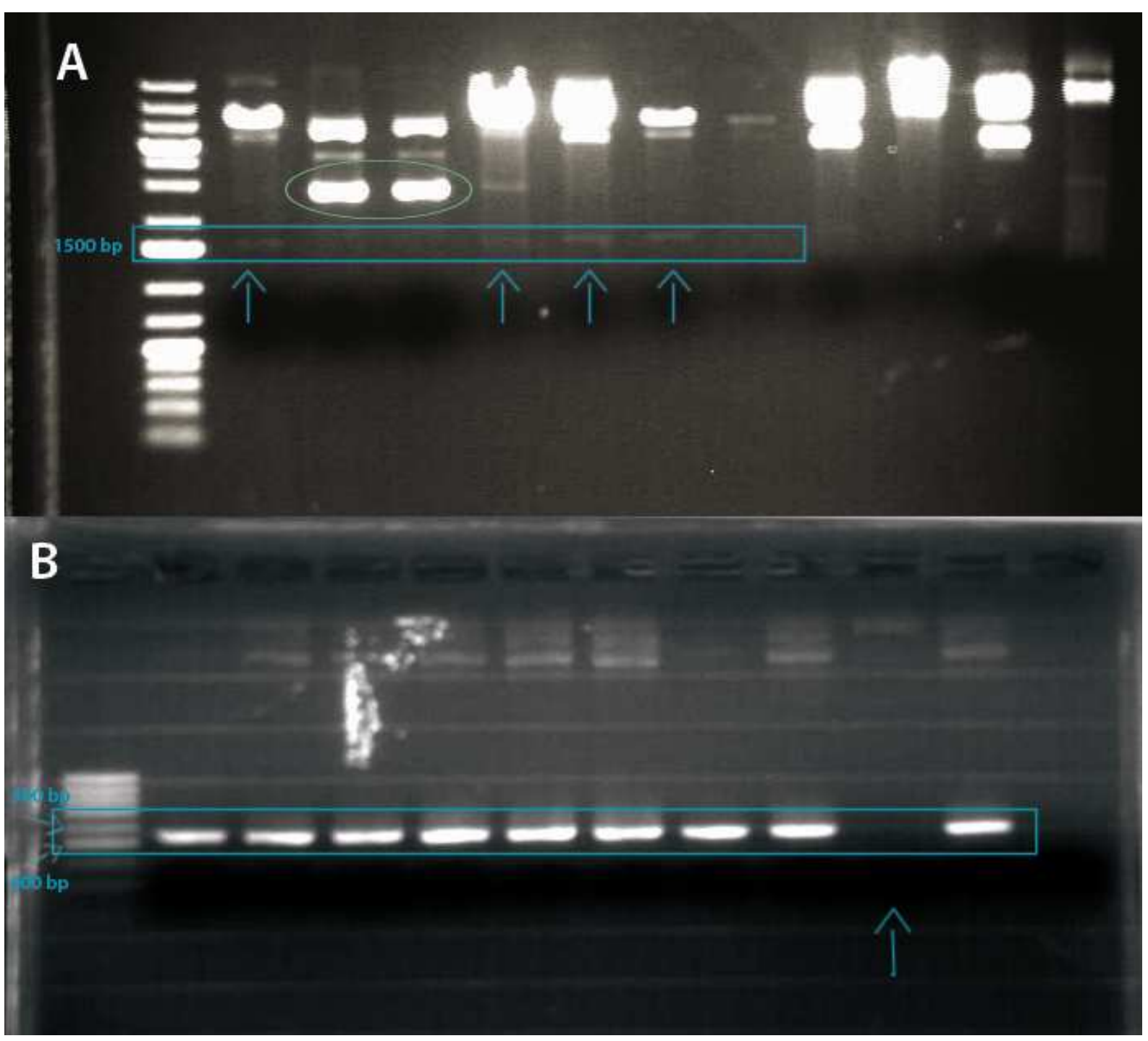
Figura 11 - Confirmação do processo de clonagem do inserto dc-lamp/gag. Géis de agarose para corrida eletroforética demonstrando o sucesso do processo de clonagem do inserto dc-lamp/gag no vetor pWPXLd. Gel A, o plasmídeo clonado foi submetido a digestão com a enzima de restrição EcoRI. A presença da banda de 1500 bp (setas) demonstra a correta inserção do fragmento. Bandas dentro do círculo (3000 bp) demonstram possivelmente ligação invertida. Gel B, a banda de 543 bp refere-se ao fragmento do gene gag amplificado por PCR, presente apenas nos plasmídeos clonados e no plasmídeo-controle pITR DC-LAMP/gag. Notar ausência de banda no poço com o plasmídeo-vetor pWPXLd apenas. bp, pares de bases.

Por outro lado, o plasmídeo pNL4-3 ${ }^{\mathrm{HSA}}$ pol-env-, que expressa ambas as seqüências de empacotamento, pôde ser utilizado diretamente com na construção do vetor. Então, cada um dos plasmídeos (pGSEF ou pNL4-3 ${ }^{\text {HSA }}$ pol-env-) foi cotransfectado com os plasmídeos pMD2.G (envelope) e psPAX2 (capsídeo) em células da linhagem HEK 293T e o sobrenadante dessas culturas foi coletado durante 96 horas. A titulação dos lentivírus foi realizada pela detecção da proteína p24 (capsídeo viral), utilizando anticorpo monoclonal específico para citometria de fluxo. Após três tentativas, foi obtido o máximo de $3,1 \times 10^{6} \mathrm{TU} / \mathrm{mL}$ do vetor pNL4-3 ${ }^{\mathrm{HSA}}$ pol-env- e 9,6 $\times 10^{6} \mathrm{TU} / \mathrm{mL}$ do vetor de pGSEF (cerca de $20 \mathrm{~mL}$ de cada vetor).

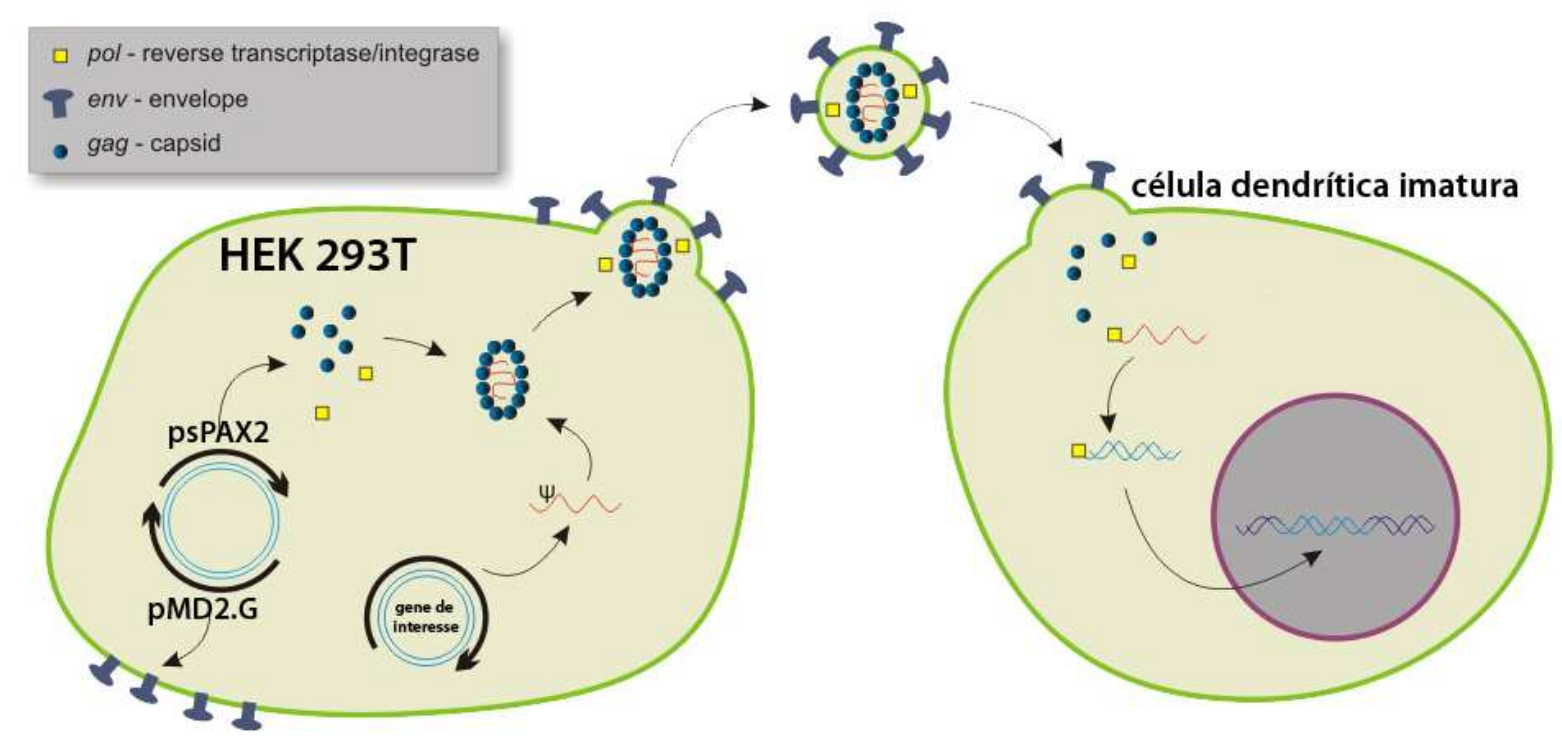

Figura 12 - Esquema de produção dos vetores lentivirais. Representação esquemática da produção dos vetores lentivirais em células da linhagem HEK 293T e transdução das células dendríticas (célula-alvo).

Em seguida, a capacidade de transdução do vetores nas células dendríticas imaturas foi avaliada segundo a expressão da proteína GFP (gene-repórter), também por citometria de fluxo. Entretanto, em nenhum dos experimentos realizados foi observado expressão dessa proteína em quantidades significativas 
(menos de 0,2\% de expressão). Apesar disso, a proteína p24 (capsídeo do lentivírus) foi detectada em cerca de $60,6 \%$ das DCs imaturas transduzidas com o vetor de pNL4-3 ${ }^{\mathrm{HSA}}$ pol-env- e cerca de $98,1 \%$ das células transduzidas com o vetor de pGSEF (figura 13).
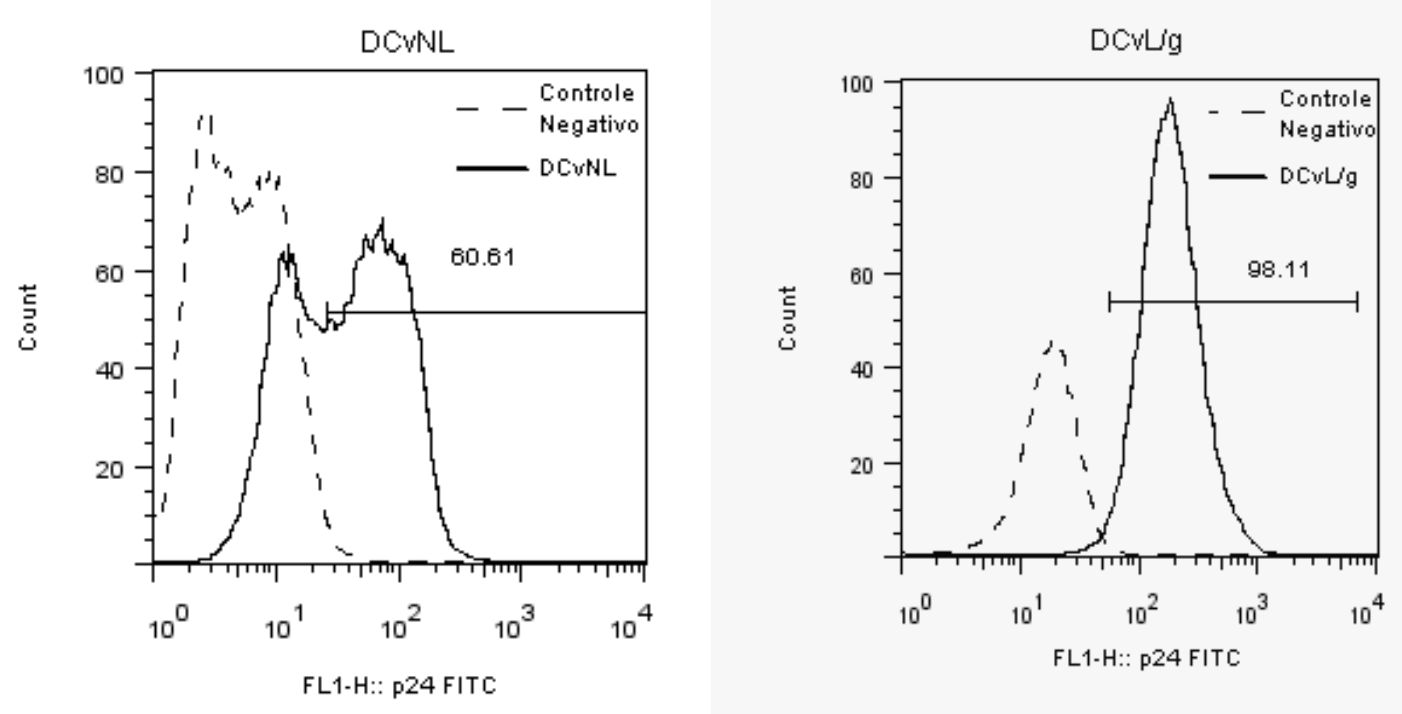

Figura 13 - Expressão da proteína p24 em células dendríticas imaturas. Células dendríticas (DCs) em seu estado imaturo, diferenciadas a partir de monócitos humanos, foram transduzidas com $5 \times 10^{5}$ unidades de transdução (TU) dos vetores lentivirais de pNL4-3 ${ }^{\text {HSA }}$ pol-env- (DCVNL) e de pGSEF (DCvL/g) por 2 horas a $37^{\circ} \mathrm{C}$ em placa de cultura. Quarenta e oito horas após processo de transdução, as DCs foram avaliadas quanto a expressão da proteína p24. Histogramas representativos de 3 experimentos independentes.

\subsection{Perfil Fenotípico das Células Dendríticas Diferenciadas de}

\section{Monócitos}

Células dendríticas imaturas (iDC) derivadas de monócitos obtidos a partir de sangue periférico de doadores sadios foram infectadas com pool de subtipos do HIV

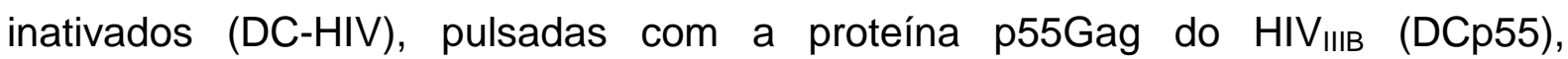
transduzidas com os vetores lentivirais de pNL4-3 ${ }^{H S A}$ pol-env- (DCVNL) e pGSEF $(\mathrm{DCvL} / \mathrm{g})$ ou simplesmente maturadas $(\mathrm{DCm})$, na presença de citocinas próinflamatórias (IL-1 $\beta$, IL-4, IL-6, TNFa e GM-CSF). O perfil fenotípico das DCs foi determinado por citometria de fluxo, utilizando-se anticorpos monoclonais específicos. O percentual de células expressando as moléculas CD14, HLA-DR, CD86, CD80, CD83 e CD1a foi determinado em células expressando simultaneamente a molécula CD11c, marcadora característica de células dendríticas mielóides. 
De um modo geral, observou-se que praticamente todas as células ainda no estado imaturo compõe uma população CD11C+CD14-, comprovando o sucesso do processo de diferenciação de monócitos em células dendríticas. Tal observação se mantém mesmo após o processo de maturação e ativação com citocinas e os diversos antígenos virais, demonstrando que as células utilizadas para estimulação dos linfócitos são realmente células dendríticas e não macrófagos ativados, os quais apresentam perfil semelhante de moléculas HLA e co-estimulatórias (CD86 e CD80), porém conservam a expressão de CD14. Esse perfil foi encontrado tanto em DCs diferenciadas a partir de monócitos de pares discordantes quanto de controles sadios não expostos, conforme apresentado nas figuras 14, 15, 16 e 17. 


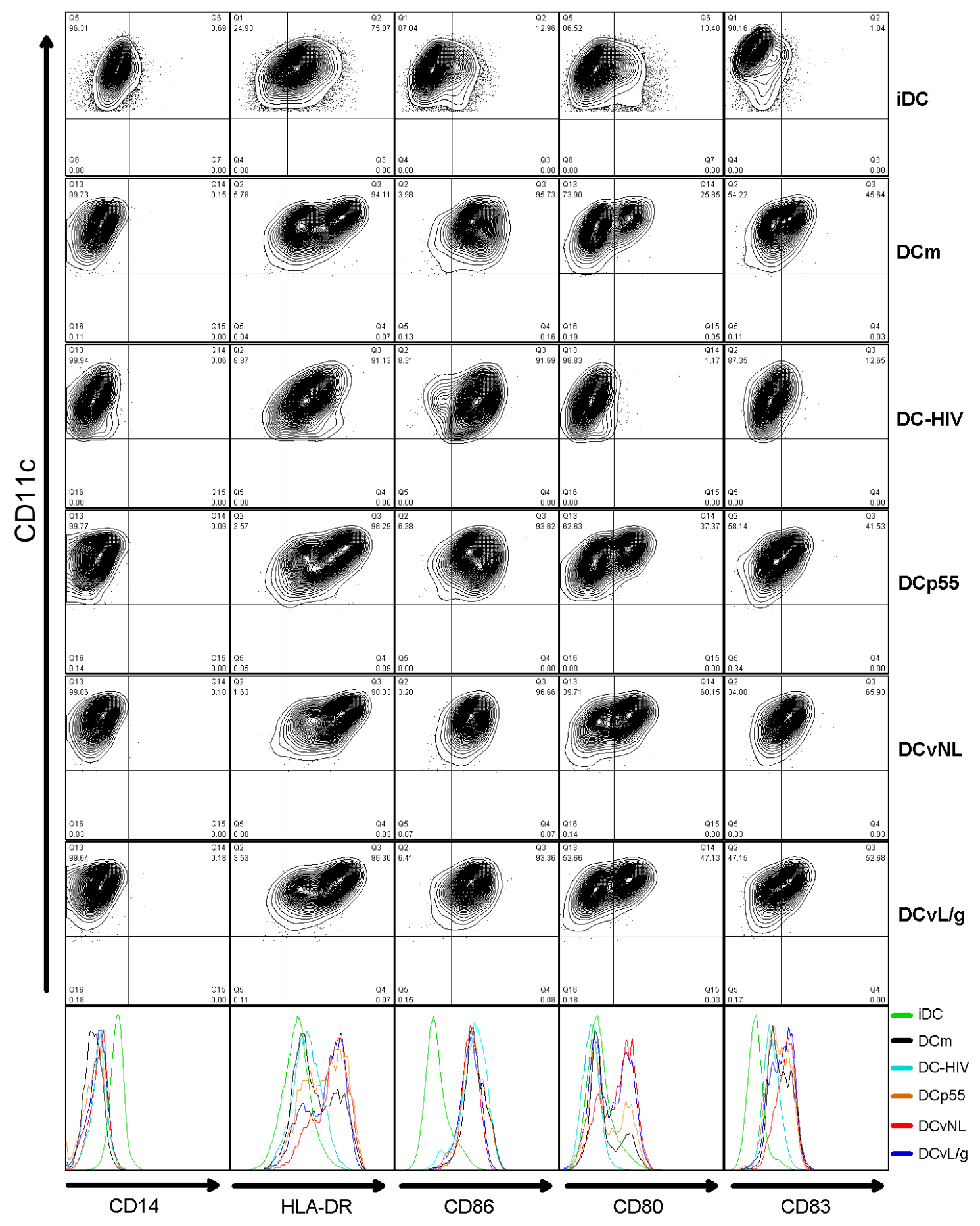

Figura 14 - Caracterização fenotípica das células dendríticas derivadas de monócitos de pares discordantes. Células dendríticas imaturas (DCs) de pares discordantes foram incubadas por 2 horas com um pool de subtipos inativados do HIV (DC HIV), a proteína p55 Gag (DCp55), os vetores lentivirais de pNL4-3HSApol-env- (DCvNL) e de pGSEF (DCvL/g) ou com meio de cultura apenas (DCm). Após 48 horas de maturação com coquetel de citocinas pró-inflamatórias, as células foram submetidas a ensaio de citometria de fluxo para avaliação das moléculas de superfície CD11c, CD14, HLA-DR, CD86, CD80 e CD83. Gráficos são representativos de um experimento num total de 7 realizados. 


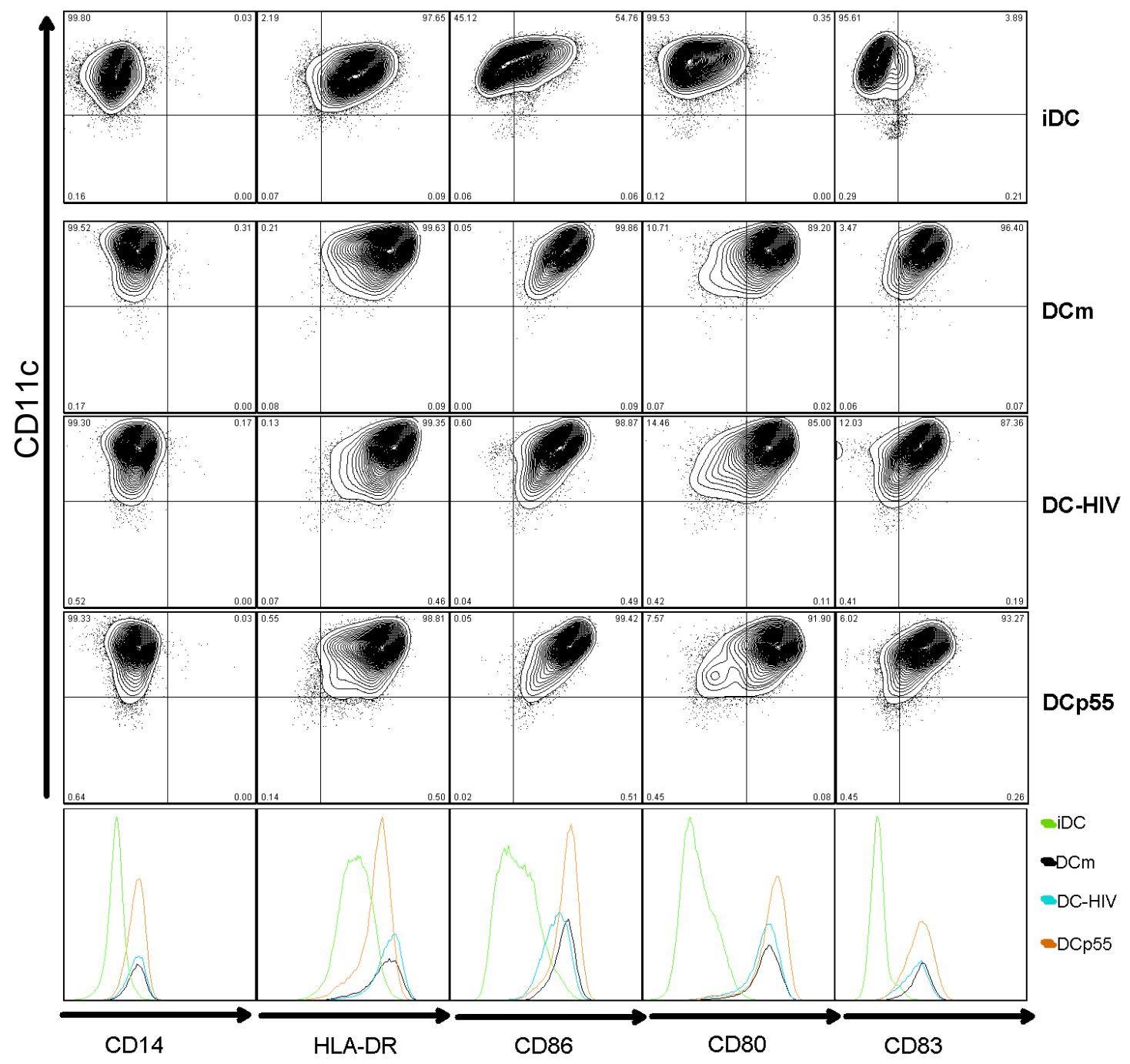

Figura 15 - Caracterização fenotípica das células dendríticas derivadas de indivíduos não expostos ao HIV. Células dendríticas imaturas (DCs) de indivíduos do grupo controle foram incubadas por 2 horas com um pool de subtipos inativados do HIV (DC HIV), a proteína p55 Gag (DCp55) ou com meio de cultura apenas (DCm). Após 48 horas de maturação com coquetel de citocinas pró-inflamatórias, as células foram submetidas a ensaio de citometria de fluxo para avaliação das moléculas de superfície CD11c, CD14, HLA-DR, CD86, CD80 e CD83. Gráficos são representativos de um experimento num total de 7 realizados.

O aumento encontrado na porcentagem da expressão das moléculas co-estimulatórias CD86 e CD80 evidenciado entre as células dendríticas imaturas e maduras, bem como o discreto aumento da expressão e intensidade média de fluorescência da molécula de apresentação antigênica HLA-DR na mesma comparação, sugerem mudança no padrão das células após processo de maturação. Tal mudança de padrão deve-se ao fato de que DCs imaturas são especializadas em fagocitose e processamento antigênico enquanto que, no estado maduro, elas perdem essa característica e tornam-se especialistas em apresentação de antígenos para linfócitos T. Além disso, ainda comparando-se seu estado de 
maturação, pôde-se observar significativa diferença na expressão da molécula CD83, utilizada como marcadora de ativação celular.

Com relação à molécula CD1a, nenhuma diferença estatisticamente significativa foi observada entre os parâmetros de células dendríticas analisados. Todavia, houve uma grande diferença da expressão dessa molécula entre os diversos indivíduos pesquisados (variação de $2,06 \%$ a $65,79 \%$ ).

Por fim, comparando-se as DCs imaturas e maduras de pares discordantes e de indivíduos do grupo controle, não foi encontrada nenhuma diferença em quaisquer das moléculas analisadas.

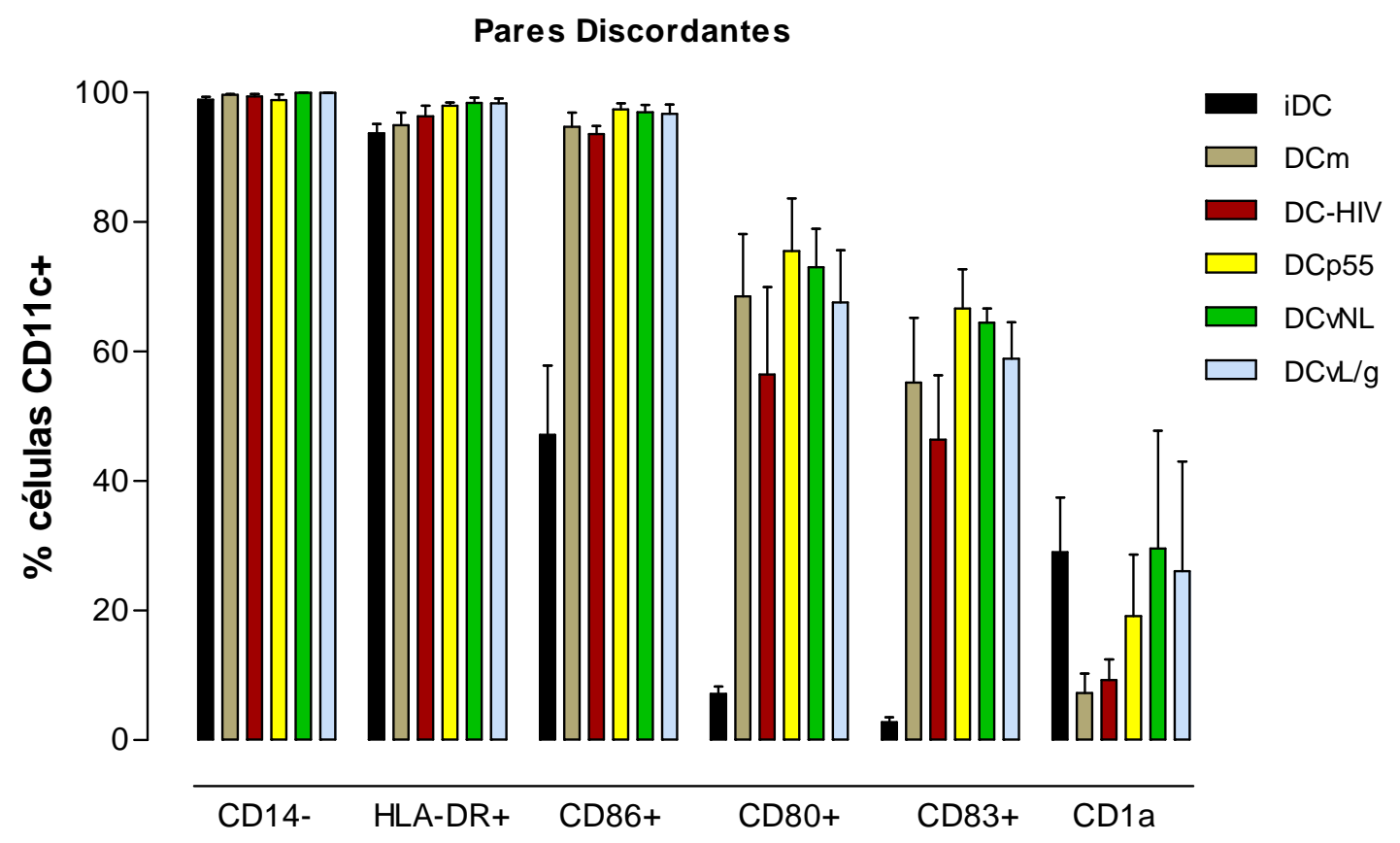

Figura 16 - Perfil fenotípico de células dendríticas de pares discordantes. Análise da expressão das moléculas de superfície CD11c, CD14, HLA-DR, CD86, CD80, CD83 e CD1a de células dendríticas (DCs) derivadas de monócitos de indivíduos sadios expostos ao HIV mas não infectados em diferentes condições: iDC, DCs imaturas; DCm, DCs maduras não pulsadas com antígenos; DCHIV, DCs maduras infectadas com pool de subtipos do HIV-1 inativados; DCp55, DCs maduras pulsadas com a proteína p55Gag do HIV-1 $1_{\text {IIIB, }}$ DCvNL, DCs maduras transduzidas pelo vetor lentiviral de pNL4-3 ${ }^{\mathrm{HSA}}$ pol-env-; DCvL/g, DCs maduras transduzidas pelo vetor lentiviral de pGSEF. 


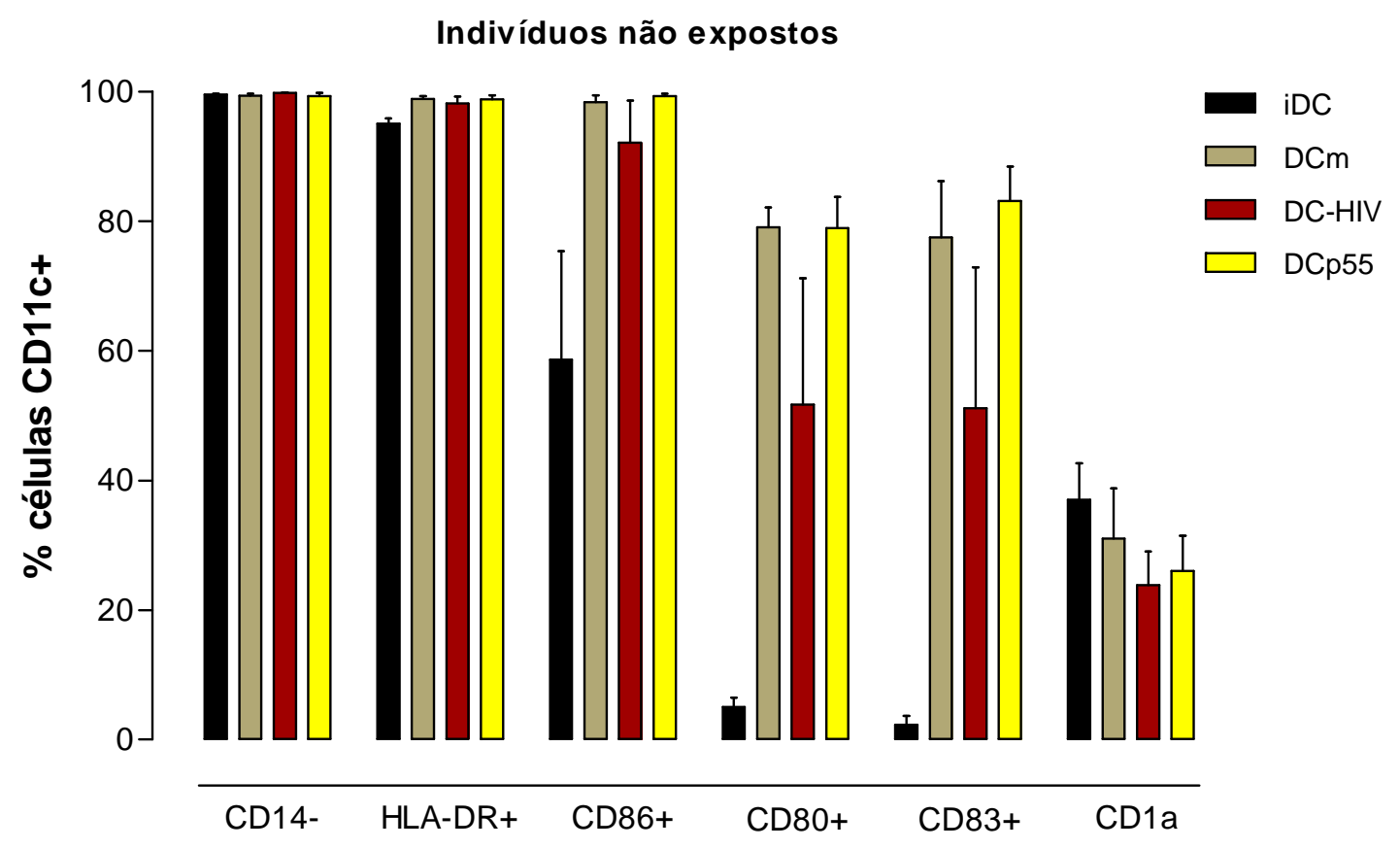

Figura 17 - Perfil fenotípico de células dendríticas de indivíduos não expostos ao HIV. Análise da expressão das moléculas de superfície CD11c, CD14, HLA-DR, CD86, CD80, CD83 e CD1a de células dendríticas (DCs) derivadas de monócitos de indivíduos sadios do grupo controle em diferentes condições: iDC, DCs imaturas; DCm, DCs maduras não pulsadas com antígenos; DCHIV, DCs maduras infectadas com pool de subtipos do HIV-1 inativados; DCp55, DCs maduras pulsadas com a proteína p55Gag do HIV-1 $1_{\text {IIIB }}$.

\subsection{Perfil de Secreção de Citocinas e Quimiocina das Células}

\section{Dendríticas Diferenciadas de Monócitos}

O perfil de secreção das citocinas IL-10 e IL-12p70 e da quimiocina MIP-1 $\alpha$ das células dendriticas derivadas de monócitos foi determinado por ELISA antes e após processo de maturação com os diversos produtos antigênicos virais e as citocinas pró-inflamatórias.

Os gráficos das figuras 18 e 19 apresentam os dados obtidos de secreção de IL-10 e MIP-1 $\alpha$ por DCs de pares discordantes e controles não expostos. Observamse níveis muito baixos de produção de IL-10 (sempre abaixo de $100 \mathrm{pg} / \mathrm{mL}$ ) tanto em DCs imaturas quanto nas várias condições de DCs maduras analisadas. Como a IL-10 é considerada uma das principais citocinas reguladoras do sistema imune, tais resultados sugerem que as células dendríticas utilizadas para estimulação dos linfócitos T não apresentam um perfil de supressão imunológica. Entretanto, não foi detectada secreção de IL-12p70, que é considerada a citocina padrão de resposta 
Th1 de APCs, em nenhuma das condições das DCs analisadas no sobrenadante de 18 horas de co-cultivo.

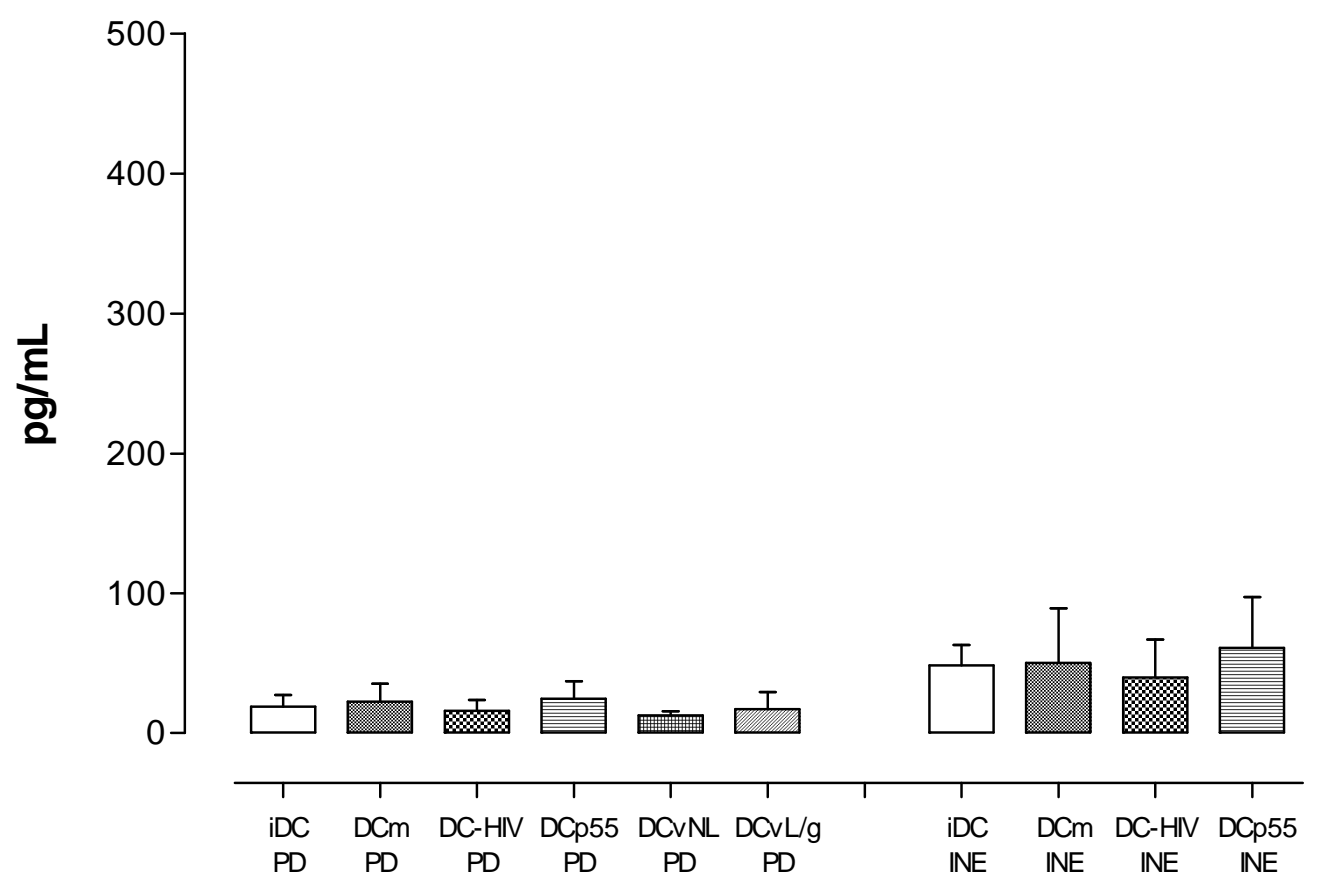

Figura 18 - Perfil de secreção de IL-10 de células dendríticas derivadas de monócitos. Análise da produção de IL-10 por células dendríticas (DCs) derivadas de monócitos de pares discordantes (PD) e indivíduos sadios não expostos ao HIV (INE) do grupo controle, em diferentes condições: iDC, DCs imaturas; DCm, DCs maduras não pulsadas com antígenos; DCHIV, DCs maduras infectadas com pool de subtipos do HIV-1 inativados; DCp55, DCs maduras pulsadas com a proteína p55Gag do HIV-1 $1_{\text {IIIB }}$ DCvNL, DCs maduras transduzidas pelo vetor lentiviral de pNL4-3 ${ }^{\mathrm{HSA}}$ pol-env-; DCvL/g, DCs maduras transduzidas pelo vetor lentiviral de pGSEF.

Com relação à produção de MIP- $1 \alpha$, pôde-se observar que as células dendríticas maduras, em todas as condições, produziram quantidades significativamente maiores da quimiocina do que as DCs imaturas tanto de pares discordantes (iDC, $276 \pm 150 \mathrm{pg} / \mathrm{mL} ; \quad \mathrm{DCm}, \quad 5860 \pm 890 \mathrm{pg} / \mathrm{mL} ; \quad$ DC-HIV, $5467 \pm 1004 \mathrm{pg} / \mathrm{mL} ; \quad \mathrm{DCp} 55, \quad 6774 \pm 1151 \mathrm{pg} / \mathrm{mL} ; \quad$ DCvNL,$\quad 11411 \pm 2796 \mathrm{pg} / \mathrm{mL}$; $\mathrm{DCvL} / \mathrm{g}, \quad 9726 \pm 3561 \mathrm{pg} / \mathrm{mL}$ ) quanto de indivíduos não expostos (iDC, $249 \pm 193 \mathrm{pg} / \mathrm{mL} ; \mathrm{DCm}, 4865 \pm 1739 \mathrm{pg} / \mathrm{mL} ;$ DC-HIV, $5147 \pm 1271 \mathrm{pg} / \mathrm{mL} ; \mathrm{DCp} 55$, $5951 \pm 2679 \mathrm{pg} / \mathrm{mL}$ ). Esses resultados estão de acordo com o conhecimento de que DCs imaturas são especializadas em fagocitose e processamento de antígenos enquanto que as DCs maduras apresentam perfil quase exclusivo de apresentação antigênica e de ativação do sistema imune, sendo que neste último processo a quimiotaxia apresenta papel fundamental. 


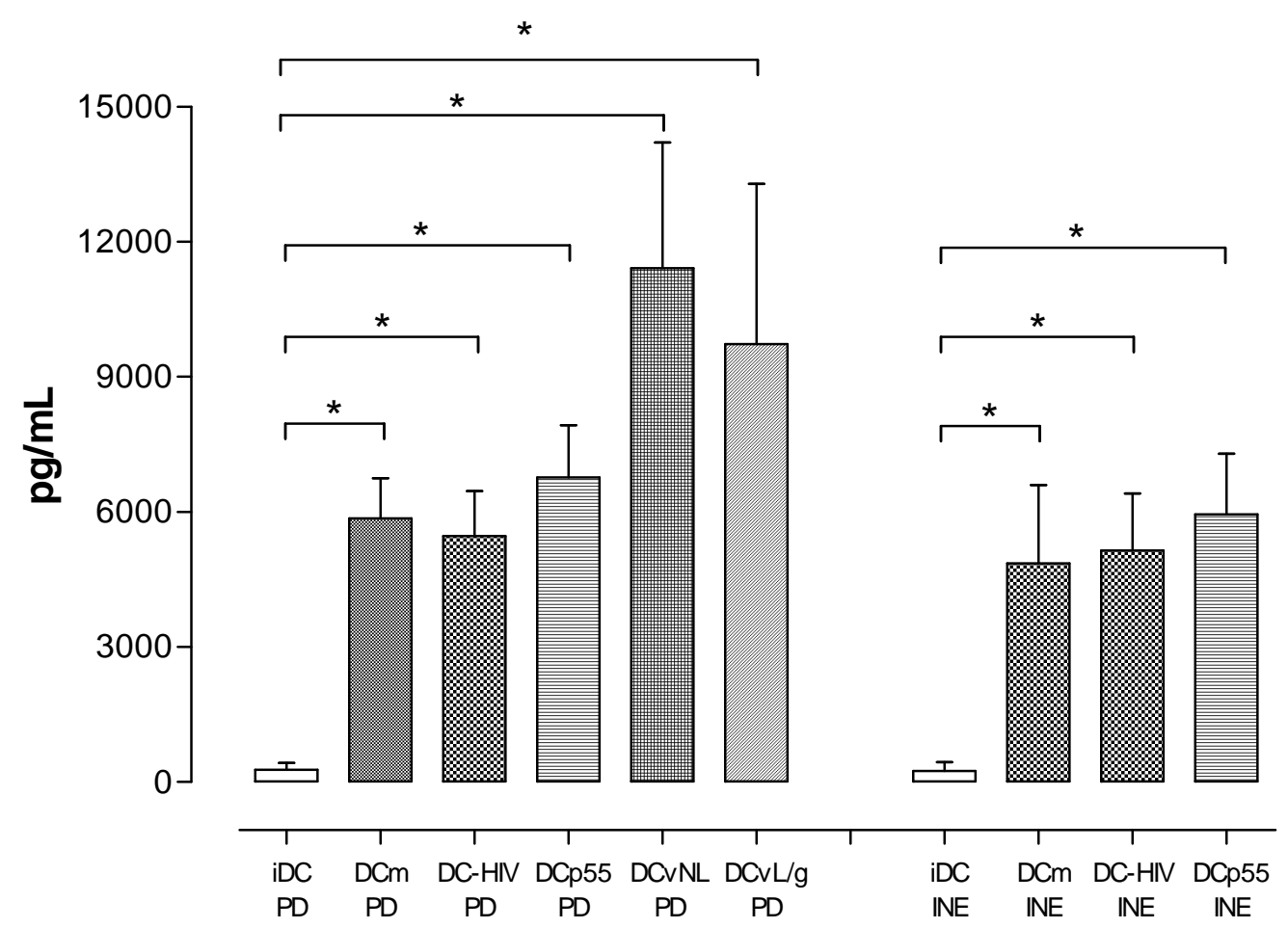

Figura 19 - Perfil de secreção de MIP-1 $\alpha$ de células dendríticas derivadas de monócitos. Análise da produção de MIP-1a por células dendríticas (DCs) derivadas de monócitos de pares discordantes (PD) e indivíduos sadios não expostos ao HIV (INE) do grupo controle, em diferentes condições: iDC, DCs imaturas; DCm, DCs maduras não pulsadas com antígenos; DCHIV, DCs maduras infectadas com pool de subtipos do HIV-1 inativados; DCp55, DCs maduras pulsadas com a proteína p55Gag do HIV-1 $1_{\text {IIIB }}$, DCvNL, DCs maduras transduzidas pelo vetor lentiviral de pNL4-3 ${ }^{\mathrm{HSA}}$ pol-env-; $\mathrm{DCvL} / \mathrm{g}, \mathrm{DCs}$ maduras transduzidas pelo vetor lentiviral de pGSEF. ${ }^{*}, \mathrm{p}<0,05$.

\subsection{Proliferação e Ativação Celular e Produção de Citocinas dos}

\section{Linfócitos T HIV-específicos Estimulados por Células Dendríticas}

\section{Autólogas}

Células dendríticas derivadas de monócitos foram infectadas ou não com pool de subtipos do HIV-1, pulsadas com a proteína p55Gag ou transduzidas com os vetores de pNL4-3 ${ }^{\text {HSA }}$ pol-env- e pGSEF e ativadas através de cultivo por 48 horas na presença de citocinas pró-inflamatórias. Após este período as células foram cocultivadas com linfócitos autólogos na proporção de $1: 5$ por 7 dias, quando receberam reforço de DCs frescas "carregadas" com os mesmos antígenos. Para o ensaio de proliferação celular, as células foram transportadas nesse dia para placas de 96 poços e timidina tritiada foi adicionada 18 horas antes do término da cultura. Para quantificação intracelular do IFN $\gamma$ e da expressão da molécula CD38 (ativação celular), as células foram mantidas em placas de 48 poços e brefeldina $A$ foi 
acrescentada à cultura 18 horas antes de seu encerramento. Por sua vez, o IFN $\gamma$ e a IL-10 secretados foram quantificados no sobrenadante do co-cultivo, de uma alíquota retirada imediatamente antes do acréscimo de brefeldina $A$.

Os resultados obtidos de linfoproliferação dos linfócitos HIV-específicos estimulados pelas várias condições de DCs estão representados na figura 20. Células dendríticas maduras infectadas com HIV inativado (DC-HIV) ou pulsadas com a proteína p55Gag (DCp55) estimularam significativamente mais a proliferação dos linfócitos T em co-cultivo dos pares discordantes em comparação com as DCs maduras que não apresentavam antígenos virais $(10167 \pm 3548 \mathrm{cpm}$, $16090 \pm 5992 \mathrm{cpm}, \quad 3295 \pm 1583 \mathrm{cpm}$; respectivamente). Entretanto, os mesmos resultados foram encontrados no grupo controle, isto é, os linfócitos $T$ dos indivíduos não expostos ao HIV proliferaram significativamente mais frente à estimulação por DC-HIV e DCp55 em comparação com a proliferação em resposta a DCm apenas $(21501 \pm 5086 \mathrm{cpm}, 25929 \pm 5896 \mathrm{cpm}, 6335 \pm 4288 \mathrm{cpm})$. Ainda, as DCs transduzidas com os vetores lentivirais de pNL4-3 ${ }^{H S A}$ pol-env- (DCvNL) e pGSEF (DCvL/g) não foram capazes de estimular a proliferação dos linfócitos $T$ dos pares discordantes (1965 \pm 366 cpm e $1482 \pm 402 \mathrm{cpm}$, respectivamente).

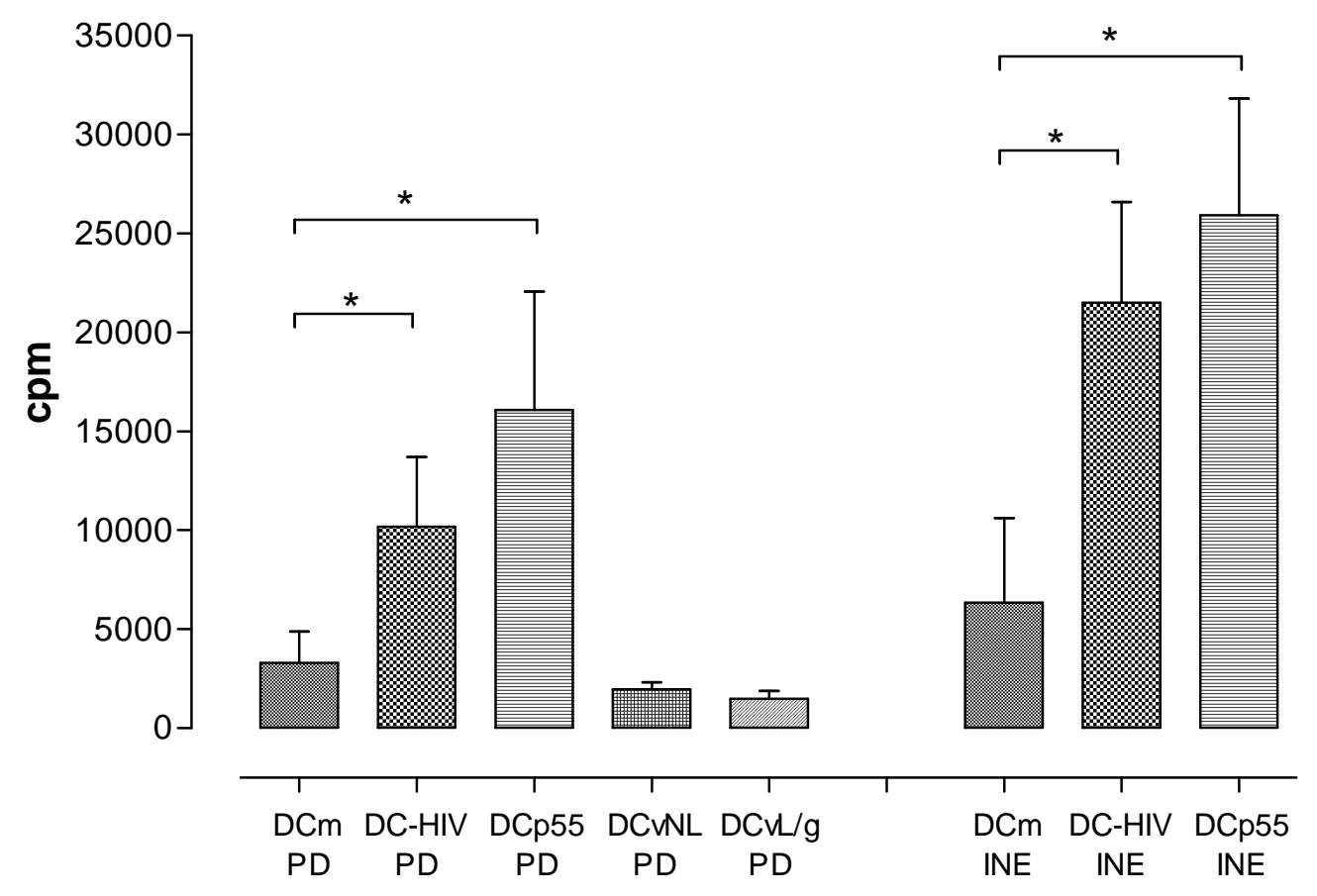

Figura 20 - Resposta linfoproliferativa de linfócitos estimulados por células dendríticas pulsadas com antígenos do HIV. Linfócitos de pares discordantes (PD) e de indivíduos não expostos (INE) do grupo controle foram cultivados por 7 dias com células dendríticas autólogas ativadas (DCm), infectadas com pool de subtipos do 
HIV inativados (DC-HIV), pulsadas com a proteína p55Gag do HIV transduzidas pelos vetores lentivirais de pNL4-3 ${ }^{\mathrm{HSA}}$ pol-env- (DCvNL) e de pGSEF (DCvL/g) e, então, re-estimuladas com novas células dendríticas pulsadas com mesmo parâmetro utilizado no estímulo primário. A proliferação celular foi detectada 72 horas após estímulo secundário pela técnica de incorporação de timidina tritiada. cpm, contagem por minuto; ${ }^{*}, p<0,05$.

Da mesma forma, esse mesmo perfil de resposta foi observado em relação à ativação dos linfócitos $T$ em co-cultivo com as células dendríticas, segundo a expressão da glicoproteína CD38. Os linfócitos T CD4 de pares discordantes e de indivíduos não expostos expressam significativamente maior porcentagem da molécula CD38 em sua superfície quando estimulados por DC-HIV e DCp55, em comparação ao estímulo por DCm (PD: 11,6 \pm 5,2\%; 12,3 $\pm 5,0 \% ; 3,4 \pm 1,1 \%$; e INE: $12,9 \pm 4,2 \% ; 11,1 \pm 3,6 \% ; 2,6 \pm 0,5 \%$; respectivamente), assim como o fazem os linfócitos T CD8 dos mesmos indivíduos na mesma comparação, embora em percentuais menores (PD: $1,6 \pm 0,6 \%$; $2,3 \pm 1,1 \% ; 0,6 \pm 0,2 \%$; e INE: $1,2 \pm 0,2 \%$; $1,4 \pm 0,3 \% ; 0,4 \pm 0,07 \%$; respectivamente). Ainda, DCvNL e $D C v L / g$ não foram capazes de ativar os linfócitos T CD4 e CD8 dos pares discordantes $(3,5 \pm 1,9 \%$ e $3,7 \pm 2,2 \% ; 0,3 \pm 0,1 \%$ e $0,4 \pm 0,1 \%$, respectivamente).

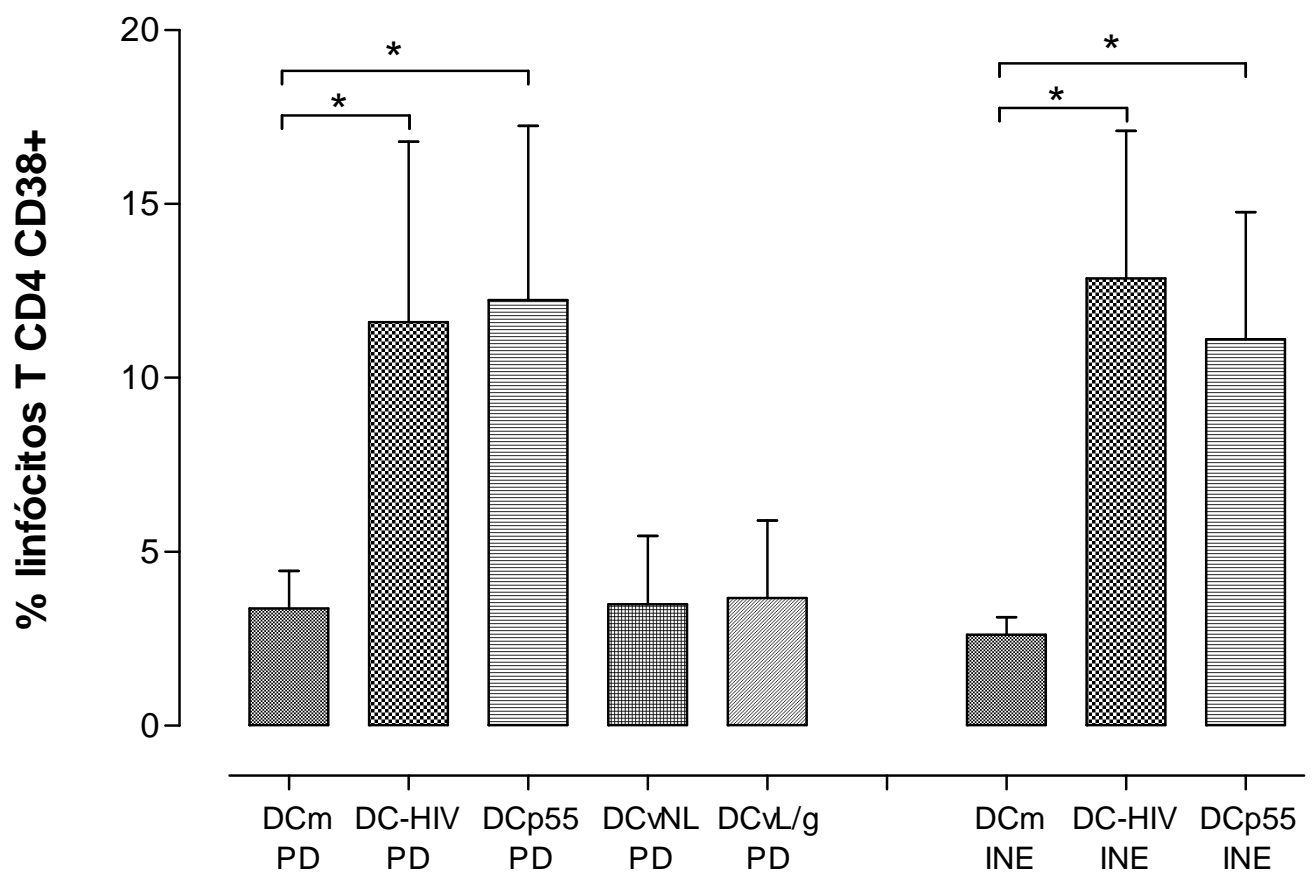




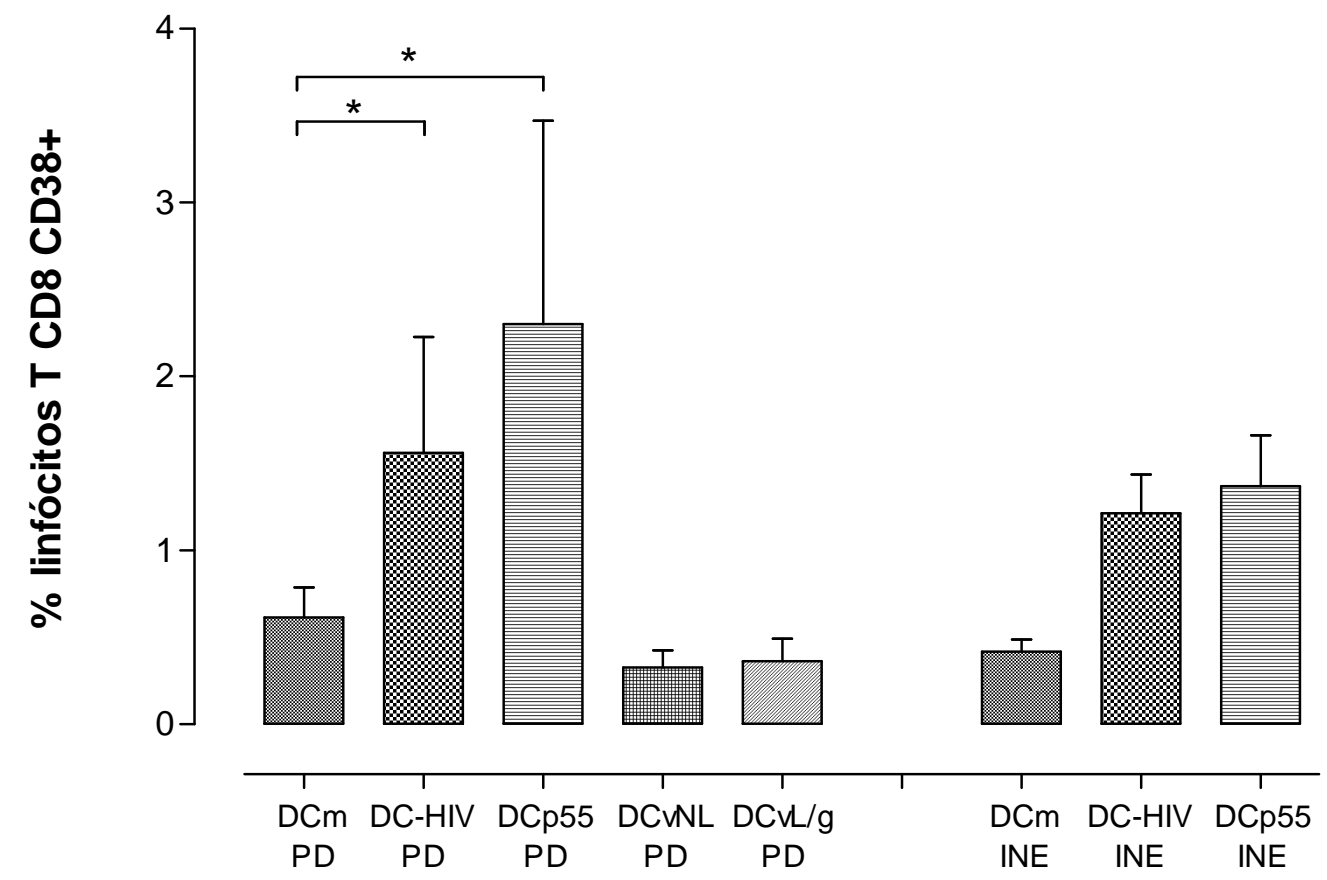

Figura 21 - Perfil de ativação de linfócitos T estimulados por células dendríticas pulsadas com antígenos do HIV. Linfócitos $T$ de pares discordantes (PD) e de indivíduos não expostos (INE) do grupo controle foram cultivados por 7 dias com células dendríticas autólogas ativadas (DCm), infectadas com pool de subtipos do HIV inativados (DC-HIV), pulsadas com a proteína p55Gag do HIV IIIB (DCp55) ou transduzidas pelos vetores lentivirais de pNL4-3 ${ }^{\mathrm{HSA}}$ pol-env- (DCvNL) e de pGSEF (DCvL/g) e, então, re-estimuladas com novas células dendríticas pulsadas com mesmo parâmetro utilizado no estímulo primário. A ativação celular foi avaliada segundo expressão da molécula CD38 em linfócitos T CD4 (gráfico superior) e CD8 (gráfico inferior) analisada por citometria de fluxo, 72 horas após estímulo secundário. *, $\mathrm{p}<0,05$.

Em contrapartida, a quantificação da produção de IFN $\gamma$ demonstrou ser uma técnica confiável para avaliar apenas os linfócitos T HIV-específicos, já que apenas as células dos indivíduos pares discordantes produziram essa citocina em resposta ao reconhecimento de epítopos do HIV apresentado pelas células dendríticas. A figura 22 apresenta os resultados obtidos de detecção intracelular de IFN $\gamma$ em linfócitos T CD4 e CD8, enquanto que a figura 23 apresenta os resultados da dosagem da proteína secretada no sobrenadante do co-cultivo de linfócitos e DCs.

Linfócitos T CD4 dos pares discordantes produziram significativamente mais IFN $\gamma$ quando estimulados por DC-HIV ou DCp55 em comparação ao estímulo por $\mathrm{DCm}$ apenas $(0,35 \pm 0,08 \% ; 0,30 \pm 0,10 \% ; 0,14 \pm 0,02 \%$; respectivamente) e em comparação à mesma estimulação de DCs dos indivíduos não expostos do grupo controle $(0,10 \pm 0,005 \% ; 0,10 \pm 0,02 \%$; respectivamente). Com relação aos linfócitos $\mathrm{T}$ CD8, houve maior produção de IFN $\gamma$ somente pelas células estimuladas por 
DC-HIV em comparação a condição basal DCm $(0,18 \pm 0,06 \%$ e $0,08 \pm 0,02 \%$; respectivamente) e em relação ao estimulo de DC-HIV dos controles $(0,03 \pm 0,01 \%)$.
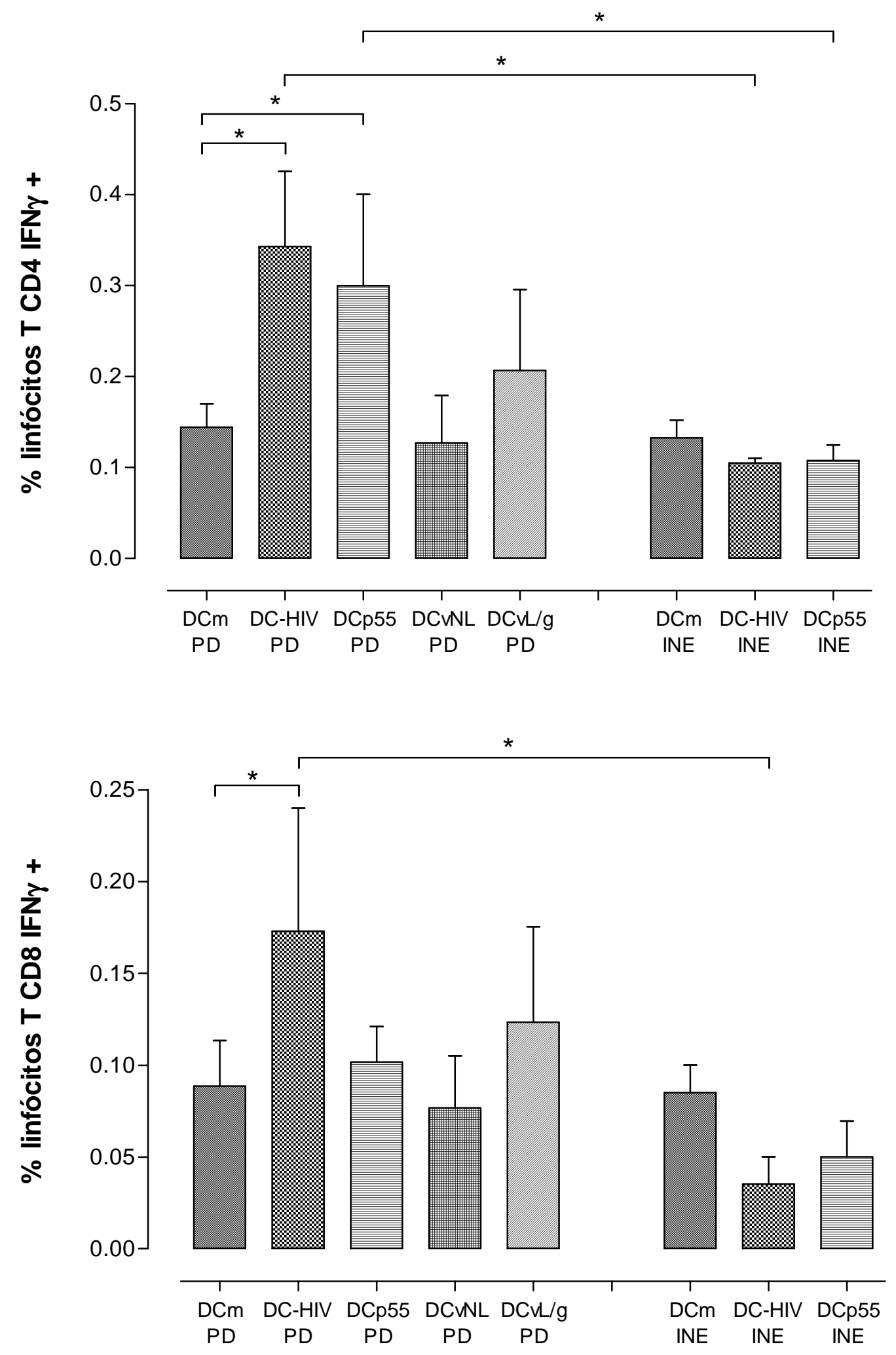

Figura 22 - Perfil de produção de IFN $\gamma$ de linfócitos T estimulados por células dendríticas pulsadas com antígenos do HIV. Linfócitos T de pares discordantes (PD) e de 
indivíduos não expostos (INE) do grupo controle foram cultivados por 7 dias com células dendríticas autólogas ativadas (DCm), infectadas com pool de subtipos do HIV inativados (DC-HIV), pulsadas com a proteína p55Gag do HIV IIIB $_{\text {(DCp55) ou }}$ transduzidas pelos vetores lentivirais de pNL4-3 ${ }^{\mathrm{HSA}}$ pol-env- (DCVNL) e de pGSEF (DCvL/g) e, então, re-estimuladas com novas células dendríticas pulsadas com mesmo parâmetro utilizado no estímulo primário. A produção de IFN $\gamma$ foi avaliada segundo detecção intracelular por citometria de fluxo em linfócitos T CD4 (gráfico superior) e CD8 (gráfico inferior), 72 horas após estímulo secundário. *, $\mathrm{p}<0,05$.

Da mesma forma, a dosagem da proteína no sobrenadante do co-cultivo mostrou uma maior produção de IFN $\gamma$ pelas células estimuladas por DCs apresentando antígenos virais (DC-HIV, $602 \pm 311 \mathrm{pg} / \mathrm{mL}$; DCp55, $903 \pm 334 \mathrm{pg} / \mathrm{mL}$ ) do que pela condição basal $\mathrm{DCm}(124 \pm 44 \mathrm{pg} / \mathrm{mL})$ e seus respectivos controles de indivíduos não expostos (DC-HIV, $201 \pm 127$ pg/mL; DCp55: $243 \pm 116$ pg/mL).

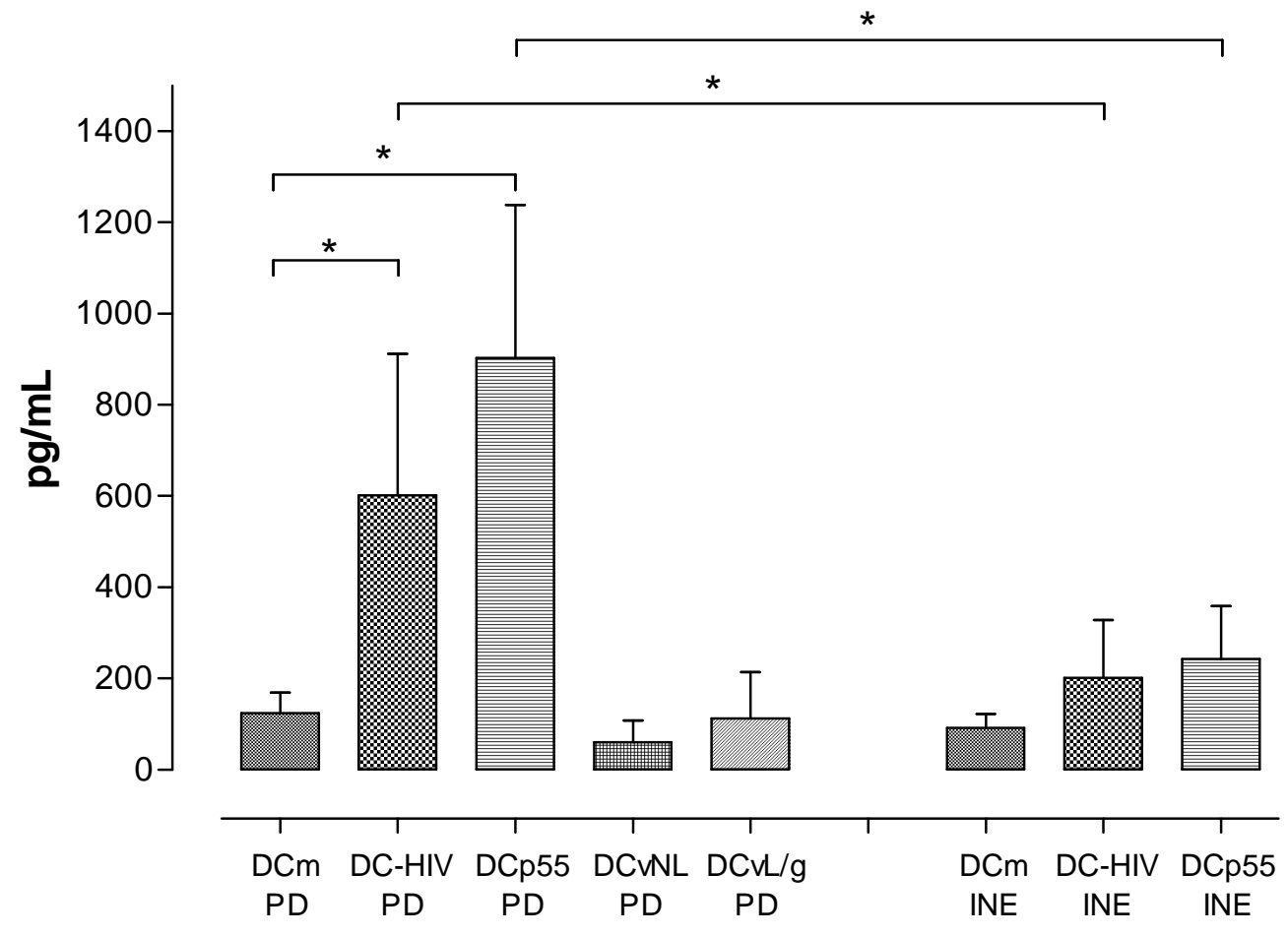

Figura 23 - Perfil de secreção de IFN $\gamma$ dos linfócitos estimulados por células dendríticas pulsadas com antígenos do HIV. Linfócitos de pares discordantes (PD) e de indivíduos não expostos (INE) do grupo controle foram cultivados por 7 dias com células dendríticas autólogas ativadas (DCm), infectadas com pool de subtipos do HIV inativados (DC-HIV), pulsadas com a proteína p55Gag do HIV ${ }_{\text {IIIB }}$ (DCp55) ou transduzidas pelos vetores lentivirais de pNL4-3 ${ }^{H S A}$ pol-env- (DCVNL) e de pGSEF $(\mathrm{DCvL} / \mathrm{g})$ e, então, re-estimuladas com novas células dendríticas pulsadas com mesmo parâmetro utilizado no estímulo primário. A secreção de IFN $\gamma$ foi quantificada em sobrenadante de co-cultivo com DCs pela técnica de ELISA, 72 horas após estímulo secundário. ${ }^{*}, p<0,05$. 
Por sua vez, praticamente nenhuma produção de IL-10 pelos linfócitos estimulados por células dendríticas foi detectada em sobrenadante de cultura (média de secreção sempre abaixo dos 100 pg/mL, em todas as condições.

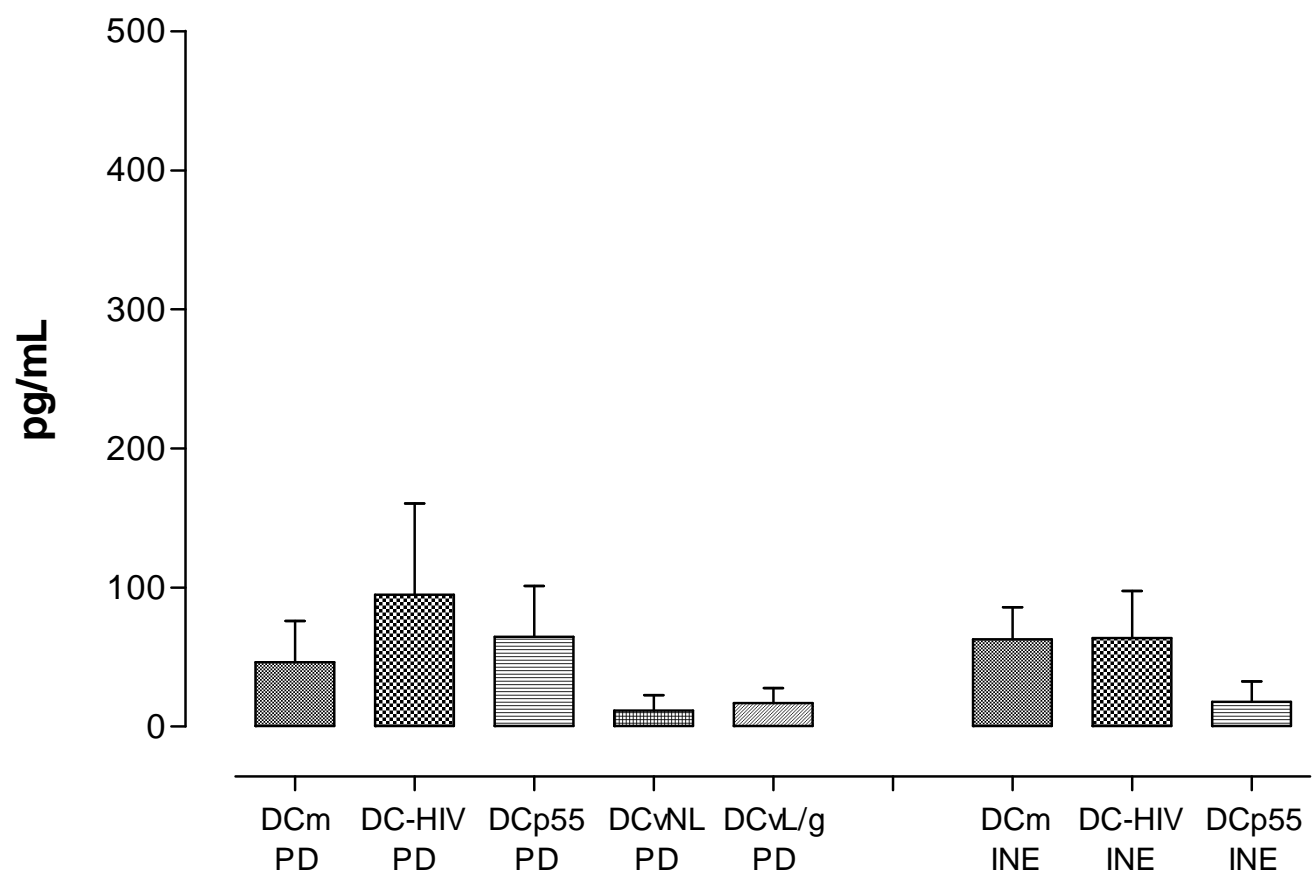

Figura 24 - Perfil de secreção de IL-10 dos linfócitos estimulados por células dendríticas pulsadas com antígenos do HIV. Linfócitos de pares discordantes (PD) e de indivíduos não expostos (INE) do grupo controle foram cultivados por 7 dias com células dendríticas autólogas ativadas (DCm), infectadas com pool de subtipos do HIV inativados (DC-HIV), pulsadas com a proteína p55Gag do HIV IIIB $_{\text {(DCp55) ou }}$ transduzidas pelos vetores lentivirais de pNL4-3 ${ }^{\text {HSA }}$ pol-env- (DCVNL) e de pGSEF (DCvL/g) e, então, re-estimuladas com novas células dendríticas pulsadas com mesmo parâmetro utilizado no estímulo primário. A secreção de IL-10 foi quantificada em sobrenadante de co-cultivo com DCs pela técnica de ELISA, 72 horas após estímulo secundário. 


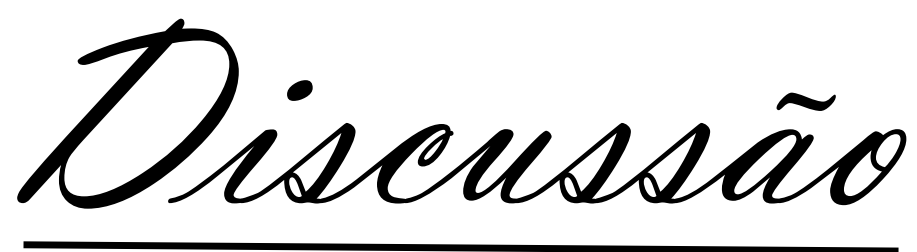




\section{DISCUSSÃo}

Com base em estudo pioneiro que utilizou células dendríticas derivadas de monócitos pulsadas com vírus autólogo inativado para o tratamento de indivíduos cronicamente infectados pelo HIV, no qual foram obtidos resultados parcialmente satisfatórios (supressão sustentada da carga viral após um ano de tratamento em apenas metade dos indivíduos vacinados), o presente estudo propôs-se a investigar a utilização in vitro de diferentes produtos antigênicos do HIV com objetivo de aperfeiçoar a apresentação antigênica por DCs e a resposta protetora num maior número de indivíduos. Quatro produtos distintos foram testados: pool de subtipos do vírus quimicamente inativados, proteína p55Gag, plasmídeo pNL4-3 ${ }^{\mathrm{HSA}}$ pol-env(genoma completo do HIV) e plasmídeos pITR DC-LAMP/gag (gene quimérico da proteína p55Gag e proteína associada ao lissosomo).

Inicialmente, fora proposto no projeto a utilização de derivados de bolsas de sangue denominados buffy coat para realização dos experimentos de obtenção de células dendríticas a partir de monócitos, infecção e/ou transfecção das mesmas e quantificação da resposta imune de linfócitos T estimulados em co-cultivo por essas APCs. Pela possibilidade de obtenção de um grande número de células mononucleares a partir de um único buffy coat, essa proposta parecia ser racional e adequada pois atendia, com sobra, a demanda exigida pelos muitos ensaios realizados. No entanto, em nenhum de três buffy coats utilizados foi possível detectar produção de IFN $\gamma$ dos linfócitos $T$ estimulados pelas células dendríticas infectadas com o pool de subtipos do HIV, apesar de comprovada a completa diferenciação dos monócitos em DCs e a maturação e ativação das mesmas. Tal fato deve-se provavelmente à ínfima quantidade de clones de linfócitos HIV específicos encontrada em pessoas sadias que teoricamente nunca foram expostas ao vírus.

Frente ao insucesso dessa etapa e, uma vez que para estes ensaios é necessário grande volume de sangue, cuja obtenção é inviável em se tratando de pacientes com aids, amostras de sangue de indivíduos sadios altamente expostos ao HIV, porém não infectados foram utilizadas. A opção por estes grupos se deve ao fato de que estes indivíduos são capazes de desenvolver resposta específica ao 
HIV, a despeito de não apresentarem infecção pelo vírus (SUY et al., 2007). Assim sendo, como a quantidade de clones específicos ao HIV é maior nestes indivíduos, comparados aos indivíduos não expostos, maior é a probabilidade de se obter reposta específica aos produtos antigênicos do HIV que este estudo propôs avaliar. Contudo, antes de serem incluídos no trabalho, indivíduos com este perfil foram selecionados através da avaliação de sua capacidade em responder a antígenos específicos do HIV por ensaio de proliferação celular e secreção de IFN $\gamma$.

Dos 20 indivíduos selecionados, apenas 10 apresentaram resposta imune contra antígenos virais específicos. É possível que a metade dos pares discordantes não respondedores aos testes não tenham tido uma exposição prévia tão intensa, ou sequer alguma exposição, aos vírus de seus parceiros quanto a exposição daqueles classificados como respondedores segundo os critérios estipulados, apesar de todos terem informado a prática de repetidas relações sexuais desprotegidas em algum momento de suas vidas. Além disso, os antígenos utilizados para realização desses ensaios também podem ter influenciado os resultados obtidos. Por comodidade, pois dispúnhamos de grandes quantidades, foram empregados vírus HIV inativados. Porém, partículas virais inteiras não são tão facilmente fagocitadas e processadas pelas APCs como proteínas pequenas. Provavelmente, um sonicado ou lisado dos vírus inativados propiciaria a fagocitose das diversas proteínas virais, aumentando o potencial imunogênico desse antígeno. Por outro lado, foi obtida apenas uma pequena quantidade da proteína p55Gag e, por essa razão, não foi possível a realização de uma curva para determinar a concentração ótima que deveria ser utilizada desse antígeno na cultura celular. Talvez, diferentes concentrações da utilizada poderiam estimular a proliferação dos

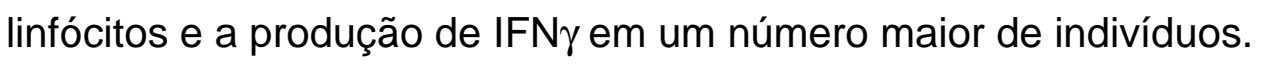

Uma vez realizada a triagem inicial, os indivíduos selecionados foram reconvocados e seguiram-se os experimentos de obtenção de células dendríticas a partir de monócitos. Tal etapa foi realizada com sucesso, conforme evidenciado pelos resultados obtidos pela análise da expressão das moléculas de superfície celular. Após 6 dias em cultura com as citocinas IL-4 e GM-CSF, quase que a totalidade (cerca de $98-100 \%$ ) dos monócitos perderam a expressão da proteína co-receptora de LPS, CD14, e passaram a expressar a integrina CD11c, que é utilizada como marcadora de célula dendrítica mielóide. Todavia, DCs recém- 
diferenciadas apresentam-se como células imaturas. Sabe-se que nesse estágio de desenvolvimento, as DCs exibem perfil predominante de células fagocíticas e não são capazes de estimular linfócitos $\mathrm{T}$; ao contrário, já foram descritas como indutoras de tolerância (DHODAPKAR, 2001; DHODAPKAR e STEINMAN, 2002; HAWIGER et al., 2001, JIN et al., 2004; LUTZ e SCHULER, 2002; STEINBRINK et al., 1997; WILSON et al., 2004). Por esse motivo, as células foram submetidas ao processo de maturação com um coquetel de citocinas pró-inflamatórias composto de IL-1 $\beta$, IL-6 e TNF $\alpha$. Novamente, analisando as proteínas da membrana celular, pôde-se observar claramente uma mudança no padrão de expressão dessas moléculas, em conformidade ao já amplamente descrito na literatura. DCs maduras apresentaram expressão muito maior das moléculas co-estimulatórias CD80 e CD86, da glicoproteina CD83, considerada um marcador da maturação de células dendríticas (BERCHTOLD et al., 1999; ZHOU et al., 1996), e níveis superiores de expressão por célula da molécula de apresentação antigênica HLA-DR (maior IMF), além de produção muito maior da quimiocina MIP-1 $\alpha$, em comparação a células dendríticas imaturas. Em conjunto com os resultados de baixa secreção de IL-10, esses dados sugerem uma mudança do perfil fagocítico de DCs imaturas para células especializadas na apresentação de antígenos propícias a estimulação dos linfócitos T, apesar de não ter sido detectada nenhuma secreção de IL-12, citocinapadrão de resposta Th1. Cabe ressaltar ainda que exatamente os mesmo resultados foram obtidos nos processos de diferenciação e maturação das DCs do grupo controle, confirmando mais uma vez o sucesso dessa etapa.

Por outro lado, o "carregamento antigênico" dessas células não ocorreu de forma tão simples como inicialmente planejado. O processo de infecção das DCs imaturas pelos subtipos virais é relativamente fácil, uma vez que, mesmo inativados os vírus mantém a capacidade de infectar células, pois mantém intacta a estrutura de suas proteínas de envelope gp120 e gp41. Por sua vez, as DCs imaturas são plenamente capazes de endocitar proteínas presentes no sobrenadante da cultura, como a p55Gag pulsada. Entretanto, alguns testes iniciais demonstraram que, in vitro, essas células não foram capazes de interiorizar o plasmídeo testado, como ocorre em algumas situações in vivo (CONDON et al., 1996; HATTORI et al., 2006). Para tal processo, foi necessária a utilização de vetores capazes de transpor a membrana plasmática das DCs. Lipídeos catiônicos aparentavam ser a escolha 
ideal, pois, além de baratos e metodologicamente simples, resultavam em níveis altos de expressão das proteínas transfectadas em células de linhagem (FELGNER et al., 1987; ZHDANOV et al., 2002). Mais uma vez, no entanto, testes realizados com esses reagentes falharam na tentativa de transfectar in vitro células primárias como linfócitos e células dendríticas, corroborando os resultados de Landi, et al. (2007) em estudo testando diversos reagentes e metodologias de transfecção de DCs humanas.

A alternativa metodológica proposta para a solução desse problema foi a utilização de vetores virais, os quais já vêm sendo amplamente utilizados em diversos estudos relacionados ao câncer (BRECKPOT et al., 2003; LUO et al., 2008), terapia gênica com células-tronco (BARTH et al., 2008) e silenciamento genômico (YANG et al., 2008), além do desenvolvimento de vacinas (HE et al., 2005; WINGARD et al., 2008). Entretanto, vetores retrovirais não são capazes de infectar e transduzir células que não se dividem, tornando seu uso inviável nesse projeto. Assim como, a utilização de adenovírus com esse propósito já se mostrou até mesmo prejudicial devido a rápida resposta imune desenvolvida contra o vetor, uma vez que infecções oculares e dos tratos respiratório e gastrointestinal em humanos são comumente causados por vírus dessa família. Dessa forma, a alternativa adequada para o projeto foi a utilização de um vetor lentiviral baseado em HIV pseudotipado, o qual é capaz de transduzir células que não se dividem como as células dendríticas e integrar o gene ao genoma celular, permitindo sua expressão. Vetores virais com o pNL4-3 ${ }^{\mathrm{HSA}}$ pol-env- foram construídos diretamente com os plasmídeos que codificavam o envelope e o capsídeo do lentivírus, enquanto que o gene $d c$-lamp/gag teve de ser clonado em um plasmídeo específico, que expressava os sinais necessários ao correto empacotamento do gene no capsídeo lentiviral.

Todavia, os resultados obtidos em experimentos de transdução celular sugerem uma possível falha técnica com relação a integração do gene de interesse no genoma da célula dendrítica, uma vez que foram detectados elevados níveis da proteína p24 (capsídeo) na membrana das células transduzidas, indicando a capacidade de infecção do vetor, porém não foi observada expressão da proteínarepórter (GFP) que deveria ser traduzida juntamente com o gene integrado. Apesar das verificações, é possível que a clonagem do gene $d c$-lamp/gag não tenha sido realizada corretamente, inserindo seqüências nucleotídicas que impossibilitaram a 
construção do vetor ou sua integração no genoma. No caso do plasmídeo pNL4-3 ${ }^{\text {HSA }}$ pol-env-, talvez seu tamanho (aproximadamente $15 \mathrm{~Kb}$ ) possa ter atrapalhado o correto empacotamento no vetor. Mais experimentos deverão ser realizados, inclusive o seqüenciamento completo do plasmídeo pGSEF (clonagem do gene dc-lamp/gag), para conclusão definitiva sobre a viabilidade dessa metodologia na transdução de células dendríticas para utilização em protocolos de imunização.

Finalmente, as DCs completamente maduras, ativadas, "carregadas" com os vários produtos antigênicos e, teoricamente, apresentando epítopos do HIV foram colocadas em cultura juntamente com linfócitos autólogos no intuito de avaliar o potencial de estimulação linfocitária dessas células e comparar a resposta imunológica desenvolvida frente aos diferentes produtos utilizados do HIV. Para isso, o co-cultivo foi realizado em duas partes: primeiramente, os linfócitos autólogos foram cultivados em contato com as células dendríticas ativadas durante 7 dias (estímulo primário) a fim de promover a seleção de linfócitos T HIV-específicos, uma vez que, após esse período, apenas aquelas células cujo TCR reconheceu o epítopo apresentado pelo HLA das DCs recebem estimulação suficiente para permanecerem vivos num ambiente de cultura livre de qualquer tipo de citocina ou fator de crescimento exógeno; os linfócitos que expressam outras combinações de TCR, por sua vez, entram em apoptose por falta de estimulação. Então, no sétimo dia, mais células dendríticas ativadas foram adicionadas a co-cultura (estímulo secundário) e 72 horas após esse segundo estímulo a ativação e proliferação dos linfócitos T específicos, bem como a produção de IFN $\gamma$ foi avaliada.

Observou-se que os linfócitos T de indivíduos previamente expostos ao HIV em contato com células dendríticas infectadas com HIV inativado (DC-HIV) ou pulsadas com a proteína p55Gag (DCp55) proliferaram significativamente mais que aqueles co-cultivados com DCs ativadas sem antígenos virais (DCm). Concomitantemente, esses linfócitos apresentavam maior expressão da molécula CD38, denotando ativação celular. No entanto, o mesmo padrão de ativação e resposta proliferativa foi observado pelos linfócitos dos indivíduos sadios não expostos ao HIV do grupo controle, ou seja, linfócitos que teoricamente nunca foram expostos a antígenos do HIV reconheceram DCs infectadas por vírus inativado ou pulsadas com p55Gag. É claro que o repertório das moléculas do TCR em humanos 
é enorme e haveria a chance de que alguns clones reconhecessem especificamente um epítopo de HIV. Porém, calcula-se que isso seja em torno de 1 em cada $10^{7}$ ou $10^{8}$ linfócitos e, num sistema in vitro, com um número limitado de células por poço de cultura pode-se supor que esse seja um evento quase que impossível de ocorrer. Ainda, dado a magnitude da resposta quantificada, é mais prudente hipotetizar que trata-se de resposta cruzada inespecífica. Ora, as DCs em cultura estão completamente ativadas, expressando altos índices de moléculas co-estimulatórias e secretando altos níveis de MIP-1 $\alpha$ (e possivelmente de IL-12 e TNF $\alpha$ ) e baixos níveis de IL-10. Além disso, nem todas as moléculas de HLA apresentam epítopos do HIV; grande parte delas estabilizou-se com antígenos próprios. Assim, dado esse quadro geral, altamente propício a ativação celular, é possível que os linfócitos tenham reconhecido epítopos próprios (ou em menor escala reconhecimento cruzado de epítopos virais) e, devido à abundância de outros sinais estimulatórios, induzidos a ativação e proliferação.

Outro ponto que pode ter influenciado os resultados obtidos foram os próprios ensaios empregados. A quantificação da expressão da glicoproteína CD38, por exemplo, pode ter levado a uma suposição errada sobre a ativação dos linfócitos, uma vez que vários autores citam que essa molécula pode ser encontrada em diversos tipos celulares em diferentes estágios do ciclo celular (DEAGLIO et al., 2001; JACKSON e BELL, 1990; MALAVASI et al., 2008; RAWSTRON, 2006). Talvez ensaios mais específicos como a expressão de segundo mensageiros intracelulares, fosforilação de proteínas ou mesmo secreção de citocinas (como discutido a seguir) poderiam ser mais adequados neste contexto de estimulação dos linfócitos.

Seguindo o mesmo padrão, os linfócitos dos pares discordantes estimulados pelas DC-HIV e DCp55 apresentaram produção e secreção de IFN $\gamma$ significativamente maiores que os estimulados por DCm. Porém, essa dosagem mostrou-se muito mais confiável em avaliar resposta de linfócitos $T$ específicos ao HIV que os ensaios anteriores, uma vez que, em nenhuma das condições de estimulação dos linfócitos dos indivíduos do grupo controle foram obtidas quantidades significativas dessa citocina. Porém, um revés pode ser apontado com relação aos resultados encontrados: a baixa porcentagem de linfócitos produtores de IFN $\gamma$ detectados pela técnica de citometria de fluxo (sempre menor que $1 \%$ ). $\mathrm{Na}$ verdade, esses valores estão em conformidade com resultados provenientes da 
literatura, porém quantificados pela técnica de ELISpot, que é mais sensível que o ensaio de citometria de fluxo e é considerado o padrão-ouro para detecção de IFN $\gamma$ em resposta a antígenos de HIV, porém apresenta a desvantagem de não avaliar separadamente as subpopulações de linfócitos. Dados de diversos estudos mostram variações de 40 a 10000 spots/milhão de células, isto é 0,004 a $1 \%$ de células produtoras (BOAZ et al., 2009; DUBEY et al., 2007; STREECK et al., 2009; SUN et al., 2003).

Assim, os resultados de produção de IFN $\gamma$, juntamente com os resultados de baixa produção de IL-10, permitem sugerir que as células dendríticas "carregadas" in vitro com antígenos do HIV são capazes de estimular os linfócitos $T$ no desenvolvimento de uma resposta anti-HIV eventualmente protetora. É importante ressaltar ainda que os linfócitos estimulados pelas DCs infectadas e transduzidas pelos vetores lentivirais construídos não proliferaram, não expressaram CD38 e também não produziram níveis maiores de IFN $\gamma$ do que os estimulados pela condição basal; corroborando a idéia de que houve falha na construção desses vetores e, portanto, até o momento, nem o plasmídeo pNL4-3 ${ }^{H S A}$ pol-env- ou a proteína DC-LAMP/Gag podem ser avaliadas quanto a sua capacidade imunogênica ou comparadas com os outros produtos antigênicos testados. De fato, os resultados aqui discutidos apontam uma direção promissora, porém alguns outros experimentos devem ser conduzidos quanto a avaliação da resposta imunológica dos linfócitos, e mesmo quanto a correta construção dos vetores virais, para então poder se chegar a uma conclusão sobre qual o melhor produto ou forma antigênica para estabelecimento de resposta imune anti-HIV abrangente e possivelmente protetora. 
Conchusão 


\section{CONCLUSÃO}

O presente estudo propôs avaliar metodologias alternativas de ativação de células dendríticas derivadas de monócitos humanos, utilizando diferentes produtos ou formas antigênicas do HIV, na tentativa de modular a apresentação antigênica dessas APCs

Os resultados obtidos permitem concluir que a obtenção de células dendríticas a partir de monócitos humanos, bem como os processos de maturação e ativação in vitro das mesmas, constitui metodologia relativamente simples e perfeitamente viável para sua utilização em protocolos de imunização. Ainda, observou-se que essas células são capazes de estimular in vitro linfócitos $T$ autólogos, induzindo ativação, proliferação e produção de IFN $\gamma$.

Além disso, tanto os subtipos virais inativados quanto a proteína p55Gag apresentaram-se como bons candidatos a antígeno alternativo em relação a proposta original utilizando HIV autólogo, ambos com vantagens e desvantagens. A p55Gag representa uma alternativa mais fácil, menos trabalhosa e principalmente mais barata, porém não oferece a variedade antigênica encontra no pool com diferentes subtipos do HIV, apesar deste ser quase tão dispendioso e caro de ser obtido quanto os vírus autólogos.

Entretanto, não foi possível concluir se a metodologia de vetores virais constitui protocolo adequado para inserção de DNA plasmidial em células dendríticas humanas. 

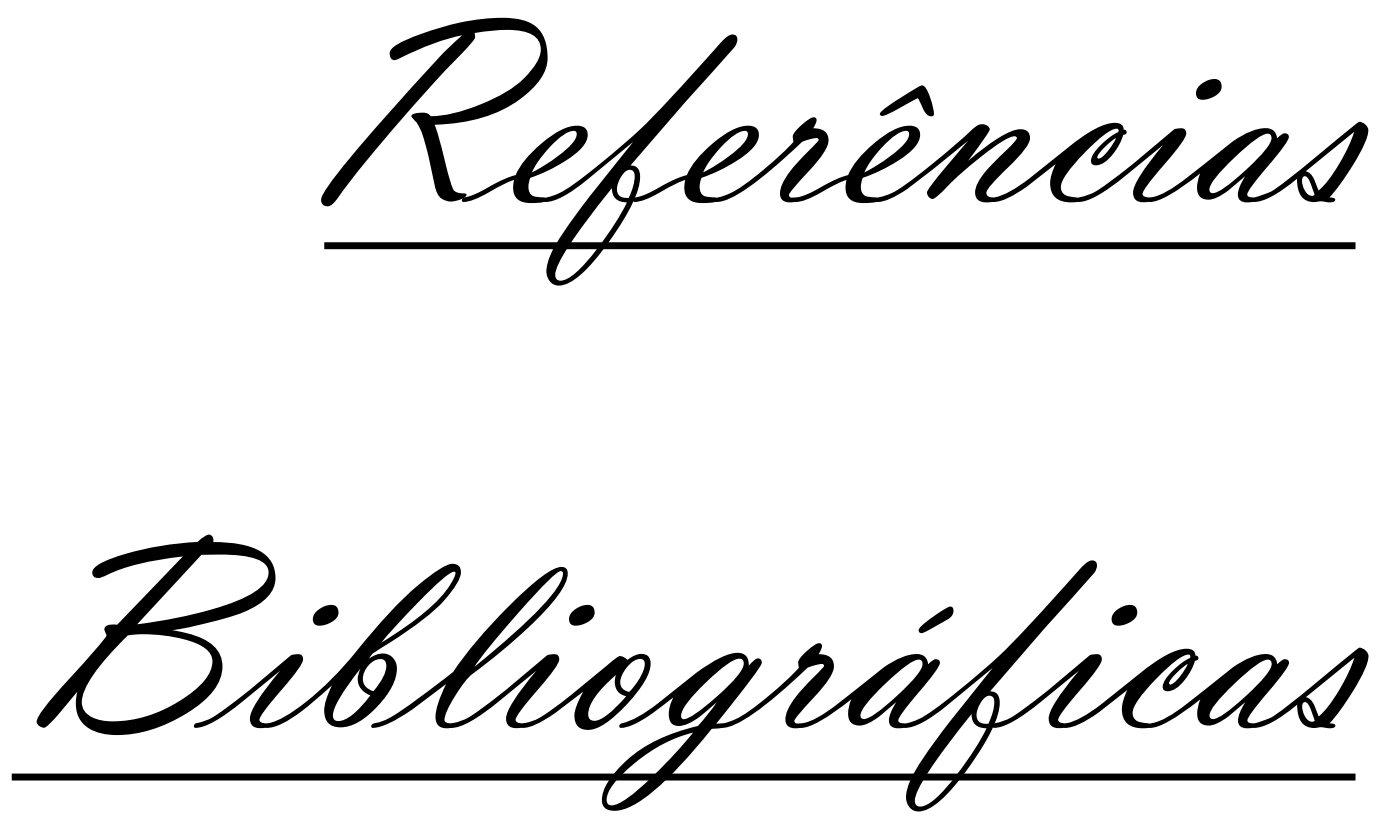
ANDRIEU, J. M.;LU, W. A dendritic cell-based vaccine for treating HIV infection: background and preliminary results. J. Intern. Med, v.261, n. 2, p. 123-131, 2007.

ARDAVIN, C., et al. Origin and differentiation of dendritic cells. Trends Immunol., v.22, n. 12, p. 691-700, 2001.

ARRUDA, L. B., et al. Dendritic cell-lysosomal-associated membrane protein (LAMP) and LAMP-1-HIV-1 gag chimeras have distinct cellular trafficking pathways and prime $\mathrm{T}$ and $\mathrm{B}$ cell responses to a diverse repertoire of epitopes. J. Immunol., v.177, n. 4, p. 2265-2275, 2006.

ARTHUR, L. O., et al. Cellular proteins bound to immunodeficiency viruses: implications for pathogenesis and vaccines. Science, v.258, n. 5090, p. 1935-1938, 1992.

BANCHEREAU, J.; STEINMAN R. M. Dendritic cells and the control of immunity. Nature, v.392, n. 6673, p. 245-252, 1998.

BAROUCH, D. H. Rational design of gene-based vaccines. J. Pathol., v.208, n. 2, p. 283-289, 2006.

BARRATT-BOYES, S. M.; ZIMMER, M. I.; HARSHYNE, L. Changes in dendritic cell migration and activation during SIV infection suggest a role in initial viral spread and eventual immunosuppression. J. Med. Primatol., v.31, n. 4-5, p. 186-193, 2002.

BARRE-SINOUSSI, F., et al. Isolation of a T-lymphotropic retrovirus from a patient at risk for acquired immune deficiency syndrome (AIDS). Science, v.220, n. 4599, p. 868-871, 1983.

BARRON, M. A., et al. Influence of plasma viremia on defects in number and immunophenotype of blood dendritic cell subsets in human immunodeficiency virus 1-infected individuals. J. Infect. Dis., v.187, n. 1, p. 26-37, 2003.

BARTH, A. S., et al. Lentiviral vectors bearing the cardiac promoter of the $\mathrm{Na}+-\mathrm{Ca}+$ exchanger report cardiogenic differentiation in stem cells. Mol. Ther., v.16, n. 5, p. 957-964, 2008.

BERBERICH, C., et al. Dendritic cell (DC)-based protection against an intracellular pathogen is dependent upon DC-derived IL-12 and can be induced by molecularly defined antigens. J. Immunol., v.170, n.6, p.3171-3179, 2003.

BERCHTOLD, S., et al. Cloning, recombinant expression and biochemical characterization of the murine CD83 molecule which is specifically upregulated during dendritic cell maturation. FEBS Lett., v.461, n. 3, p. 211-216, 1999.

BERTOLETTI, A., et al. Cytotoxic T cells from human immunodeficiency virus type 2infected patients frequently cross-react with different human immunodeficiency virus type 1 clades. J. Virol., v.72, n. 3, p. 2439-2448, 1998.

BETTS, M. R., et al. Characterization of functional and phenotypic changes in antiGag vaccine-induced $T$ cell responses and their role in protection after HIV-1 
infection. Proc. Natl. Acad. Sci. U. S. A., v.102, n. 12, p. 4512-4517, 2005.

BOAZ, M. J., et al. Concordant proficiency in measurement of T-cell immunity in human immunodeficiency virus vaccine clinical trials by peripheral blood mononuclear cell and enzyme-linked immunospot assays in laboratories from three continents. Clin. Vaccine Immunol., v.16, n. 2, p. 147-155, 2009.

BORRAS-BLASCO, J., et al. Adverse cutaneous reactions associated with the newest antiretroviral drugs in patients with human immunodeficiency virus infection. J. Antimicrob. Chemother., v.62, n. 5, p. 879-888, 2008.

BORROW, P., et al. Virus-specific CD8+ cytotoxic T-lymphocyte activity associated with control of viremia in primary human immunodeficiency virus type 1 infection. J. Virol., v.68, n. 9, p. 6103-6110, 1994.

BRECKPOT, K., et al. Lentivirally transduced dendritic cells as a tool for cancer immunotherapy. J. Gene Med., v.5, n. 8, p. 654-667, 2003.

BUCHBINDER, S. P., et al. Efficacy assessment of a cell-mediated immunity HIV-1 vaccine (the Step Study): a double-blind, randomised, placebo-controlled, test-ofconcept trial. Lancet, v.372, n. 9653, p. 1881-1893, 2008.

BUISSON, S., et al. Monocyte-derived dendritic cells from HIV type 1-infected individuals show reduced ability to stimulate $T$ cells and have altered production of interleukin (IL)-12 and IL-10. J. Infect. Dis., v.199, n. 12, p. 1862-1871, 2009.

BUSEYNE, F., et al. MHC-I-restricted presentation of HIV-1 virion antigens without viral replication. Nat. Med., v.7, n. 3, p. 344-349, 2001.

CARR, A. HIV protease inhibitor-related lipodystrophy syndrome. Clin. Infect. Dis., v.30 Suppl 2, n. p. S135-S142, 2000.

CHANG, C. C.; WRIGHT, A.; PUNNONEN, J. Monocyte-derived CD1a+ and CD1adendritic cell subsets differ in their cytokine production profiles, susceptibilities to transfection, and capacities to direct Th cell differentiation. J. Immunol., v.165, n. 7, p. 3584-3591, 2000.

CHEHIMI, J., et al. Persistent decreases in blood plasmacytoid dendritic cell number and function despite effective highly active antiretroviral therapy and increased blood myeloid dendritic cells in HIV-infected individuals. J. Immunol., v.168, n. 9, p. 47964801, 2002.

CHOUGNET, C., et al. Normal immune function of monocyte-derived dendritic cells from HIV-infected individuals: implications for immunotherapy. J. Immunol., v.163, n. 3, p. 1666-1673, 1999.

CONDON, C., et al. DNA-based immunization by in vivo transfection of dendritic cells. Nat. Med., v.2, n. 10, p. 1122-1128, 1996.

CONTI, L., et al. Immunomodulatory effects of the HIV-1 gp120 protein on antigen presenting cells: implications for AIDS pathogenesis. Immunobiology, v.209, n. 1-2, p. 99-115, 2004. 
D'OSTIANI, C. F., et al. Dendritic cells discriminate between yeasts and hyphae of the fungus Candida albicans: implications for initiation of $\mathrm{T}$ helper cell immunity in vitro and in vivo. J. Exp. Med., v.191, n.10, p.1661-1673, 2000.

DE ARRUDA, L. B., et al. DNA vaccine encoding human immunodeficiency virus-1 Gag, targeted to the major histocompatibility complex II compartment by lysosomalassociated membrane protein, elicits enhanced long-term memory response. Immunology, v.112, n. 1, p. 126-133, 2004.

DEAGLIO, S.; MEHTA, K.; MALAVASI, F. Human CD38: a (r)evolutionary story of enzymes and receptors. Leuk. Res., v.25, n. 1, p. 1-12, 2001.

DEMANGEL, C., et al. Protection against aerosol Mycobacterium tuberculosis infection using Mycobacterium bovis Bacillus Calmette Guérin-infected dendritic cells. Eur. J. Immunol., v.29, n.6, p.1972-1979, 1999.

DHODAPKAR, M. V.; STEINMAN, R. M. Antigen-bearing immature dendritic cells induce peptide-specific CD8(+) regulatory T cells in vivo in humans. Blood, v.100, $\mathrm{n}$. 1, p. 174-177, 2002.

DHODAPKAR, M. V., et al. Antigen-specific inhibition of effector T cell function in humans after injection of immature dendritic cells. J. Exp. Med., v.193, n. 2, p. 233238, 2001.

DONAGHY, $\mathrm{H}$., et al. Loss of blood CD11c(+) myeloid and CD11c(-) plasmacytoid dendritic cells in patients with HIV-1 infection correlates with HIV-1 RNA virus load. Blood, v.98, n. 8, p. 2574-2576, 2001.

DONAGHY, H.; STEBBING, J.; PATTERSON, S. Antigen presentation and the role of dendritic cells in HIV. Curr. Opin. Infect. Dis., v.17, n. 1, p. 1-6, 2004.

DUBEY, S., et al. Detection of HIV vaccine-induced cell-mediated immunity in HIVseronegative clinical trial participants using an optimized and validated enzymelinked immunospot assay. J. Acquir. Immune Defic. Syndr., v.45, n. 1, p. 20-27, 2007.

DUPERRIER, K., et al. Distinct subsets of dendritic cells resembling dermal DCs can be generated in vitro from monocytes, in the presence of different serum supplements. J. Immunol. Methods, v.238, n. 1-2, p. 119-131, 2000.

ESTCOURT, M. J.; MCMICHAEL, A. J.; HANKE, T. DNA vaccines against human immunodeficiency virus type 1. Immunol. Rev., v.199, n. p. 144-155, 2004.

FELGNER, P. L., et al. Lipofection: a highly efficient, lipid-mediated DNA transfection procedure. Proc. Natl. Acad. Sci. U. S. A., v.84, n.21, p.7413-7417, 1987.

FINKE, J. S., et al. Dendritic cell numbers in the blood of HIV-1 infected patients before and after changes in antiretroviral therapy. J. Clin. Immunol., v.24, n. 6, p. 647-652, 2004.

FLOHÉ, S. B., et al. Antigen pulsed epidermal Langerhans cells protect susceptible mice from infection with the intracellular parasite Leishmania major. Eur. J. 
Immunol., v.28, n.11, p.3800-3811, 1998.

FONTAINE, J., et al. HIV infection affects blood myeloid dendritic cells after successful therapy and despite nonprogressing clinical disease. J. Infect. Dis., v.199, n. 7, p. 1007-1018, 2009.

FRIEDRICH, T. C., et al. Subdominant CD8+ T-cell responses are involved in durable control of AIDS virus replication. J. Virol., v.81, n. 7, p. 3465-3476, 2007.

GALLO, R. C., et al. Isolation of human T-cell leukemia virus in acquired immune deficiency syndrome (AIDS). Science, v.220, n. 4599, p. 865-867, 1983.

GIRARD, M. P.; OSMANOV, S. K.; KIENY, M. P. A review of vaccine research and development: the human immunodeficiency virus (HIV). Vaccine, v.24, n. 19, p. 4062-4081, 2006.

GOTTLIEB, M. S., et al. Pneumocystis carinii pneumonia and mucosal candidiasis in previously healthy homosexual men: evidence of a new acquired cellular immunodeficiency. N. Engl. J. Med., v.305, n. 24, p. 1425-1431, 1981.

GRASSI, F., et al. Depletion in blood CD11c-positive dendritic cells from HIV-infected patients. Aids, v.13, n. 7, p. 759-766, 1999.

GUERMONPREZ, P., et al. Antigen presentation and T cell stimulation by dendritic cells. Annu. Rev. Immunol., v.20, p. 621-667, 2002.

HATTORI, Y., et al. Efficient gene transfer into macrophages and dendritic cells by in vivo gene delivery with mannosylated lipoplex via the intraperitoneal route. $\mathbf{J}$. Pharmacol. Exp. Ther., v.318, n. 2, p. 828-834, 2006.

HAWIGER, D., et al. Dendritic cells induce peripheral T cell unresponsiveness under steady state conditions in vivo. J. Exp. Med., v.194, n. 6, p. 769-779, 2001.

HE, Y., et al. Immunization with lentiviral vector-transduced dendritic cells induces strong and long-lasting $\mathrm{T}$ cell responses and therapeutic immunity. J. Immunol., v.174, n. 6, p. 3808-17, 2005.

HENGEL, R. L.; WATTS, N. B.; LENNOX, J. L. Benign symmetric lipomatosis associated with protease inhibitors. Lancet, v.350, n. 9091, p. 1596, 1997.

HOGAN, C. M.; HAMMER, S. M. Host determinants in HIV infection and disease. Part 1: cellular and humoral immune responses. Ann. Intern. Med., v.134, n. 9, p. 761-776, 2001.

HOWARTH, M.; ELLIOTT, T. The processing of antigens delivered as DNA vaccines. Immunol. Rev., v.199, p. 27-39, 2004.

HUANG, S., et al. Deficiency of HIV-Gag-specific T cells in early childhood correlates with poor viral containment. J. Immunol., v.181, n. 11, p. 8103-8111, 2008.

IAVI - INTERNATIONAL AIDS VACCINE INITIATIVE. AIDS vaccine blueprint 2008: a challenge to the field, a roadmap to progress. New York: IAVI, 2008. 102 p. 
JACKSON, D. G.; BELL, J. I. Isolation of a cDNA encoding the human CD38 (T10) molecule, a cell surface glycoprotein with an unusual discontinuous pattern of expression during lymphocyte differentiation. J. Immunol., v.144, n. 7, p. 2811-2815, 1990.

JIN, Y., et al. Antigen presentation and immune regulatory capacity of immature and mature-enriched antigen presenting (dendritic) cells derived from human bone marrow. Hum. Immunol., v.65, n. 2, p. 93-103, 2004.

KAKUDA, T. N. Pharmacology of nucleoside and nucleotide reverse transcriptase inhibitor-induced mitochondrial toxicity. Clin. Ther., v.22, n. 6, p. 685-708, 2000.

KASLOW, D. C. A potential disruptive technology in vaccine development: genebased vaccines and their application to infectious diseases. Trans. R. Soc. Trop. Med. Hyg., v.98, n. 10, p. 593-601, 2004.

KOUP, R. A., et al. Temporal association of cellular immune responses with the initial control of viremia in primary human immunodeficiency virus type 1 syndrome. J. Virol., v.68, n. 7, p. 4650-4655, 1994.

LANDI, A.; BABIUK, L. A.; VAN DRUNEN LITTEL-VAN DEN HURK, S. High transfection efficiency, gene expression, and viability of monocyte-derived human dendritic cells after nonviral gene transfer. J. Leukoc. Biol., v.82, n. 4, p. 849-860, 2007.

LISZIEWICZ, J., et al. Control of viral rebound through therapeutic immunization with DermaVir. Aids, v.19, n. 1, p. 35-43, 2005.

LOPES, A. R., et al. Greater CD8+ TCR heterogeneity and functional flexibility in HIV-2 compared to HIV-1 infection. J. Immunol., v.171, n. 1, p. 307-316, 2003.

LOS ALAMOS NATIONAL LABORATORY. The circulating recombinat forms (CRFs). Disponível em: <http://www.hiv.lanl.gov>. Acesso em: 16 jan. 2010.

LOS ALAMOS NATIONAL LABORATORY. HIV sequence compendium 2009. New Mexico: Theoretical Biology and Biophysics, 2009. 436 p.

LU, W., et al. Therapeutic dendritic-cell vaccine for simian AIDS. Nat. Med., v.9, n. 1, p. 27-32, 2003.

LU, W., et al. Therapeutic dendritic-cell vaccine for chronic HIV-1 infection. Nat. Med., v.10, n. 12, p. 1359-1365, 2004

LUDEWIG, B., et al. Dendritic cells efficiently induce protective antiviral immunity. J. Virol., v.72, n.5, p. 3812-3818, 1998.

LUO, J., et al. Treatment of cancer with a novel dual-targeted conditionally replicative adenovirus armed with mda-7/IL-24 gene. Clin. Cancer. Res., v.14, n. 8, p. 24502457, 2008.

LUTZ, M. B.; SCHULER, G. Immature, semi-mature and fully mature dendritic cells: which signals induce tolerance or immunity? Trends Immunol., v.23, n. 9, p. 445- 
449, 2002.

MACGREGOR, R. R., et al. Plasmid vaccination of stable HIV-positive subjects on antiviral treatment results in enhanced CD8 T-cell immunity and increased control of viral "blips". Vaccine, v.23, n. 17-18, p. 2066-2073, 2005.

MADGE, S., et al. Lipodystrophy in patients naive to HIV protease inhibitors. Aids, v.13, n. 6, p. 735-737, 1999.

MALAVASI, F., et al. Evolution and function of the ADP ribosyl cyclase/CD38 gene family in physiology and pathology. Physiol. Rev., v.88, n. 3, p. 841-886, 2008.

MARQUES, JR. E. T., et al. HIV-1 p55Gag encoded in the lysosome-associated membrane protein-1 as a DNA plasmid vaccine chimera is highly expressed, traffics to the major histocompatibility class II compartment, and elicits enhanced immune responses. J. Biol. Chem., v.278, n. 39, p. 37926-37936, 2003.

MASTRO, T. D.; KITAYAPORN, D. HIV type 1 transmission probabilities: estimates from epidemiological studies. AIDS Res. Hum. Retroviruses, v.14 Suppl 3, p. S223S227, 1998.

MASUR, H., et al. An outbreak of community-acquired Pneumocystis carinii pneumonia: initial manifestation of cellular immune dysfunction. N. Engl. J. Med., v.305, n. 24, p. 1431-1438, 1981.

MATLOUBIAN, M.; CONCEPCION, R. J.; AHMED, R. CD4+ T cells are required to sustain CD8+ cytotoxic T-cell responses during chronic viral infection. J. Virol., v.68, n. 12 , p. 8056-8063, 1994.

MBOW, M. L. et al. Borrelia burgdorferi-pulsed dendritic cells induce a protective immune response against tick-transmitted spirochetes. Infect. Immun., v.65, n.8, p.3386-3390, 1997.

MCKENNA, K.; BEIGNON, A. S.; BHARDWAJ, N. Plasmacytoid dendritic cells: linking innate and adaptive immunity. J. Virol., v.79, n. 1, p. 17-27, 2005.

MCKINNEY, D. M., et al. Recognition of variant HIV-1 epitopes from diverse viral subtypes by vaccine-induced CTL. J. Immunol., v.173, n. 3, p. 1941-1950, 2004.

MINISTÉRIO DA SAÚDE. AIDS Bol. Epidem. 1998. Disponível em: <http://www.aids.gov.br>. Acesso em: 16 jan. 2010.

MINISTÉRIO DA SAÚDE. AIDS Bol. Epidem. 2005. Disponível em: $<$ http://www.aids.gov.br>. Acesso em: 16 jan. 2010.

MINISTÉRIO DA SAÚDE. Recomendações para terapia antirretroviral em adultos e adolescentes infectados pelo HIV 2006. Disponível em: $<$ http://www.aids.gov.br>. Acesso em: 16 jan. 2010.

MINISTÉRIO DA SAÚDE. AIDS Bol. Epidem. 2008. Disponível em: $<$ http://www.aids.gov.br>. Acesso em: 16 jan. 2010. 
MOSS, R. B., et al. HIV-specific immunity during structured antiviral drug treatment interruption. Vaccine, v.21, n. 11-12, p. 1066-1071, 2003.

OGG, G. S., et al. Quantitation of HIV-1-specific cytotoxic T lymphocytes and plasma load of viral RNA. Science, v.279, n. 5359, p. 2103-2106, 1998.

PACANOWSKI, J., et al. Reduced blood CD123+ (lymphoid) and CD11C+ (myeloid) dendritic cell numbers in primary HIV-1 infection. Blood, v.98, n. 10, p. 3016-3021, 2001.

PIOT, P. The science of AIDS: a tale of two worlds. Science, v.280, n. 5371, p. 1844-1845, 1998.

PRICE, D. A., et al. Public clonotype usage identifies protective Gag-specific CD8+ T cell responses in SIV infection. J. Exp. Med., v.206, n. 4, p. 923-936, 2009.

RAJCANI, J.; MOSKO, T.; REZUCHOVA, I. Current developments in viral DNA vaccines: shall they solve the unsolved? Rev. Med. Virol., v.15, n. 5, p. 303-325, 2005.

RAWSTRON, A. C. Immunophenotyping of plasma cells. Curr. Protoc. Cytom., Chapter 6, Unit 6.23, 2006.

RINALDO, JR., C. R.; PIAZZA, P. Virus infection of dendritic cells: portal for host invasion and host defense. Trends Microbiol., v.12, n. 7, p. 337-345, 2004.

ROLLAND, M., et al. Broad and Gag-biased HIV-1 epitope repertoires are associated with lower viral loads. PLoS One, v.3, n. 1, p. e1424, 2008.

ROMANI, N., et al. Generation of mature dendritic cells from human blood. An improved method with special regard to clinical applicability. J. Immunol. Methods, v.196, n. 2, p. 137-151, 1996.

ROSSIO, J. L., et al. Inactivation of human immunodeficiency virus type 1 infectivity with preservation of conformational and functional integrity of virion surface proteins. J. Virol., v.72, n. 10, p. 7992-8001, 1998.

SACHA, J. B., et al. Gag-specific CD8+ T lymphocytes recognize infected cells before AIDS-virus integration and viral protein expression. J. Immunol., v.178, n. 5, p. 2746-2754, 2007.

SALLUSTO, F.; LANZAVECCHIA, A. Efficient presentation of soluble antigen by cultured human dendritic cells is maintained by granulocyte/macrophage colonystimulating factor plus interleukin 4 and downregulated by tumor necrosis factor alpha. J. Exp. Med., v.179, n. 4, p. 1109-1118, 1994.

SAPP, M., et al. Dendritic cells generated from blood monocytes of HIV-1 patients are not infected and act as competent antigen presenting cells eliciting potent T-cell responses. Immunol. Lett., v.66, n. 1-3, p. 121-128, 1999.

SCHÖN, E, et al. Dendritic cell vaccination protects mice against lethality caused by genital herpes simplex virus type 2 infection. J. Reprod. Immunol., v.50, n.2, p.87- 
104, 2001.

SCHULER, G.; SCHULER-THURNER, B.; STEINMAN R. M. The use of dendritic cells in cancer immunotherapy. Curr. Opin. Immunol., v.15, n.2, p.138-147, 2003.

SERWANGA, J., et al. Host HLA B*allele-associated multi-clade Gag T-cell recognition correlates with slow HIV-1 disease progression in antiretroviral therapynaive Ugandans. PLoS One, v.4, n. 1, p. e4188, 2009.

SHEETS, R. L., et al. Toxicological safety evaluation of DNA plasmid vaccines against HIV-1, Ebola, Severe Acute Respiratory Syndrome, or West Nile virus is similar despite differing plasmid backbones or gene-inserts. Toxicol. Sci., v.91, n. 2, p. 620-630, 2006.

SHORTMAN, K.; LIU, Y. J. Mouse and human dendritic cell subtypes. Nat. Rev. Immunol., v.2, n. 3, p. 151-161, 2002.

SIEGAL, F. P., et al. The nature of the principal type 1 interferon-producing cells in human blood. Science, v.284, n. 5421, p. 1835-1837, 1999.

STEINBRINK, K., et al. Induction of tolerance by IL-10-treated dendritic cells. J. Immunol., v.159, n. 10, p. 4772-4780, 1997.

STEINMAN, R. M. Dendritic cells and the control of immunity: enhancing the efficiency of antigen presentation. Mt. Sinai J. Med., v.68, n. 3, p. 160-166, 2001.

STEINMAN, R. M.; HEMMI, H. Dendritic cells: translating innate to adaptive immunity. Curr. Top. Microbiol. Immunol., v.311, n. p. 17-58, 2006.

STREECK, H.; FRAHM, N.; WALKER, B. D. The role of IFN-gamma Elispot assay in HIV vaccine research. Nat. Protoc., v.4, n. 4, p. 461-469, 2009.

SUN, Y., et al. A systematic comparison of methods to measure HIV-1 specific CD8 T cells. J. Immunol. Methods, v.272, n. 1-2, p. 23-34, 2003.

SUY, A., et al. Immunological profile of heterosexual highly HIV-exposed uninfected individuals: predominant role of CD4 and CD8 T-cell activation. J. Infect. Dis., v.196, n. 8, p. 1191-1201, 2007.

TURVILLE, S. G., et al. Diversity of receptors binding HIV on dendritic cell subsets. Nat. Immunol., v.3, n. 10, p. 975-983, 2002.

UNAIDS. Report on the global AIDS epidemic 2006. Disponível em: <http://unaids.org>. Acesso em: 16 jan. 2010.

UNAIDS. Report on the global AIDS epidemic 2008. Disponível em: <http://unaids.org>. Acesso em: 16 jan. 2010.

VAN BAALEN, C. A., et al. Kinetics of antiviral activity by human immunodeficiency virus type 1-specific cytotoxic $T$ lymphocytes (CTL) and rapid selection of $C T L$ escape virus in vitro. J. Virol., v.72, n. 8, p. 6851-6857, 1998. 
VAN BAALEN, C. A., et al. Impact of antigen expression kinetics on the effectiveness of HIV-specific cytotoxic T lymphocytes. Eur. J. Immunol., v.32, n. 9, p. 2644-2652, 2002.

WALKER, C. M., et al. CD8+ lymphocytes can control HIV infection in vitro by suppressing virus replication. Science, v.234, n. 4783, p. 1563-1566, 1986.

WILSON, N. S.; EL-SUKKARI, D.; VILLADANGOS, J. A. Dendritic cells constitutively present self antigens in their immature state in vivo and regulate antigen presentation by controlling the rates of MHC class II synthesis and endocytosis. Blood, v.103, n. 6, p. 2187-2195, 2004.

WINGARD, J. B.; ANDERSON, B.; WEISSMAN, D. Induction of HIV-specific T and B cell responses with a replicating and conditionally infectious lentiviral vaccine. Eur. J. Immunol., v.38, n. 5, p. 1310-1320, 2008.

XIA, C. Q.; KAO, K. J. Heparin induces differentiation of CD1a+ dendritic cells from monocytes: phenotypic and functional characterization. J. Immunol., v.168, n. 3, p. 1131-1138, 2002.

YANG, O. O., et al. Impacts of avidity and specificity on the antiviral efficiency of HIV1-specific CTL. J. Immunol., v.171, n. 7, p. 3718-3724, 2003.

YANG, Y., et al. Inhibition of West Nile Virus replication by retrovirus-delivered small interfering RNA in human neuroblastoma cells. J. Med. Virol., v.80, n. 5, p. 930-936, 2008.

ZHOU, L. J.; TEDDER, T. F. CD14+ blood monocytes can differentiate into functionally mature CD83+ dendritic cells. Proc. Natl. Acad. Sci. U. S. A., v.93, n. 6, p. 2588-2592, 1996.

ZHDANOV, R. I.; PODOBED, O. V.; VLASSOV, V. V. Cationic lipid-DNA complexes - lipoplexes - for gene transfer and therapy. Bioelectrochemistry, v.58, n.1, p.5364, 2002. 